\title{
Impact of Sprinklers on the Fire Hazard in Dormitories: Day Room Fire Experiments
}

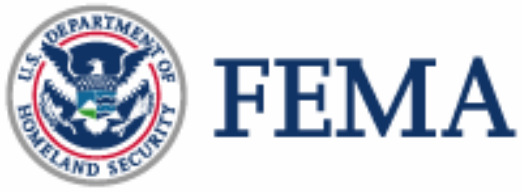

Sponsored in part by Department of Homeland Security Federal Emergency Management Agency United States Fire Administration 


\section{Impact of Sprinklers on the Fire Hazard in Dormitories: Day Room Fire Experiments}

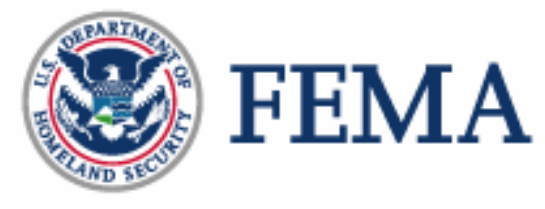

Department of Homeland Security

Tom Ridge, Secretary

Federal Emergency Management Agency

Michael D. Brown, Under Secretary of Emergency

Preparedness and Response

United States Fire Administration

R. David Paulison, Administrator

\author{
Daniel Madrzykowski \\ David W. Stroup \\ William D. Walton \\ Fire Research Division \\ Building and Fire Research Laboratory \\ National Institute of Standards and Technology \\ Gaithersburg, MD 20899-8661
}

June 2004

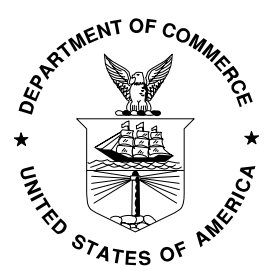

U.S. Department of Commerce Donald L. Evans, Secretary Technology Administration Phillip J. Bond, Under Secretary for Technology National Institute of Standards and Technology Arden L. Bement, Jr., Director 


\section{TABLE OF CONTENTS}

Page

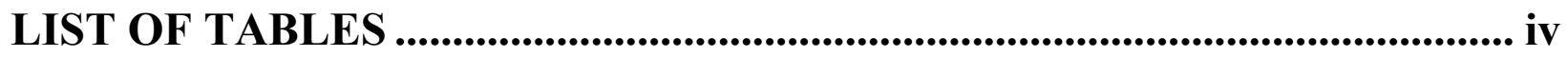

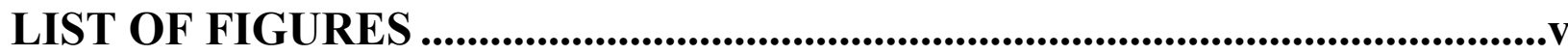

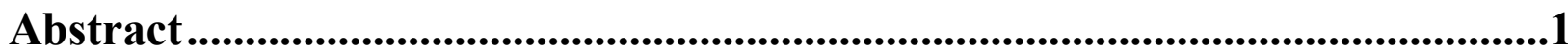

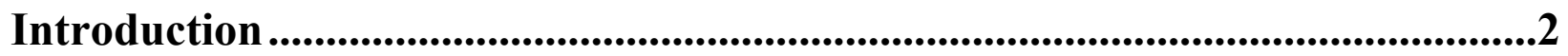

Experimental Configuration ..................................................................................3

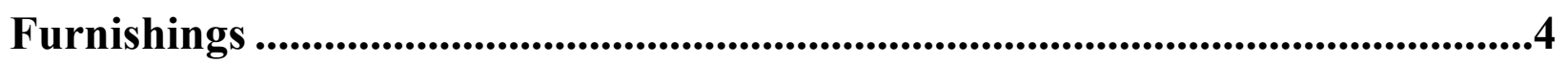

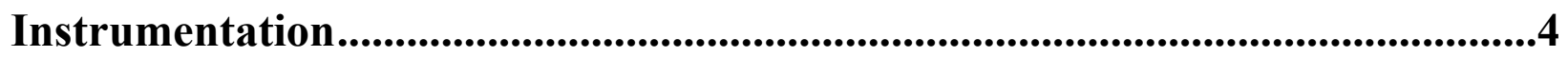

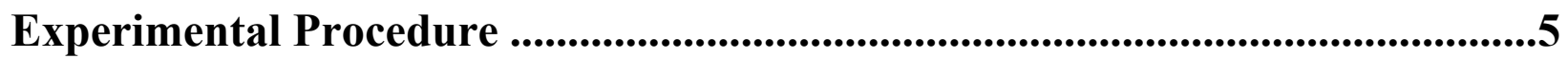

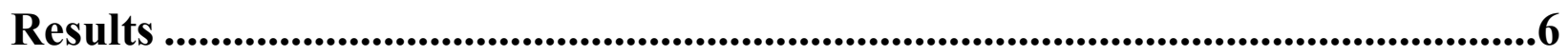

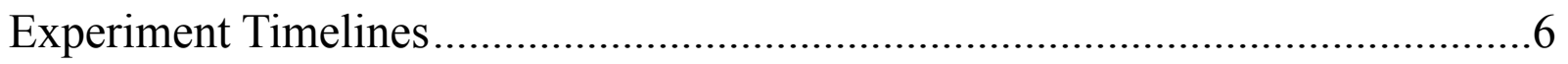

Smoke Alarm and Sprinkler Activation Times .................................................... 6

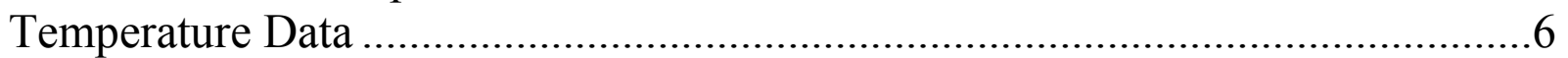

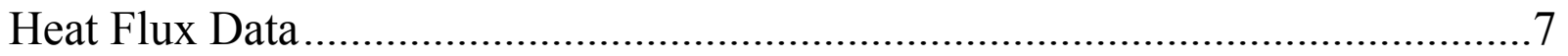

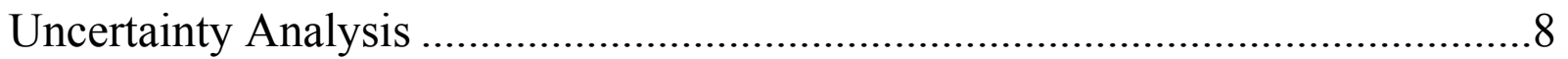

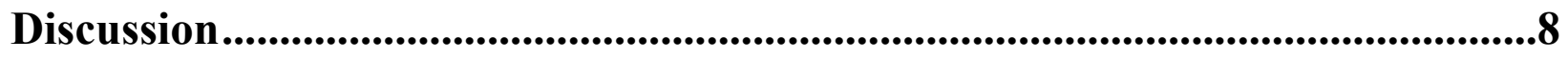

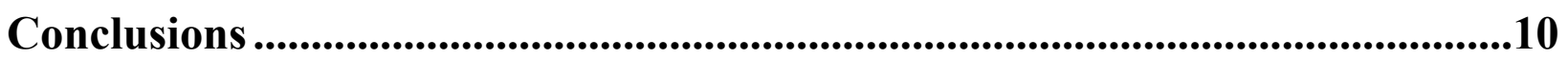

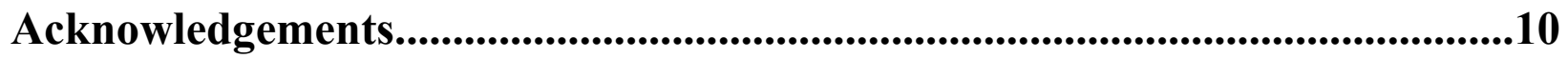

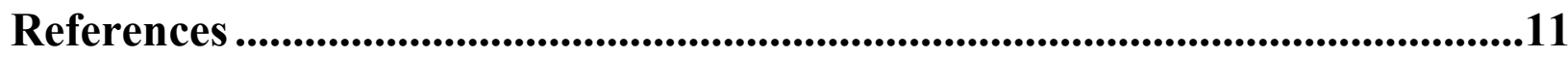




\section{LIST OF TABLES}

Table 1. Thermocouple Array and Smoke Alarm Location ................................................12

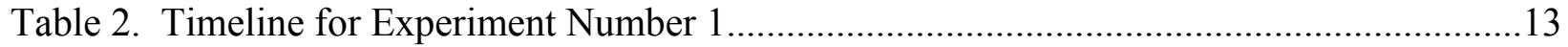

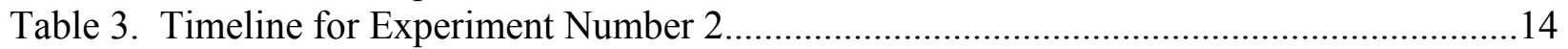

Table 4. Timeline for Experiment Number 3 ................................................................15

Table 5. Day Room Experiment 1, Smoke Alarm Activation and Sprinkler Activation Times...16

Table 6. Day Room Experiment 2, Smoke Alarm Activation Times .......................................16

Table 7. Day Room Experiment 3, Smoke Alarm Activation Times .......................................16

Table 8. Estimated Uncertainty in Full Scale Experimental Data .........................................17 


\section{LIST OF FIGURES}

Figure 1. Photograph of dormitory building, similar to the test structure. .................................18

Figure 2. Arrangement of the dormitory building, $1^{\text {st }}$ floor......................................................

Figure 3. Plan view of Day Room with sprinkler locations.......................................................20

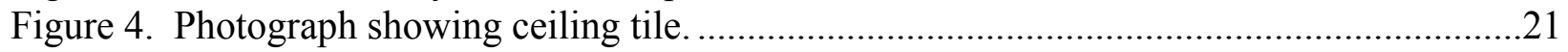

Figure 5. Photograph of the type of sofa used for ignition in all of the experiments and used as "target" sofas in experiments 2 and 3..................................................................................22

Figure 6. Photograph showing the fuel arrangement for the day room in experiment 1 ..............23

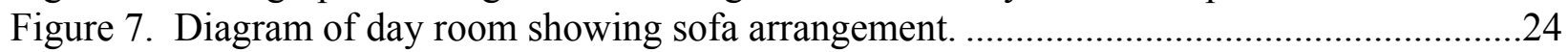

Figure 8. Photograph showing dayroom arrangement for experiment 2, with sofas, bulletin board

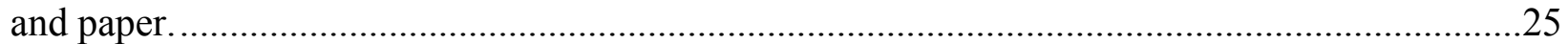

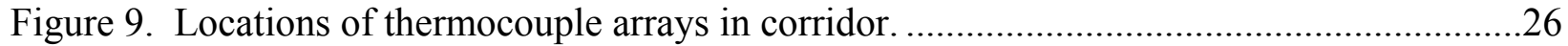

Figure 10. Diagram with instrumentation locations identified. ................................................27

Figure 11. Diagram with instrumentation locations identified in day room area. .......................28

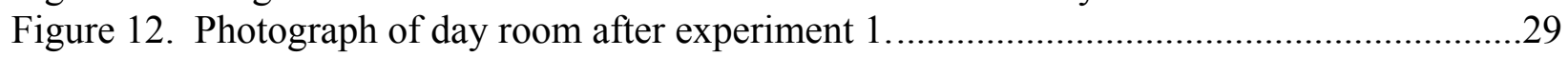

Figure 13. Photograph showing the day room after experiment 2............................................30

Figure 14. Photograph showing the ignition sofa after experiment 3 .......................................

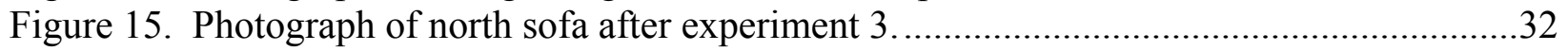

Figure 16. Photograph of corridor from the west approaching day room on right.......................33

Figure 17 Experiment 1, corridor temperatures, TC array 1........................................................

Figure 18 Experiment 1, corridor temperatures, TC array 2 .......................................................35

Figure 19 Experiment 1, corridor temperatures, TC array 3 .......................................................

Figure 20 Experiment 1, corridor temperatures, TC array 4........................................................

Figure 21 Experiment 1, corridor temperatures, TC array 5 ....................................................38

Figure 22 Experiment 1, corridor temperatures, TC array 6......................................................39

Figure 23 Experiment 1, dayroom temperatures, west side near ignition, TC array 7................40

Figure 24 Experiment 2, dayroom temperatures, east side, TC array 8..................................41

Figure 25 Experiment 1, corridor temperatures, TC array 9.....................................................42

Figure 26 Experiment 1, corridor temperatures, TC array 10...................................................43

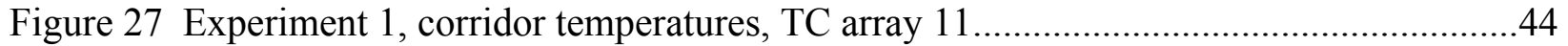

Figure 28 Experiment 1, corridor temperatures, TC array 12..................................................45

Figure 29 Experiment 2, corridor temperatures, TC array 1.....................................................46

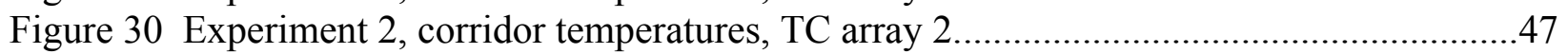

Figure 31 Experiment 2, corridor temperatures, TC array 3 …..................................................48

Figure 32 Experiment 2, corridor temperatures, TC array 4 .................................................49

Figure 33 Experiment 2, corridor temperatures, TC array 5 .................................................5

Figure 34 Experiment 2, corridor temperatures, TC array 6 ..................................................

Figure 35 Experiment 2, day room temperatures, west side near ignition, TC array 7 ...............52

Figure 36 Experiment 2, dayroom temperature, east side, TC array 8 .......................................53

Figure 37 Experiment 2, corridor temperature, TC array 9.....................................................54

Figure 38 Experiment 2, corridor temperatures, TC array 10....................................................5

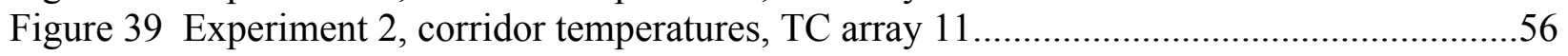


Figure 40 Experiment 2, corridor temperatures, TC array 12..................................................57

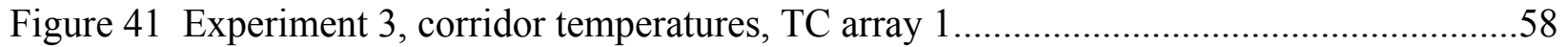

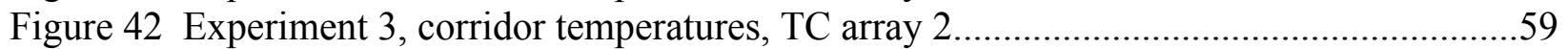

Figure 43 Experiment 3, corridor temperatures, TC array 3 ...................................................6

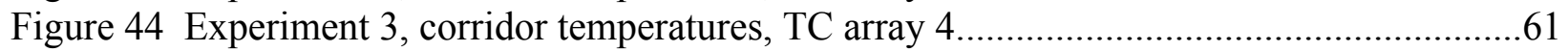

Figure 45 Experiment 3, corridor temperatures, TC array 5.................................................62

Figure 46 Experiment 3, corridor temperatures, TC array 6 ...................................................63

Figure 47 Experiment 3, dayroom temperatures west side near ignition, TC array $7 \ldots \ldots \ldots \ldots \ldots 64$

Figure 48 Experiment 3, dayroom temperatures, east side, TC array 8..................................65

Figure 49 Experiment 3, corridor temperatures, TC array 9 ...................................................66

Figure 50 Experiment 3, corridor temperatures, TC array 10...............................................67

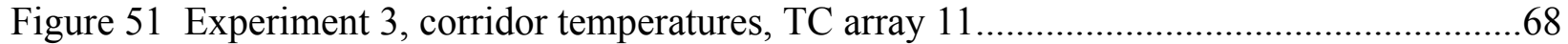

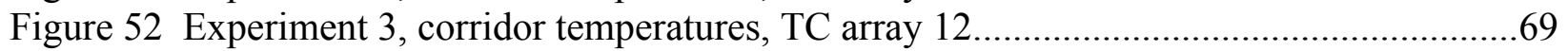

Figure 53 Experiment 2, total heat flux measured adjacent to TC array $6 \ldots \ldots \ldots \ldots \ldots \ldots \ldots \ldots \ldots \ldots \ldots \ldots . . . .70$

Figure 54 Experiment 2, total heat flux measured adjacent to TC array 5.................................71

Figure 55 Experiment 2, total heat flux measured adjacent to TC array 4................................72

Figure 56 Experiment 3, total heat flux measured adjacent to TC array $6 \ldots \ldots \ldots \ldots \ldots \ldots \ldots \ldots \ldots \ldots \ldots . . .73$

Figure 57 Experiment 3, total heat flux measured adjacent to TC array 5..................................74

Figure 58 Experiment 3, total heat flux measured adjacent to TC array 4....................................75

Figure 59 Experiment 1, temperatures in West Corridor at $.61 \mathrm{~m}$ below ceiling...........................76

Figure 60 Experiment 1, temperatures in East Corridor at $.61 \mathrm{~m}$ below ceiling. ............................77

Figure 61 Experiment 2, temperatures in West Corridor at $.61 \mathrm{~m}$ below ceiling...........................78

Figure 62 Experiment 2, temperatures in East Corridor at $.61 \mathrm{~m}$ below ceiling. ............................79

Figure 63 Experiment 3, temperatures in West Corridor at $.61 \mathrm{~m}$ below ceiling..........................80

Figure 64 Experiment 3, temperatures in East Corridor at $.61 \mathrm{~m}$ below ceiling. .........................81

Figure 65. Day Room temperature comparison for experiment 1,2, and 3at $0.61 \mathrm{~m}$ below the

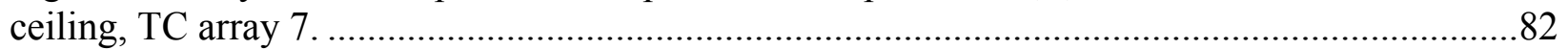




\title{
Impact of Sprinklers on the Fire Hazard in Dormitories: Day Room Fire Experiments
}

\author{
Daniel Madrzykowski, David W. Stroup, and William D. Walton \\ Building and Fire Research Laboratory \\ National Institute of Standards and Technology
}

\begin{abstract}
As part of a U.S. Fire Administration (USFA) initiative to improve fire safety in college housing, the National Institute of Standards and Technology (NIST) conducted two series of full-scale fire experiments in abandoned dormitory buildings. The objective of the study is to compare the levels of hazard created by room fires in a dormitory building with and without automatic fire sprinklers in the room of fire origin.

One series of experiments was conducted with the fires initiated in a dormitory sleeping room. These experiments were conducted by NIST in cooperation with the University of Arkansas and the Fayetteville Fire Department. The results of these experiments will be provided in a separate report.

This report describes a series of experiments where fires are initiated in a day room area open to the corridor of the dormitory. These experiments were conducted by NIST in cooperation with the Myrtle Beach Air Force Base Redevelopment Authority, the Myrtle Beach Fire Department, and the Bureau of Alcohol, Tobacco and Firearms (ATF).

This paper will provide a description of the experimental conditions including a description of the building construction, the fuel load in the day rooms, and the location of the instrumentation used to measure temperature and heat flux in the day room and the adjacent corridor. Smoke alarm activation and sprinkler activation times are also reported. The results from the experiments comparing the sprinklered and non-sprinklered day room are presented. The results from these experiments demonstrate the life safety benefits of smoke alarms and automatic fire sprinkler systems in college dormitories.
\end{abstract}

For further information on the USFA College Campus Fire Safety Program contact: www.usfa.fema.gov/publications.

\section{Key Words:}

corridor tests; dormitories; fire data; heat flux; large scale fire tests; sprinklers; temperature measurements 


\section{Introduction}

Each year there are approximately 1,300 documented fires in school and college dormitories in the United States [1]. Tragic fatal fires occur in these occupancies every year [2]. Buildings with an automatic sprinkler system have had excellent fire safety records. The chances of a fire causing or resulting in a fatality are significantly reduced with automatic fire sprinklers installed [3]. Yet the majority of the dormitories in this country, where a fire has occurred, did not have an automatic sprinkler system installed [3].

The U.S. Fire Administration (USFA) has made a commitment to increase the level of knowledge that campus officials and students have about the importance of sprinklers as part of their campus fire safety program. Several fire events in campus housing over the past 10 years have provided the motivation for this program. During the period from 1994 to 2000, 27 students died and 94 students were injured in campus housing fires [2]. The most common area of origin is a sleeping room, which accounts for almost $25 \%$ of the fires. Approximately $22 \%$ of the fires originate in hallways, corridors and lounge areas [2]. Paper is the leading material ignited in dormitory fires, accounting for approximately $32 \%[1,2]$ of the fires. "One- third of the dormitory fires are reported as arson (incendiary/suspicious)" and this is the leading reported cause of dormitory fires [1].

As part of the U.S. Fire Administration (USFA) initiative to improve fire safety in college housing, the National Institute of Standards and Technology (NIST) conducted two series of fullscale fire experiments in abandoned dormitory buildings. The objective of the study is to compare the levels of hazard created by room fires in a dormitory building with and without automatic fire sprinklers in the room of fire origin.

Based on the fire incident data, one series of experiments was designed with the fires starting in a dormitory sleeping room. These experiments were conducted by NIST in cooperation with the University of Arkansas and the Fayetteville Fire Department. The results of these experiments will be provided in a separate report.

The series of experiments, presented in this report, were designed with the fires starting in a day room or lounge area open to the corridor of the dormitory. These experiments were conducted by NIST in cooperation with the Myrtle Beach Air Force Base Redevelopment Authority, the Myrtle Beach Fire Department, and the Bureau of Alcohol, Tobacco and Firearms (ATF).

This paper documents experiments conducted to examine the fire development, the spread of hot gases down the corridors, and the effectiveness of an automatic sprinkler system in suppressing the fire. Three fire experiments were conducted: 1) sprinklered, 2) un-sprinklered with limited ventilation, and 3) un-sprinklered with increased ventilation. The experiments were conducted in an abandoned dormitory building in Myrtle Beach, SC. The 3-story, concrete, building was configured with a day room centrally located on each floor. 


\section{Experimental Configuration}

The experiments were conducted on the first floor of a three-story building. A photograph of a building similar to the building used for the experiments is shown in Figure 1. The building was formerly used as a military dormitory. The building construction consisted of poured concrete floor and ceiling deck with concrete block walls. The vertical distance between the floor and the concrete ceiling was $2.60 \mathrm{~m}$ ( $8 \mathrm{ft} 6 \mathrm{in})$. No floor covering was installed. The building was made available to NIST by agreement with the Myrtle Beach Air Force Base Redevelopment Authority.

The test area consisted of a corridor down the center of the first floor and a day room area which was located near the center of the building on the south side of the corridor, see Figure 2. The

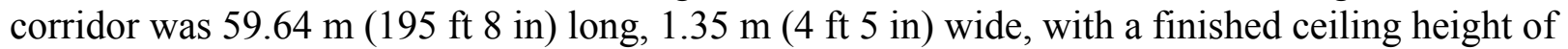
$2.08 \mathrm{~m}$ (6 ft $10 \mathrm{in})$. The corridor had walls constructed from concrete block with 29 doorways connecting other rooms on either side of the corridor. Except as noted in the experiment descriptions, the doors to the rooms were kept closed. There are 24 sleeping rooms, 12 on the west end and 12 on the east end of the building.

The north side of the day room is open to the adjacent corridor as shown in Figures 2 and 3. The east and west walls of the day room were covered with gypsum board. The south wall of the day room had consisted of a block wall with windows. The wall and the windows were covered with $12 \mathrm{~mm}(0.5 \mathrm{in})$ gypsum board. A drop ceiling, composed of fire resistant-aspen wood fiber tiles, was installed in the day room and corridor areas. Each ceiling tile was approximately $0.61 \mathrm{~m}(2$

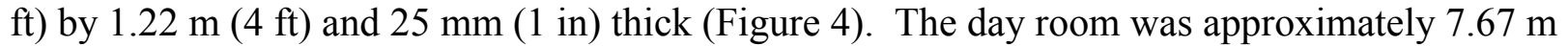
( $25 \mathrm{ft} 2 \mathrm{in})$ by $5.26 \mathrm{~m}$ ( $17 \mathrm{ft} 3 \mathrm{in})$ with a finished ceiling height of $2.23 \mathrm{~m}$ ( $7 \mathrm{ft} 4 \mathrm{in})$.

In all three experiments, there was a vent on the west end of the corridor. The vent was $1.35 \mathrm{~m}$ ( $4 \mathrm{ft} 5 \mathrm{in}$ ) wide, the full width of the corridor, with the opening extending from the floor to 0.61 $\mathrm{m}(2 \mathrm{ft})$ above the floor.

The east end of the corridor was closed with the exception of an open window with dimensions $0.80 \mathrm{~m} \times 0.29 \mathrm{~m}$ or $0.23 \mathrm{~m}^{2}$ of clear area, and a sill height of $1.02 \mathrm{~m}$ above the floor. Also in experiments 1 and 2, 4 windows of the same dimension were open on the northeast portion of the corridor in rooms with the doors closed to the corridor.

In test 3, 5 sleeping room doors were left open on the east end of the corridor. Moving east from the day room, sleeping rooms N4, N3, and N1 on the north side of the corridor and sleeping rooms S5 and S2 on the south side. Each of these rooms had windows open to the outside. The window openings are be defined by the amount of clear open area. On the north side, room three, $0.35 \mathrm{~m}^{2}$, room four, $0.46 \mathrm{~m}^{2}$, room six, $0.92 \mathrm{~m}^{2}$. On the south side, room two, $0.11 \mathrm{~m}^{2}$, and room five, $0.39 \mathrm{~m}^{2}$. Each open doorway is $0.78 \mathrm{~m}$ wide by $2.02 \mathrm{~m}$ high. 


\section{Furnishings}

Each experiment utilized three sofas. Each of the sofas used for the site of ignition were similar in construction. Each was manufactured with an exposed wood frame and fabric covered polyurethane foam cushions (Figure 5). The mass of each sofa was approximately $89 \mathrm{~kg}$ $(195.8 \mathrm{lb})$. The ends of the sofa were composed of solid wood measuring $0.76 \mathrm{~m}$ (30 in) wide, $0.58 \mathrm{~m}$ (23 in) high and $44 \mathrm{~mm}$ (1.75 in) thick. The ends of the sofa were attached together with front and back solid wood supports. Each sofa has three back cushions and three seat cushions. The polyurethane was covered with a thin layer of polyester batting which was covered with a textile material. The back cushions were approximately $0.61 \mathrm{~m}$ (24 in) wide, $0.38 \mathrm{~m}$ (15 in) high and $0.18 \mathrm{~m}$ ( 7 in) thick. The seat cushions were approximately $0.61 \mathrm{~m}$ (24 in) wide, $0.53 \mathrm{~m}(21$ in) deep, and $0.20 \mathrm{~m}(8$ in) thick.

In test 1 , the ignition sofa was of similar construction as the sofas used in tests 2 and 3 however two different types of upholstered sofas were used as "target" fuels in test 1. The "target" sofas were built with a wood frame and had seat cushions filled with polyurethane foam and back cushions filled with polyester batting, see Figure 6 . In tests 2 and 3, all three sofas used in each experiment were similar.

The sofa used for the ignition site was located on the west wall of the day room, $0.91 \mathrm{~m} \mathrm{(3 \textrm {ft } )}$ from the south wall. The second sofa was located on the south wall, $1.83 \mathrm{~m}(6 \mathrm{ft})$ from the west wall. The front face of the third sofa was located $3.2 \mathrm{~m} \mathrm{(10} \mathrm{ft} 6 \mathrm{in})$ north of the south wall and the west side of the sofa was positioned $2.6 \mathrm{~m}$ ( $8 \mathrm{ft} 6 \mathrm{in}$ ) from west wall, see Figure 7.

A bulletin board was located above the sofa on the west wall. The dimensions of the bulletin board were $2.44 \mathrm{~m}(8 \mathrm{ft})$ wide by $1.22 \mathrm{~m}(4 \mathrm{ft})$ high. The bulletin board material was a medium density fiberboard. It was $12 \mathrm{~mm}(0.5 \mathrm{in})$ thick, had a mass of $8.1 \mathrm{~kg}(17.82 \mathrm{lb})$ and was attached directly to the wall. The bulletin board material was framed with wood molding approximately $63.5 \mathrm{~mm}$ ( $2.5 \mathrm{in})$ wide by $12 \mathrm{~mm}(0.5 \mathrm{in})$ thick. The wood molding had a mass of $1.6 \mathrm{~kg}$ $(2.86 \mathrm{lb})$. Two sheets of craft paper were partially pulled down from the bulletin board and draped across the sofa (figure 8). Each piece of paper was approximately $2.33 \mathrm{~m}(7 \mathrm{ft} 7.75 \mathrm{in}$ ) wide by $0.91 \mathrm{~m}(3 \mathrm{ft})$ high. The total mass of the two layers of paper used was $0.3 \mathrm{~kg}(0.66 \mathrm{lb})$. In test 1 the paper was attached directly to the gypsum board wall, no bulletin board was in place.

\section{Instrumentation}

The temperatures were measured with $0.51 \mathrm{~mm}$ ( $0.02 \mathrm{in})$ nominal diameter bare bead, Type $\mathrm{K}$ thermocouples. Ten arrays of thermocouples were installed over the length of the corridor as shown in Figure 9 and two thermocouple arrays were installed in the day room area. The arrays are identified by number in Figures 10 and 11. The locations of the arrays are given in Table 1. Each thermocouple array has a thermocouple located $25 \mathrm{~mm}(1 \mathrm{in}), 0.305 \mathrm{~m}(1 \mathrm{ft}), 0.610 \mathrm{~m}$ $(2 \mathrm{ft}), 0.910 \mathrm{~m}(3 \mathrm{ft}), 1.22 \mathrm{~m}(4 \mathrm{ft}), 1.52 \mathrm{~m}(5 \mathrm{ft})$, and $1.83 \mathrm{~m}(6 \mathrm{ft})$ below the ceiling. Thermocouple arrays in the corridor are along centerline of corridor. The arrays are spaced on 
$7.62 \mathrm{~m}(25 \mathrm{ft})$ intervals, with the exception of the arrays near the east and west ends of the corridor.

Three pairs of Gardon type heat flux gauges are installed near TC arrays 4, 5, 6. The heat flux gauges that were positioned closest to the day room, adjacent to $\mathrm{TC}$ array 6 , had a design heat flux level of $227 \mathrm{~kW} / \mathrm{m}^{2}\left(20 \mathrm{Btu} / \mathrm{ft}^{2} \mathrm{~s}\right)$. The next pair of heat flux gauges positioned to the west, adjacent to TC array 5 , had a design heat flux level of $114 \mathrm{~kW} / \mathrm{m}^{2}\left(10 \mathrm{Btu} / \mathrm{ft}^{2} \mathrm{~s}\right)$. The last pair of heat flux gauges, installed adjacent to TC array 4, had a design heat flux level of $57 \mathrm{~kW} / \mathrm{m}^{2}$ $\left(5 \mathrm{Btu} / \mathrm{ft}^{2} \mathrm{~s}\right)$. Each pair of gauges consists of one gauge facing the ceiling and the other gauge is facing the day room. The height of the gauges facing the ceiling was approximately $0.91 \mathrm{~m}(3 \mathrm{ft})$

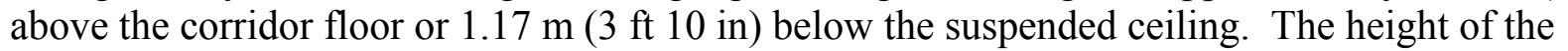
gauges positioned horizontally toward the fire were approximately $0.86 \mathrm{~m} \mathrm{(2 \textrm {ft }} 10 \mathrm{in})$ above the corridor floor or $1.22 \mathrm{~m}(4 \mathrm{ft})$ below the suspended ceiling.

Commercially available ionization smoke alarms were used. The alarms were mounted under the suspended ceiling at the locations shown in Figures 10 and 11. Each alarm was separately connected to the data acquisition system. The voltage change, as measured across the battery terminals at its alarm point, served as the data marker for the alarm time. New smoke alarms were used for each experiment.

\section{Experimental Procedure}

Prior to ignition in each experiment, a computerized data acquisition system was started to collect the temperature, heat flux and smoke detector data. Data were collected from each instrument every $4 \mathrm{~s}$. Video cameras recording the experiment were also started at this time.

After at least $60 \mathrm{~s}$ of background data were collected, a matchbook ignition was used to ignite the bulletin board paper at a location approximately over the center of the intersection of the left and middle sofa seat cushion. In test 1 , the ignition was triggered remotely. At the request of ATF, the ignition was modified for the remaining experiments. In tests 2 and 3, an ATF engineer, in a complete structural fire fighting protective ensemble, ignited the bulletin board paper with a single paper match at approximately the same location.

After ignition, the researcher left the room and exited to the outside of the building via a door in the corridor adjacent to the room. The door was closed and remained closed until the start of suppression activities. The fire growth was observed via monitors connected to the video cameras.

In test 1 fire suppression would begin automatically with the activation of the sprinkler system. Four standard response sprinklers, with activation temperatures of $74^{\circ} \mathrm{C}\left(165^{\circ} \mathrm{F}\right)$ were located under the drop ceiling of the day room, as shown in Figure 3. With one sprinkler flowing the system maintained a pressure of 2.4 bars ( $35 \mathrm{psi}$ ) at the inlet to the building and a flow rate of $1.7 \mathrm{~L} / \mathrm{s}(27 \mathrm{gpm})$. The water supply maintained a static pressure of approximately 3.4 bars 
(50 psig). In tests 2 and 3, manual fire suppression activities were planned to start at approximately 15 minutes after ignition.

Tests 2 and 3 are identical with the exception of the corridor ventilation. The differences in vent arrangement occur on the portion of the corridor to the east of the fire room as described in the test arrangement section.

All of the fire experiments were conducted in the same space. After each experiment, the day room and the adjoining corridor were dried out. Broken or wet ceiling tiles were replaced and the wall surfaces were patched or repaired as needed. Furnishings, thermocouple arrays in the dayroom and smoke detectors were also replaced before each experiment.

Each experiment was documented using thermally protected video cameras. As shown in Figure 11 , two video cameras were capturing an east to west and a north to south view of the day room. Both cameras were installed close to the floor. A third camera was installed, on the floor, in the vent at the west end of the corridor looking east.

\section{Results}

The results of the experiments include experiment timelines, smoke alarm and sprinkler activation times, temperature measurements, heat flux measurements, photographs and videos.

\section{Experiment Timelines}

The timelines are developed from observations made during the experiment, review of the video of the experiment, and review of the data. The timelines for experiments 1,2, and 3 are given in Tables 2, 3, and 4 respectively. Post test photographs of the day room are presented in Figures 12 through 14.

\section{$\underline{\text { Smoke Alarm and Sprinkler Activation Times }}$}

The smoke alarm activation and sprinkler activation times are given in Table 5 for experiment 1 . The smoke alarm activation times are given in Table 6 for experiment 2 and Table 7 for experiment 3 .

\section{$\underline{\text { Temperature Data }}$}

The temperature measurements are given in Figure 17 through 28 for experiment 1, Figures 29 through 40 for experiment 2 and in Figures 41 through 52 for experiment 3 . The temperature measurements have been plotted on scales that optimize the separation of the data points for clarity. Certain data will be re-plotted on similar scales for comparison purposes later in the paper. Reviewing the times at which the temperatures begin to increase provides some sense of how rapidly the smoke is spreading down the corridor. 
In experiment 1 , the sprinklered case, temperatures near the ceiling in the day room, thermocouple array 7 , approach $245^{\circ} \mathrm{C}\left(473^{\circ} \mathrm{F}\right)$ just prior to sprinkler activation at $137 \mathrm{~s}$, Figure 23 . In the corridor adjacent to the day room, thermocouple array 6 , the temperature near the ceiling exceeds $120^{\circ} \mathrm{C}\left(248^{\circ} \mathrm{F}\right)$ for approximately $10 \mathrm{~s}$ prior to sprinkler activation. At approximately $1.5 \mathrm{~m}(5 \mathrm{ft})$ above the floor in the corridor, the maximum temperature is approximately $50{ }^{\circ} \mathrm{C}\left(122^{\circ} \mathrm{F}\right)$, Figure 22 . The temperatures then decrease rapidly at the corridor positions to the east and west of the day room. At the west end of the corridor, the maximum temperature increase just below the ceiling is $20^{\circ} \mathrm{C}\left(68^{\circ} \mathrm{F}\right)$, Figure 28 . At the east end of the corridor, the temperature increase is approximately $10{ }^{\circ} \mathrm{C}\left(50^{\circ} \mathrm{F}\right)$, Figure 17 . The thermocouple located $1.83 \mathrm{~m}$ below the ceiling in TC array 8, was not functioning and therefore is not shown in Figure 24.

The temperature measurements for experiment 2 , the first un-sprinklered case are overall significantly higher than the temperatures recorded during experiment 1 . The peak temperatures near the ceiling range from $780{ }^{\circ} \mathrm{C}\left(1436{ }^{\circ} \mathrm{F}\right)$ at thermocouple array 7 , Figure 35 , to $120^{\circ} \mathrm{C}$ $\left(248^{\circ} \mathrm{F}\right)$, at thermocouple array 1 near the east end of the corridor, Figure 29. The maximum temperature at the west end of the corridor is $170^{\circ} \mathrm{C}\left(338^{\circ} \mathrm{F}\right)$, Figure 40 . Figure 40 also shows that the peak temperature at approximately $1.5 \mathrm{~m}(5 \mathrm{ft})$ above the floor is $140^{\circ} \mathrm{C}\left(284^{\circ} \mathrm{F}\right)$.

In experiment 3, the second un-sprinklered experiment, the ventilation to the test area was increased. This resulted in increased temperatures relative to experiment 2 . The peak temperatures near the ceiling range from $900^{\circ} \mathrm{C}\left(1652^{\circ} \mathrm{F}\right)$ at thermocouple array 7 , Figure 47 , to $240^{\circ} \mathrm{C}\left(464^{\circ} \mathrm{F}\right)$, at thermocouple array 1 near the east end of the corridor, Figure 41 . The maximum temperature at the west end of the corridor is $230{ }^{\circ} \mathrm{C}\left(446^{\circ} \mathrm{F}\right)$, Figure 52 . Figures 41 and 52 also show that the peak temperatures at approximately $1.5 \mathrm{~m}(5 \mathrm{ft})$ above the floor exceed $170{ }^{\circ} \mathrm{C}\left(338^{\circ} \mathrm{F}\right)$ at both ends of the corridor remote from the day room. After $400 \mathrm{~s}$, the temperatures at TC array 7 decrease in a manner that is inconsistent with TC array 6 and TC array 8. During this time, portions of the suspended ceiling in the day room are collapsing which displaced the TC array. This coupled with potential burn through on the TC insulation may have lead to the inconsistent behavior. It should be noted that the data for experiment 3 ends abruptly because the data acquisition system had to be removed from the building due to heavy smoke conditions.

\section{$\underline{\text { Heat Flux Data }}$}

In experiment 1 , the heat flux gauge facing the ceiling had a peak reading of $0.9 \mathrm{~kW} / \mathrm{m}^{2}$, prior to sprinkler activation. All of the other heat flux readings were less than $0.2 \mathrm{~kW} / \mathrm{m}^{2}$, indistinguishable from background values.

The heat flux data from experiment 2 is presented in Figures 52 through 55. The data associated with the "V" legend is measured with the gauge aimed at the ceiling. The data associated with the " $\mathrm{H}$ " legend is measured with the gauge aimed horizontally in the direction of the fire. The maximum heat flux adjacent to TC array 6 is approximately $10 \mathrm{~kW} / \mathrm{m}^{2}$ and occurs at approximately $375 \mathrm{~s}$. There are a few readings of higher magnitude later in the fire, this may be attributed to brief flame contact in the area of the heat flux sensor facing the day room. At the 
heat flux location adjacent to TC array 4, approximately $15.24 \mathrm{~m}(50 \mathrm{ft})$ west of TC array 6 , the maximum heat flux was approximately $1.5 \mathrm{~kW} / \mathrm{m}^{2}$.

The heat flux data from experiment 3 is given in Figures 56 through 58. The peak heat flux, adjacent to the day room, is in excess of $60 \mathrm{~kW} / \mathrm{m}^{2}$. The peak heat flux at $7.62 \mathrm{~m}(25 \mathrm{ft})$ and $15.24 \mathrm{~m}(50 \mathrm{ft})$ to the west is approximately $20 \mathrm{~kW} / \mathrm{m}^{2}$ and $3 \mathrm{~kW} / \mathrm{m}^{2}$, respectively.

\section{$\underline{\text { Uncertainty Analysis }}$}

There are different components of uncertainty in the temperatures and total heat flux reported here. Uncertainties are grouped into two categories according to the method used to estimate them. Type A uncertainties are evaluated by statistical methods, and Type B are evaluated by other means [4]. Type B analysis of systematic uncertainties involves estimating the upper $(+a)$ and lower $(-a)$ limits for the quantity in question such that the probability that the value would be in the interval $( \pm \mathrm{a})$ is essentially 100 percent. After estimating uncertainties by either Type A or B analysis, the uncertainties are combined in quadrature to yield the combined standard uncertainty. Multiplying the combined standard uncertainty by a coverage factor of two, results in the total expanded uncertainty that corresponds to an approximate 95 percent confidence interval $(2 \sigma)$.

Components of uncertainty are tabulated in Table 8. Some of these components, such as the zero and calibration elements, are derived from instrument specifications. Other components, such as soot deposition or radiative cooling/heating include past experience with thermophoretic deposition on cool surfaces and thermocouples in high temperature fuel rich environments. The uncertainty in the gas temperature measurements includes radiative cooling in the each of the tests series, but also includes radiative heating for thermocouple located in the lower layer of the full-scale tests. Small diameter thermocouples were used to limit the impact of radiative heating and cooling. This resulted in an estimate of $\pm 15 \%$ total expanded uncertainty.

The potential for soot deposition on the face of the water-cooled total heat flux gauges contributed significant uncertainty to the heat flux measurements. Calibration of heat flux gauges was completed at lower fluxes and then extrapolated to higher values and this resulted in a higher uncertainty in the flux measurement. Combining all of component uncertainties for total heat flux resulted in a total expanded uncertainty of $-24 \%$ to $+13 \%$ for the flux measurements.

\section{Discussion}

The life safety hazards generated by a fire include; heat, toxic gases, and loss of visibility. In these experiments only quantitative measures of heat were made and some qualitative measures of visibility were made with the video cameras. 
Heat can be transferred by conduction, convection and radiation. Burn injuries caused by the combustion products (smoke), can be caused by convection and/or radiant heat transfer. Here we are not considering contact burn injuries due to touching hot surfaces.

As presented in the SFPE Handbook of Fire Protection Engineering, estimated limits for tenability due to convected heat suggest a thermal tolerance of $120^{\circ} \mathrm{C}\left(248^{\circ} \mathrm{F}\right)$. Above this limit, the onset of pain is rapid and burns can develop within a few minutes or less. The estimated tenability limit due to heat flux is $2.5 \mathrm{~kW} / \mathrm{m}^{2}$. At this level, the time to burn unprotected skin is $20 \mathrm{~s}$ or less [5].

These limits are not absolute limits since clothing, humidity, skin composition etc, can mitigate or exacerbate the impact of the thermal energy for a given heat level and exposure time. These values will be used as bench marks for the discussion presented here. It is also important to note that as the fire grows, the temperatures in some areas of the day room and corridor increase rapidly and quickly bypass the benchmark thresholds making concerns over uncertainty in the tenability limits a minor point.

Since this discussion is focused on tenability, the temperatures at approximately $1.5 \mathrm{~m}(5 \mathrm{ft})$ above the floor are of the most interest. Therefore, the temperature data will be reduced to the measurement locations at $0.61 \mathrm{~m}(2 \mathrm{ft})$ below the ceiling. This yielded a height above the floor of $1.62 \mathrm{~m}(5.3 \mathrm{ft})$ in the day room and a height above the floor of $1.47 \mathrm{~m},(4.8 \mathrm{ft})$ in the corridor.

Two temperature graphs for each experiment have been prepared (see Figures 59 through 64). Each graph presents the temperatures starting at TC array 6 , the corridor array nearest the day room, and incorporates the rest of the corridor TC arrays moving either to the east or the west. These graphs show how the temperature time histories, at $0.61 \mathrm{~m}(2 \mathrm{ft})$ below the ceiling, change as the distance between the fire and the measurement array increases.

Figures 59 and 60 show the temperatures for experiment 1 in the west and east sides of the corridor respectively. At no time during experiment 1, at any of the TC array positions in the corridor, does the temperature exceed $120^{\circ} \mathrm{C}\left(248^{\circ} \mathrm{F}\right)$ at $0.61 \mathrm{~m}$ below the ceiling or lower.

For the un-sprinklered experiments, 2 (Figures 61 and 62) and 3 (Figures 63 and 64), most of the temperature histories exceed $120^{\circ} \mathrm{C}\left(248^{\circ} \mathrm{F}\right)$. The exception is in experiment 2 , the TC arrays 1 and 2, which are $30.5 \mathrm{~m}(100 \mathrm{ft})$ or more west of TC array 6 , were over $100^{\circ} \mathrm{C}\left(212^{\circ} \mathrm{F}\right)$, but did not exceed $120^{\circ} \mathrm{C}\left(248^{\circ} \mathrm{F}\right)$.

In experiment 2 the tenability benchmark is exceeded at approximately 3 minutes after ignition at $\mathrm{TC}$ array 6 . It takes approximately 2 minutes more for the fire to grow to the extent needed to generate temperatures in excess of $120^{\circ} \mathrm{C}\left(248^{\circ} \mathrm{F}\right)$ at the end of the east corridor.

In Figures 63 and 64, note that the peak temperatures at TC array 6 were clipped off in order to have a $y$ axis with a smaller temperature range so that some separation could be seen at the TC arrays to the east and to the west. In experiment 3 , the temperature at $\mathrm{TC}$ array 6 exceeds $120^{\circ} \mathrm{C}$ $\left(248{ }^{\circ} \mathrm{F}\right)$ at approximately $3 \frac{1}{2}$ minutes. Again it takes approximately 2 additional minutes for 
similar temperature conditions to exist $26.9 \mathrm{~m}(88 \mathrm{ft})$ down the east corridor. At approximately 6 minutes after ignition, temperatures above $120^{\circ} \mathrm{C}\left(248^{\circ} \mathrm{F}\right)$ are measured $32.4 \mathrm{~m}(106 \mathrm{ft})$ down the corridor to the west.

The temperature comparisons at $\mathrm{TC}$ array 7, the closest array to the ignition sofa, are given in Figure 65. It shows the temperature for experiment 2 increase the fastest, rising above $120^{\circ} \mathrm{C}$ $\left(248^{\circ} \mathrm{F}\right)$ in less than 3 minutes after ignition. The fire in experiment 3 developed a little slower, requiring another $30 \mathrm{~s}$ to reach the same temperature. Again the temperatures in the sprinklered experiment, Day Room 1, remain in the tenable range for the duration of the experiment.

Referring back to Figures 52 through 58, it can be seen that the reduction in measured heat flux is significant at positions remote from the day room. For example, in experiment 3 , the peak heat flux from the hot gas layer exceeds $65 \mathrm{~kW} / \mathrm{m}^{2}$ at the position adjacent to TC array 6 , then decreases to approximately $20 \mathrm{~kW} / \mathrm{m}^{2}, 7.62 \mathrm{~m}(25 \mathrm{ft})$ to the west, near TC array 5 . Looking at the data from a position adjacent to TC array 4 , which is another $7.62 \mathrm{~m}(25 \mathrm{ft})$ to the west, the peak heat flux has been reduced to approximately $3 \mathrm{~kW} / \mathrm{m}^{2}$.

\section{Conclusions}

Three full-scale fire experiments were conducted in an abandoned dormitory to examine the impact of sprinklers on reducing the thermal hazards generated by a day room fire. The fire scenario was designed to represent a realistic fire hazard, based on school dormitory fire incident statistics. The recommended thermal tenability levels from the SFPE Handbook of Fire Protection Engineering, $120^{\circ} \mathrm{C}\left(248^{\circ} \mathrm{F}\right)$ for temperature and $2.5 \mathrm{~kW} / \mathrm{m}^{2}$ for heat flux were used to compare the data against.

In the un-sprinklered experiments, the temperature tenability limits were exceeded in the corridor at locations remote from the fire, $22.9 \mathrm{~m}$ (75ft) or more. Untenable conditions due to heat flux were also generated in the corridor in the un-sprinklered fire experiments. The untenable conditions began in the corridor as early as 3 minutes after ignition and spread through the corridor within another 3 minutes.

In the sprinklered experiment at no time did the temperatures in the day room or in the corridor exceed $120^{\circ} \mathrm{C}\left(248{ }^{\circ} \mathrm{F}\right)$ at the $1.5 \mathrm{~m}(5 \mathrm{ft})$ level above the floor or below. No significant increases in heat flux above ambient conditions were measured in the corridor. The experiments demonstrate the significant improvement to life safety that an automatic sprinkler system can provide.

\section{Acknowledgements}

The authors would like to thank the Myrtle Beach Air Force Base Redevelopment Authority and the Myrtle Beach Fire Department for supporting the conduct of the experiments and providing logistical and fire fighting support. The authors would also like to acknowledge Gerald Haynes 
of the Bureau of Alcohol, Tobacco and Firearms, for his guidance in the design of the experiments and his assistance in the conduct of the experiments. The authors would like to recognize, Dr. Glenn Forney, Mr. Laurean DeLauter, Mr. Jack Lee, Mr. Jay McElroy, Mr. Gary Roadarmel, Mr. William Twilley, and Mr. Robert Vettori of the Building and Fire Research Laboratory at NIST, for the invaluable support that they provided during this series of experiments. Finally, the authors express gratitude to the United States Fire Administration and Mr. Larry Maruskin for their sponsorship and support of this important research program.

\section{References}

[1] Dormitory Fires, U.S. Fire Administration Topical Fire Research Series, Vol.1, Issue 14. Federal Emergency Management Agency, United States Fire Administration, National Fire Data Center, Emmitsburg, MD, March 2001.

[2] Rohr, Kimberly, D., School, College, and University Dormitories, and Fraternity and Sorority House Fires in the United States, 1994-1998 Annual Averages. National Fire Protection Association, Quincy, MA, June 2001.

[3] Rohr, Kimberly, D., U.S. Experience with Sprinklers. National Fire Protection Association, Quincy, MA, September 2003.

[4] Taylor, B.N. and Kuyatt, C.E., "Guidelines for Evaluating and Expressing the Uncertainty of NIST Measurement Results," NIST TN 1297, National Institute of Standards and Technology, Gaithersburg, MD, January 1994.

[5] Purser, D.A., Toxicity Assessment of Combustion Products. SFPE Handbook of Fire Protection Engineering, $3^{\text {rd }}$ ed.. DiNenno, P.J., et. al. (eds). NFPA Quincy, MA, 2002. 
Table 1. Thermocouple Array (TC) and Smoke Alarm (SA) Locations

\begin{tabular}{|c|c|}
\hline Thermocouple Array (TC) & Location from west end of corridor \\
\hline 1 & $0.15 \mathrm{~m}(6 \mathrm{in})$ from west end of corridor \\
\hline 2 & $2.11 \mathrm{~m}(6 \mathrm{ft} 11 \mathrm{in})$ from west end of corridor \\
\hline 3 & 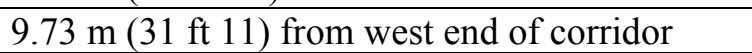 \\
\hline 4 & $17.35 \mathrm{~m}(56 \mathrm{ft} 11 \mathrm{in})$ from west end of corridor \\
\hline 5 (SA $4,0.93 \mathrm{~m}(1 \mathrm{ft} 9 \mathrm{in})$ to the west) & $24.96 \mathrm{~m}(81 \mathrm{ft} 11 \mathrm{in})$ from west end of corridor \\
\hline 6 (SA 1) & $32.59 \mathrm{~m}(106 \mathrm{ft} 11 \mathrm{in})$ from west end of corridor \\
\hline 7 (SA 3) & $\begin{array}{l}2.89 \mathrm{~m}(9 \mathrm{ft} 6 \mathrm{in}) \text { from west day room wall, } \\
1.83 \mathrm{~m}(6 \mathrm{ft}) \text { from south wall }\end{array}$ \\
\hline 8 (SA 2) & $\begin{array}{l}5.38 \mathrm{~m}(17 \mathrm{ft} 8 \mathrm{in}) \text { from west day room wall, } \\
1.83 \mathrm{~m}(6 \mathrm{ft}) \text { from south wall }\end{array}$ \\
\hline 9 (SA 5, $8 \mathrm{ft}$ to the east) & $40.21 \mathrm{~m}(131 \mathrm{ft} 11 \mathrm{in})$ from west end of corridor \\
\hline 10 & $47.83 \mathrm{~m}(156 \mathrm{ft} 11 \mathrm{in})$ from west end of corridor \\
\hline 11 & $55.45 \mathrm{~m}(181 \mathrm{ft} 11 \mathrm{in})$ from west end of corridor \\
\hline 12 & $59.49 \mathrm{~m}(195 \mathrm{ft} 2 \mathrm{in})$ from west end of corridor \\
\hline
\end{tabular}


Table 2. Timeline for Experiment Number 1

$\underline{\text { Time }} \quad \underline{\text { Observation }}$

$0 \mathrm{~s} \quad$ Ignition

$15 \mathrm{~s} \quad$ Flames spreading up the paper to the point attached to the wall

$20 \mathrm{~s} \quad$ Day room, west side, smoke alarm (SA3) activated

$25 \mathrm{~s} \quad$ Flames involving most of the paper, flames near ceiling

$25 \mathrm{~s} \quad$ East Corridor, SA5 activated

$35 \mathrm{~s} \quad$ Paper burning and falling, fire decreasing

$45 \mathrm{~s} \quad$ West Corridor, SA4 activated

$60 \mathrm{~s} \quad$ Fire on sofa cushion, small flames on paper still attached to wall, paper burning on floor

$60 \mathrm{~s} \quad$ Day room corridor SA1 activated

$90 \mathrm{~s} \quad$ Smoke plume from center of sofa has gotten darker, more visible, fire increasing in size, most of center cushion involved in fire

$105 \mathrm{~s} \quad$ Visible smoke layer across day room ceiling

$120 \mathrm{~s} \quad$ Flames to ceiling, smoke layer getting thicker

$137 \mathrm{~s} \quad$ SW sprinkler activated

$150 \mathrm{~s} \quad$ Small flames visible on sofa

$165 \mathrm{~s} \quad$ Flames no longer visible, appear to be out

$180 \mathrm{~s} \quad$ Smoke visible, one end of north sofa visible

$210 \mathrm{~s} \quad$ Visibility continues to decrease

$265 \mathrm{~s} \quad$ Sprinkler turned off

$350 \mathrm{~s} \quad$ Fire fighters enter building

$360 \mathrm{~s} \quad$ Visibility improving

$380 \mathrm{~s} \quad$ Turned off light in fire area

Post-Test Fire damage limited to ignition sofa and the wall behind the sofa. Soot marks on ceiling tile. Other sofas were not involved in fire. 
Table 3. Timeline for Experiment Number 2

\section{$\underline{\text { Time }} \quad \underline{\text { Observation }}$}

$0 \mathrm{~s} \quad$ Ignition

$12 \mathrm{~s} \quad$ West day room SA3 activated

$28 \mathrm{~s} \quad$ East day room SA2 activated

$30 \mathrm{~s} \quad$ Paper fully involved

$32 \mathrm{~s} \quad$ Day room corridor SA1 activated

$44 \mathrm{~s} \quad$ East corridor SA5 activated

$56 \mathrm{~s} \quad$ West corridor SA4 activated

$60 \mathrm{~s} \quad$ Fire decreasing in size, small flames on bulletin board, small fire on sofa

$120 \mathrm{~s} \quad$ Flames from sofa and bulletin board to ceiling

$150 \mathrm{~s} \quad$ Flames reaching across west wall near ceiling

$185 \mathrm{~s} \quad$ Sofa on south wall starts pyrolizing

$200 \mathrm{~s} \quad$ Ignition sofa fully involved

$220 \mathrm{~s} \quad$ Sofa centered in room begins to pyrolize

$245 \mathrm{~s}$

$285 \mathrm{~s}$

$930 \mathrm{~s}$

Smoke is filling the day room, fire "darkening down"

Visibility from cameras is lost

Fire fighters enter building

Post Test Most of the foam on the ignition sofa is burned away. A small amount of burning occurred on the target sofas, most of the foam cushions remain. Fire damage on upper portions of walls adjacent to ignition sofa. Ceiling damage limited to area close to ignition sofa. 
Table 4. Timeline for Experiment Number 3

\section{$\underline{\text { Time }} \quad \underline{\text { Observation }}$}

$0 \mathrm{~s} \quad$ Ignition

$40 \mathrm{~s} \quad$ East day room SA2 activated

$40 \mathrm{~s} \quad$ West day room SA3 activated

$44 \mathrm{~s} \quad$ Dayroom Corridor SA1 activated

$45 \mathrm{~s} \quad$ Paper fully involved, flames to ceiling

$56 \mathrm{~s} \quad$ East corridor SA5 activated

$60 \mathrm{~s} \quad$ Fire decreased in size, small flames on bulletin board, small fire on sofa

$165 \mathrm{~s} \quad$ Flames from sofa and bulletin board extend to ceiling

$180 \mathrm{~s} \quad$ Flames spread across west wall near ceiling

$225 \mathrm{~s} \quad$ Ignition sofa fully involved

$235 \mathrm{~s} \quad$ Sofa on south wall started pyrolizing

$275 \mathrm{~s} \quad$ Sofa centered in room began to pyrolize

$325 \mathrm{~s} \quad$ Sofa on south wall ignited

$350 \mathrm{~s} \quad$ Sofa centered in room ignited

$920 \mathrm{~s} \quad$ Firefighters entered building

$960 \mathrm{~s} \quad$ Fire is extinguished

Post Test All of the ceiling tile is burned or down on the floor with the exception of a row of tiles on the east end of the day room. All of the foam cushions have burned away completely. Significant burn damage to walls. Burn line in day room on east and south walls stops approximately $0.5 \mathrm{~m}$ above the floor. Fire damage (evidence of burning) in corridor limited to area across from day room with some extension to the east and west. 
Table 5. Day Room Experiment 1, Smoke Alarm Activation and Sprinkler Activation Times

\begin{tabular}{|l|l|l|}
\hline Smoke Alarm & Location & Time (s) \\
\hline 1 & Dayroom Corridor & 60 \\
\hline 2 & Dayroom, east side & $*$ \\
\hline 3 & Dayroom, west side (ign) & 20 \\
\hline 4 & West Corridor & 45 \\
\hline 5 & East Corridor & 25 \\
\hline Sprinkler Activation & & \\
\hline 1 & Dayroom SW & 137 \\
\hline 2 & Dayroom NW & Did not activate \\
\hline 3 & Dayroom NE & Did not activate \\
\hline 4 & Dayroom SE & Did not activate \\
\hline
\end{tabular}

* The device activation time was not recorded due to an instrumentation malfunction.

Table 6. Day Room Experiment 2, Smoke Alarm Activation Times

\begin{tabular}{|l|l|l|}
\hline Smoke Alarm & Location & Time (s) \\
\hline 1 & Dayroom Corridor & 32 \\
\hline 2 & Dayroom, east side & 28 \\
\hline 3 & Dayroom, west side (ign) & 12 \\
\hline 4 & West Corridor & 56 \\
\hline 5 & East Corridor & 44 \\
\hline
\end{tabular}

Table 7. Day Room Experiment 3, Smoke Alarm Activation Times

\begin{tabular}{|l|l|l|}
\hline Smoke Alarm & Location & Time (s) \\
\hline 1 & Dayroom Corridor & 44 \\
\hline 2 & Dayroom, east side & 40 \\
\hline 3 & Dayroom, west side (ign) & 40 \\
\hline 4 & West Corridor & $*$ \\
\hline 5 & East Corridor & 56 \\
\hline
\end{tabular}

* Device activation time was not recorded due to an instrumentation malfunction. 
Table 8. Estimated Uncertainty in Full Scale Experimental Data.

\begin{tabular}{|c|c|c|c|}
\hline & $\begin{array}{l}\text { Component } \\
\text { Standard } \\
\text { Uncertainty }\end{array}$ & $\begin{array}{l}\text { Combined } \\
\text { Standard } \\
\text { Uncertainty }\end{array}$ & $\begin{array}{c}\text { Total } \\
\text { Expanded } \\
\text { Uncertainty }\end{array}$ \\
\hline $\begin{array}{l}\text { Gas Temperature } \\
\text { Calibration } \\
\text { Radiative Cooling } \\
\text { Radiative Heating } \\
\text { Repeatability }^{1} \\
\text { Random }^{1}\end{array}$ & $\begin{array}{c} \pm 1 \% \\
-5 \% \text { to }+0 \% \\
-0 \% \text { to }+5 \% \\
\pm 5 \% \\
\pm 3 \%\end{array}$ & $-8 \%$ to $+8 \%$ & $-15 \%$ to $+15 \%$ \\
\hline $\begin{array}{l}\text { Total Heat Flux } \\
\text { Calibration } \\
\text { Zero } \\
\text { Soot Deposition } \\
\text { Repeatability }^{1} \\
\text { Random }^{1}\end{array}$ & $\begin{array}{c} \pm 3 \% \\
-2 \% \text { to }+2 \% \\
-10 \% \text { to }+0 \% \\
\pm 5 \% \\
\pm 3 \%\end{array}$ & $-12 \%$ to $+7 \%$ & $-24 \%$ to $+13 \%$ \\
\hline
\end{tabular}

Notes: 1. Random and repeatability evaluated as Type A, other components as Type B. 


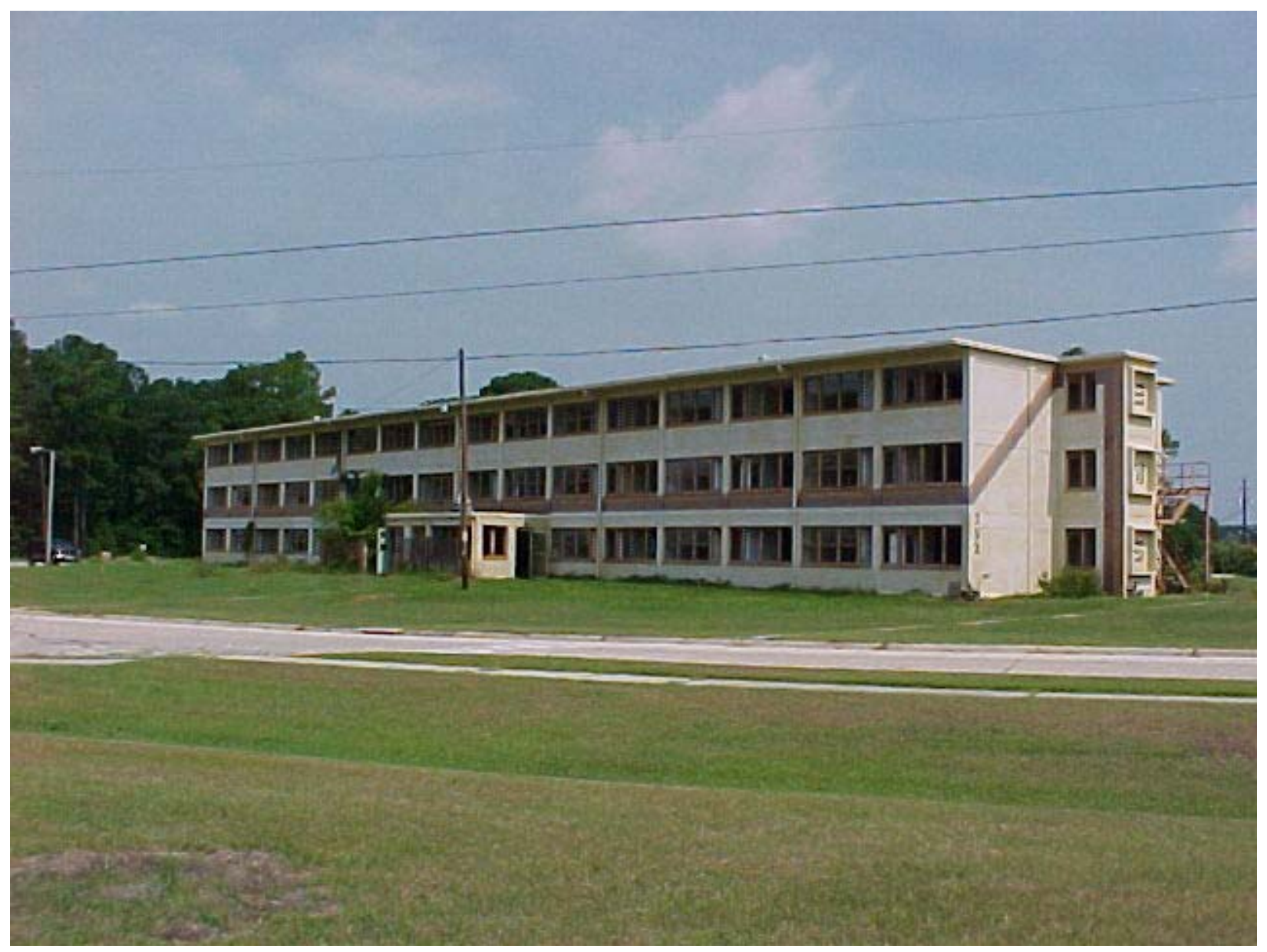

Figure 1. Photograph of dormitory building, similar to the test structure. 


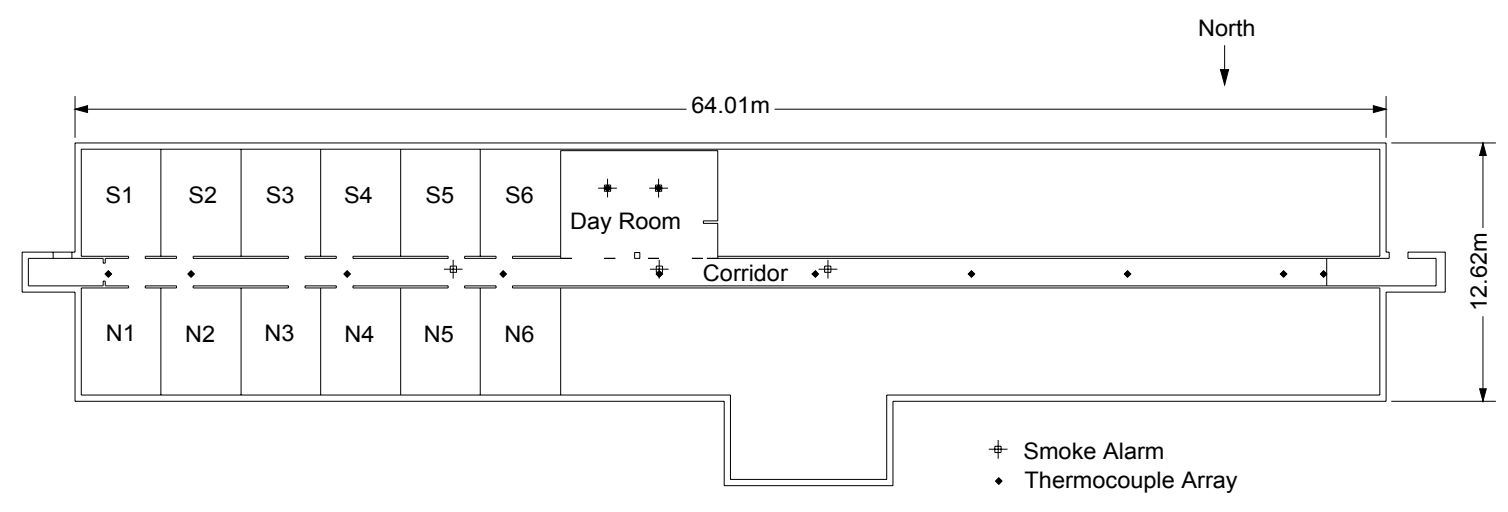

Figure 2. Arrangement of the dormitory building, $1^{\text {st }}$ floor. 


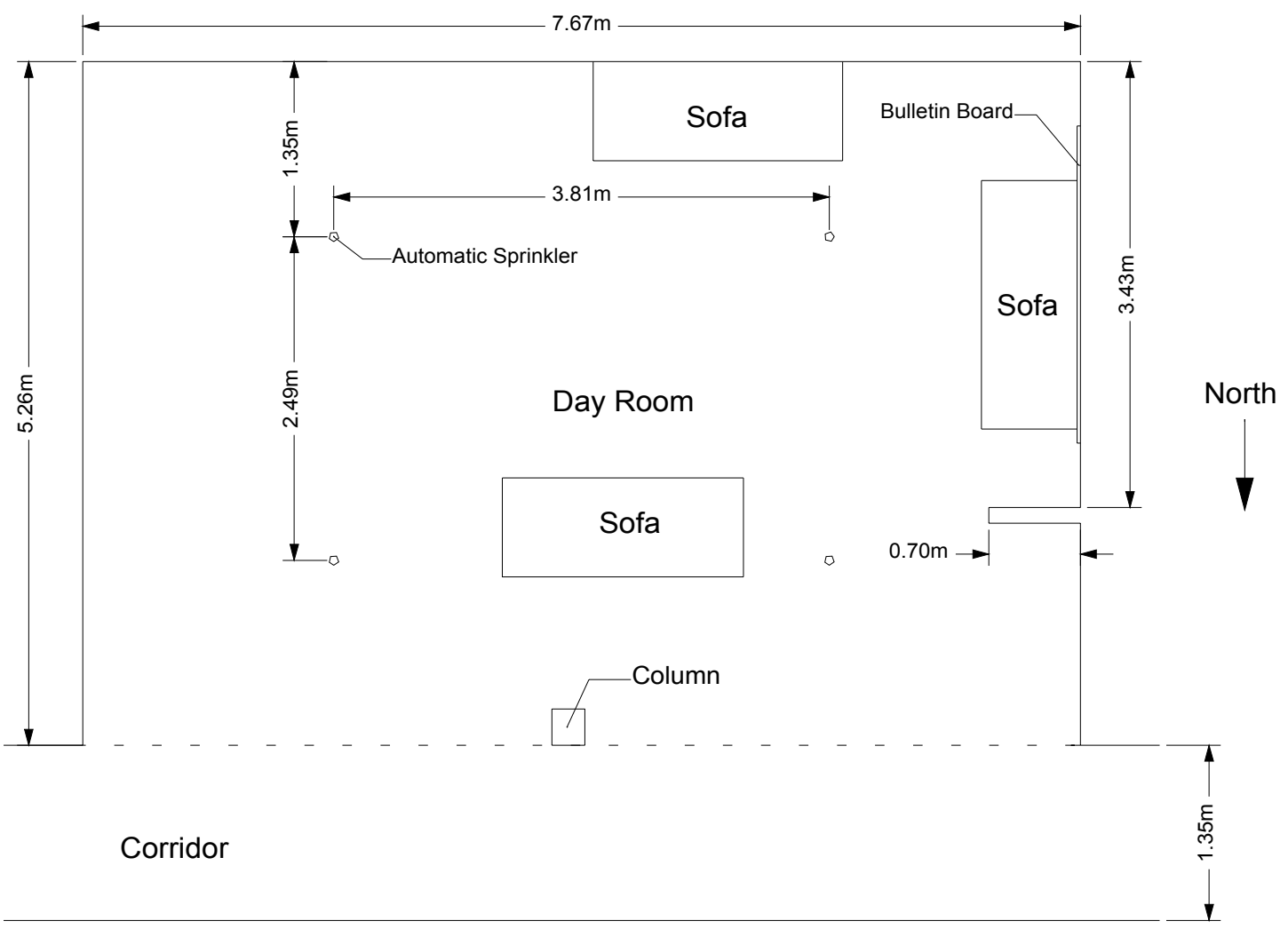

Figure 3. Plan view of Day Room with sprinkler locations. 


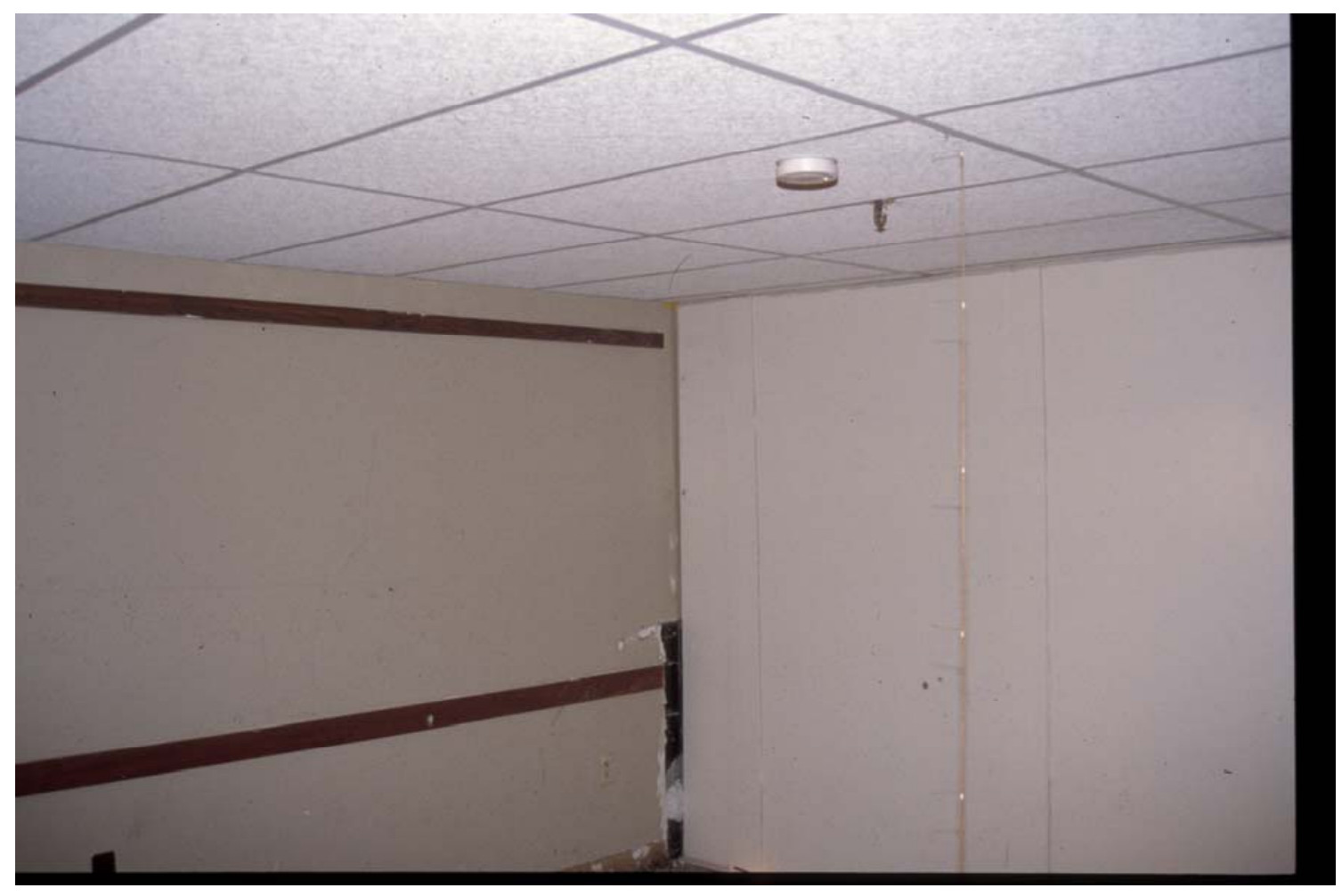

Figure 4. Photograph showing ceiling tile 


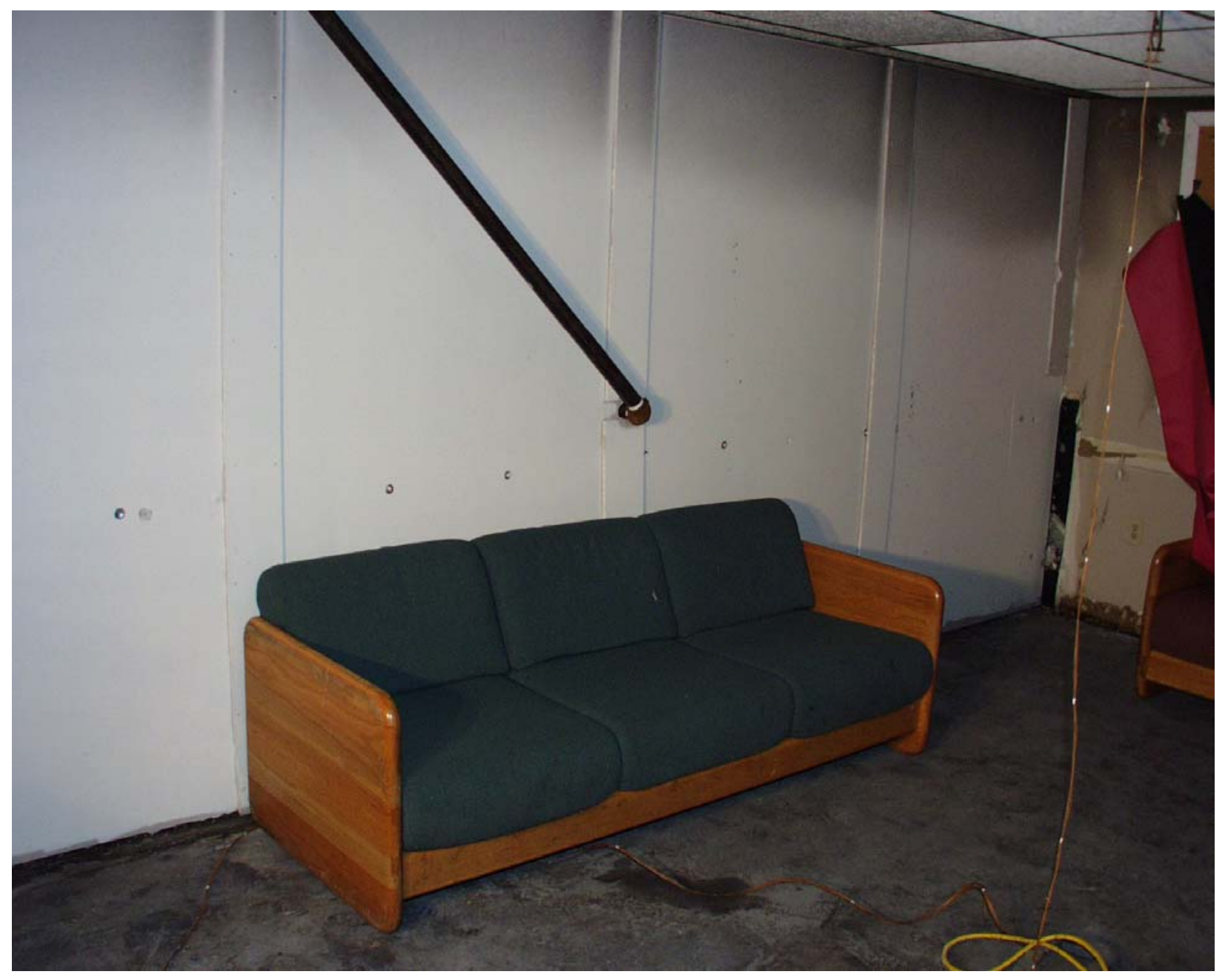

Figure 5. Photograph of the type of sofa used for ignition in all of the experiments and used as "target" sofas in experiments 2 and 3. 


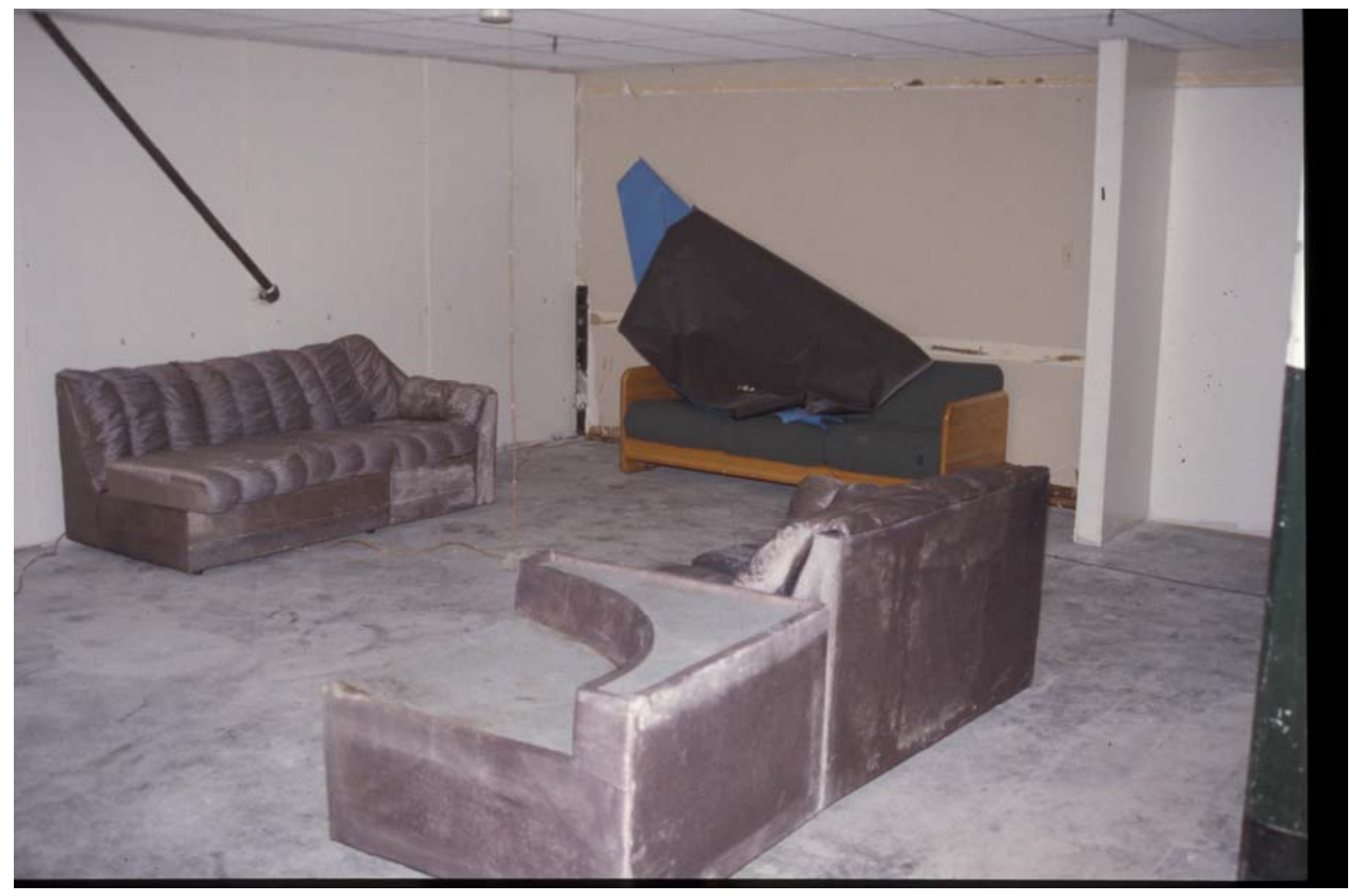

Figure 6. Photograph showing the fuel arrangement for the day room in experiment 1. 


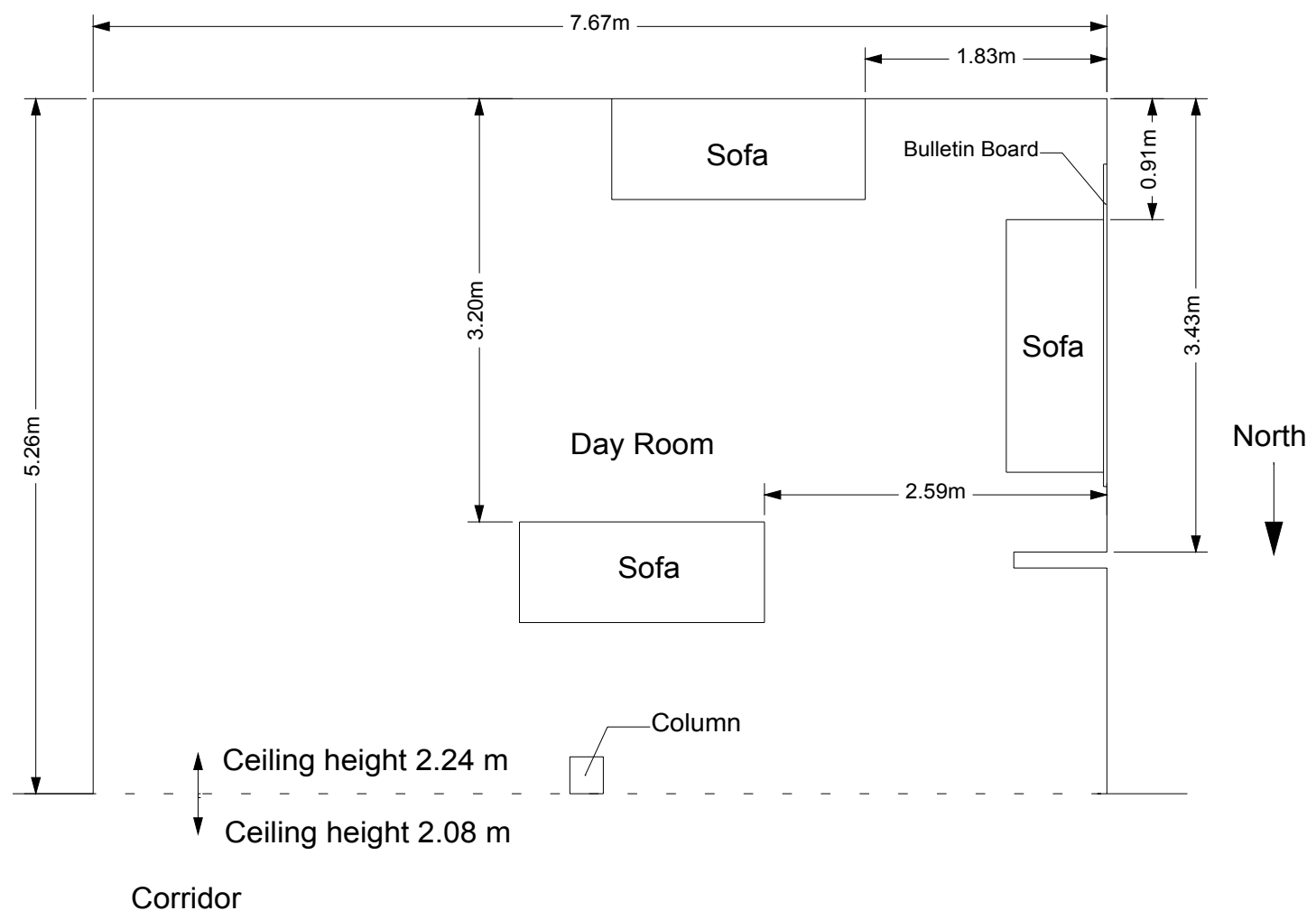

Figure 7. Diagram of day room showing sofa arrangement. 


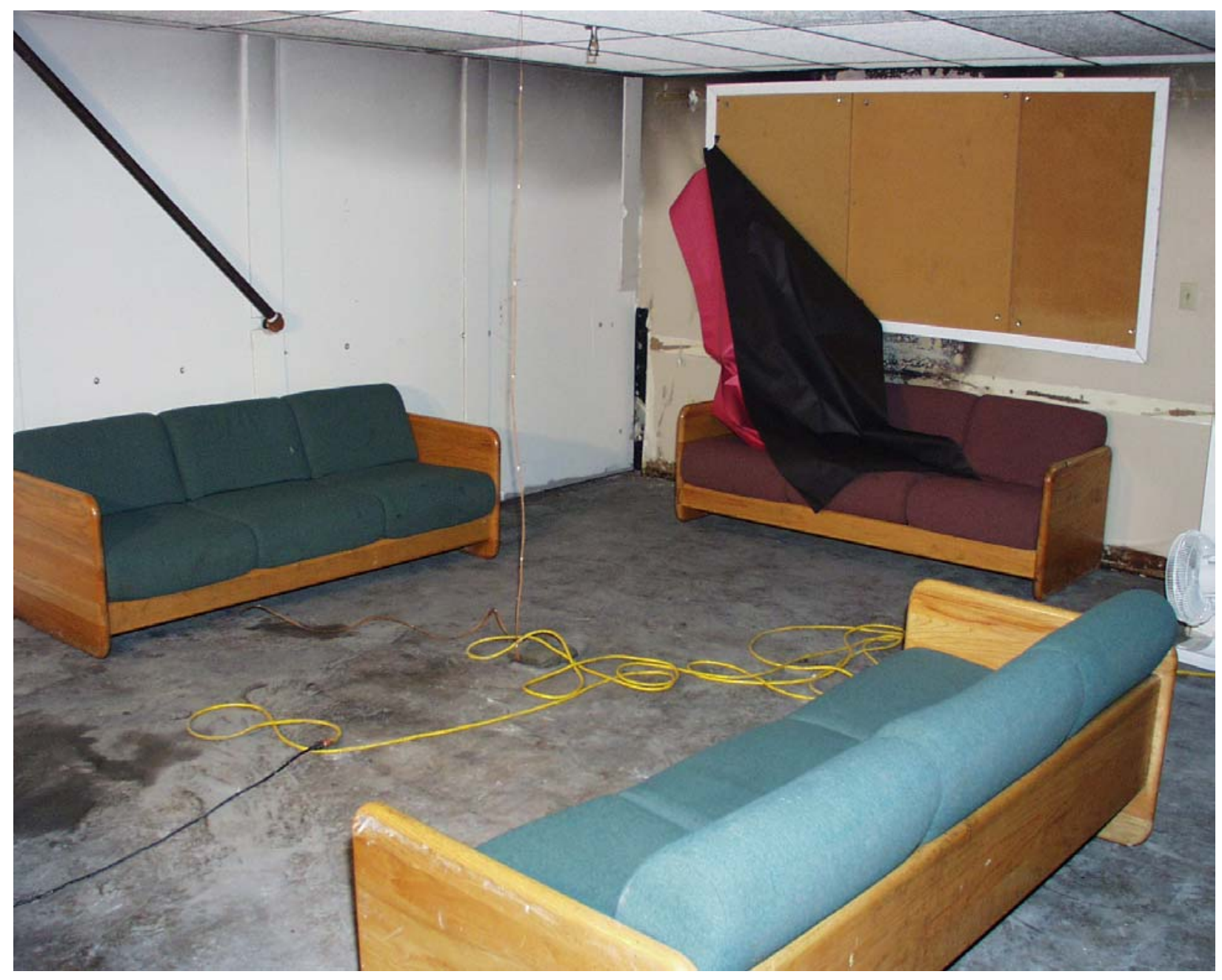

Figure 8. Photograph showing dayroom arrangement for experiment 2, with sofas, bulletin board and paper. 


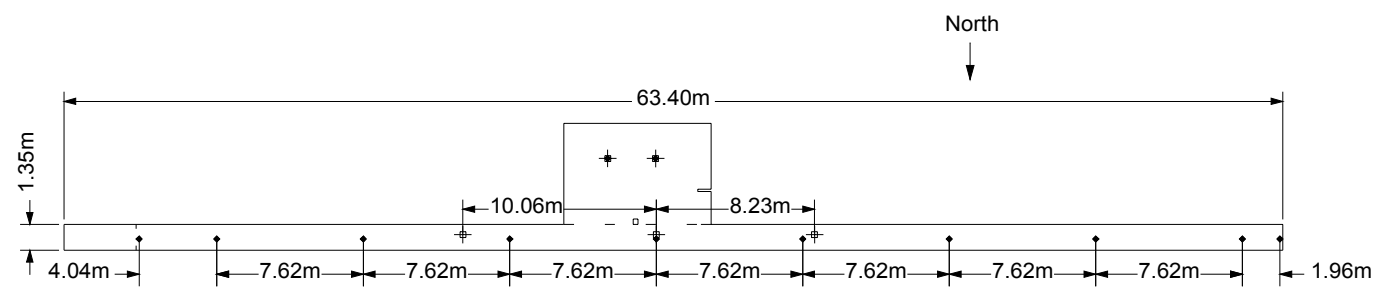

Figure 9. Locations of thermocouple arrays in corridor. 


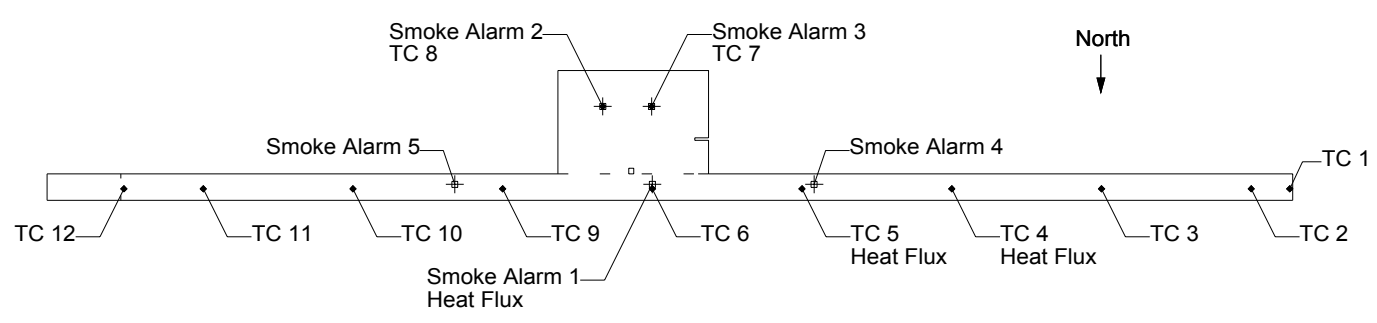

Figure 10. Diagram with instrumentation locations identified 


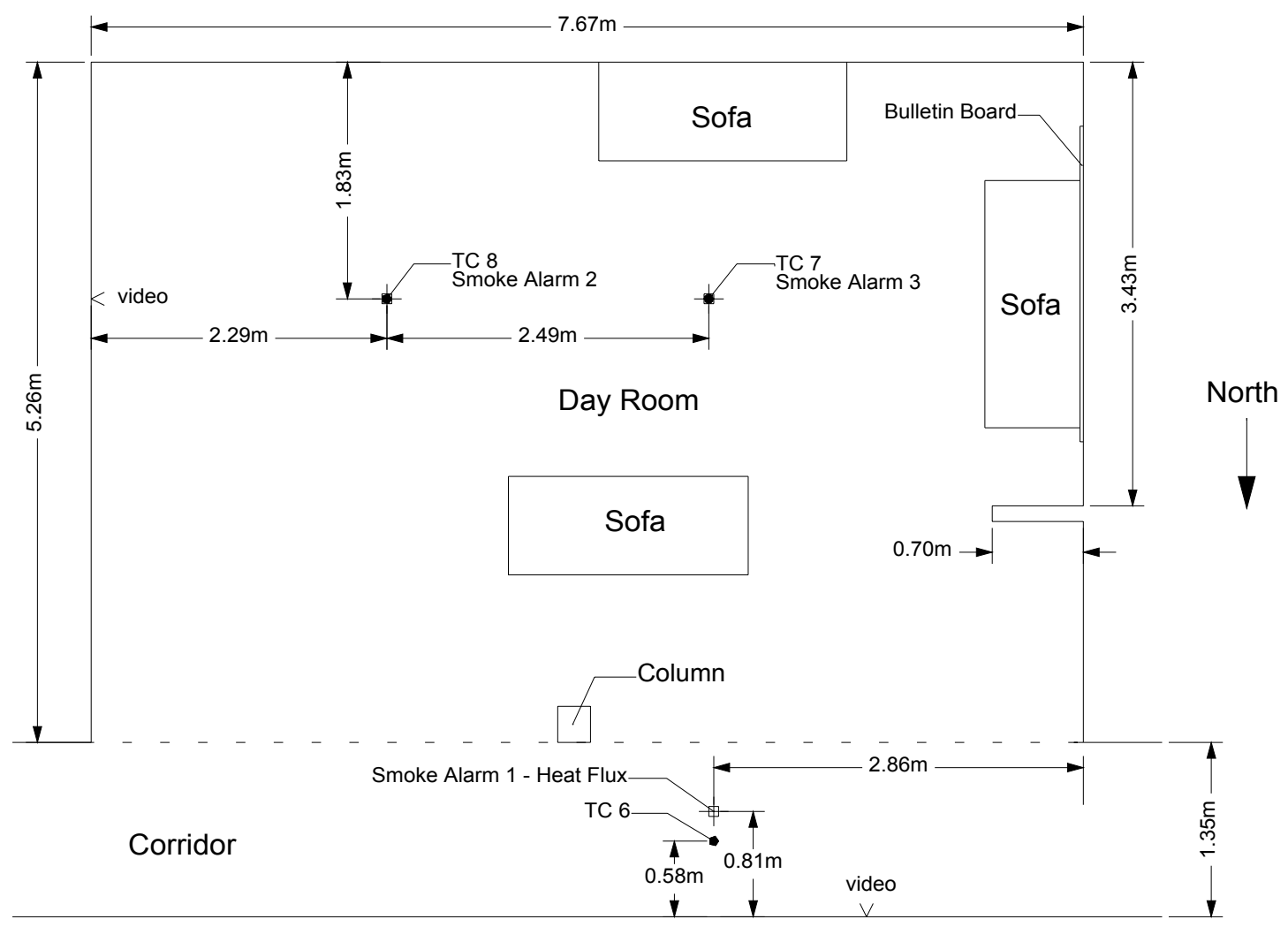

Figure 11. Diagram with instrumentation locations identified in day room area. 


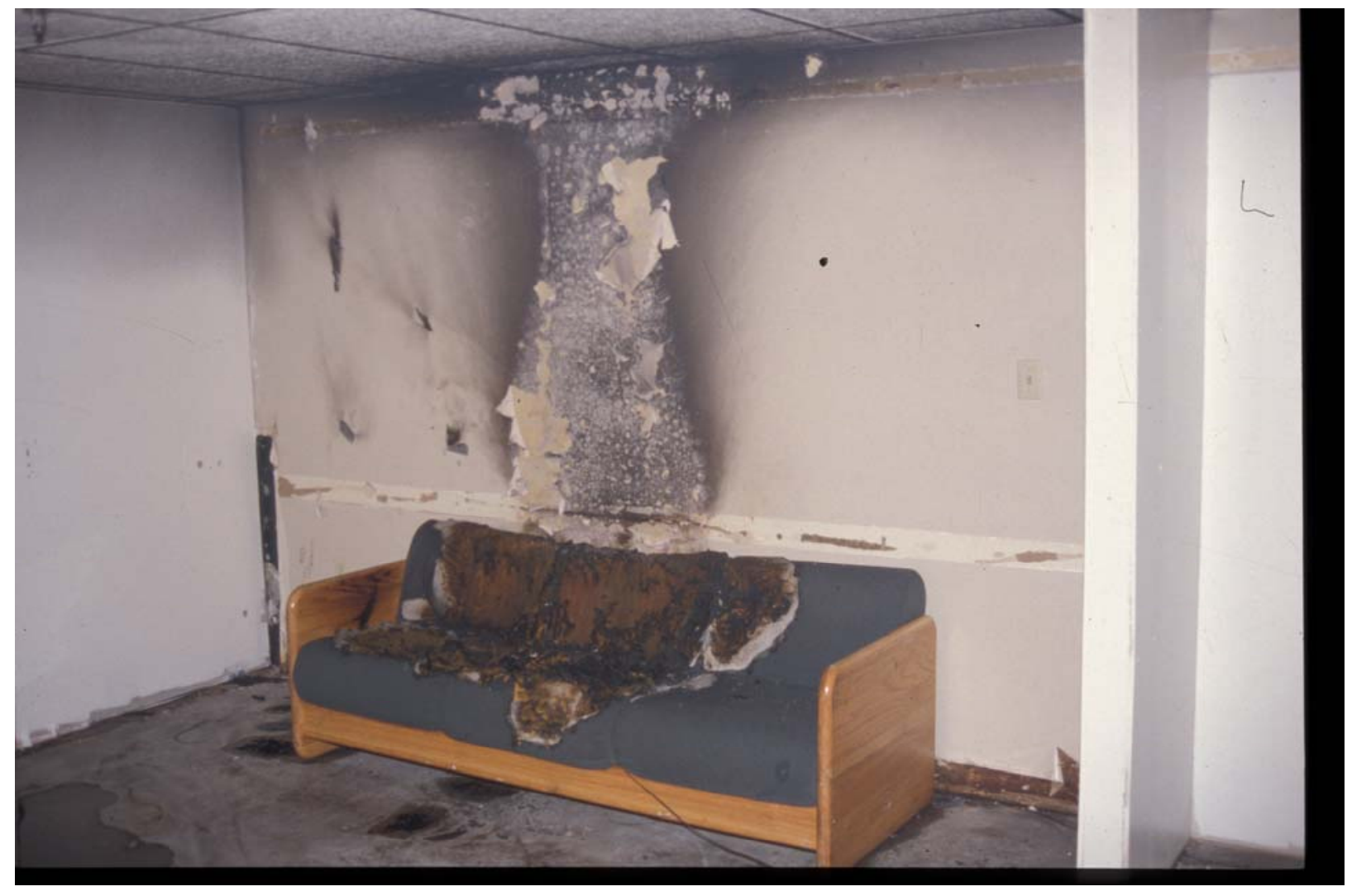

Figure 12. Photograph of day room after experiment 1. 


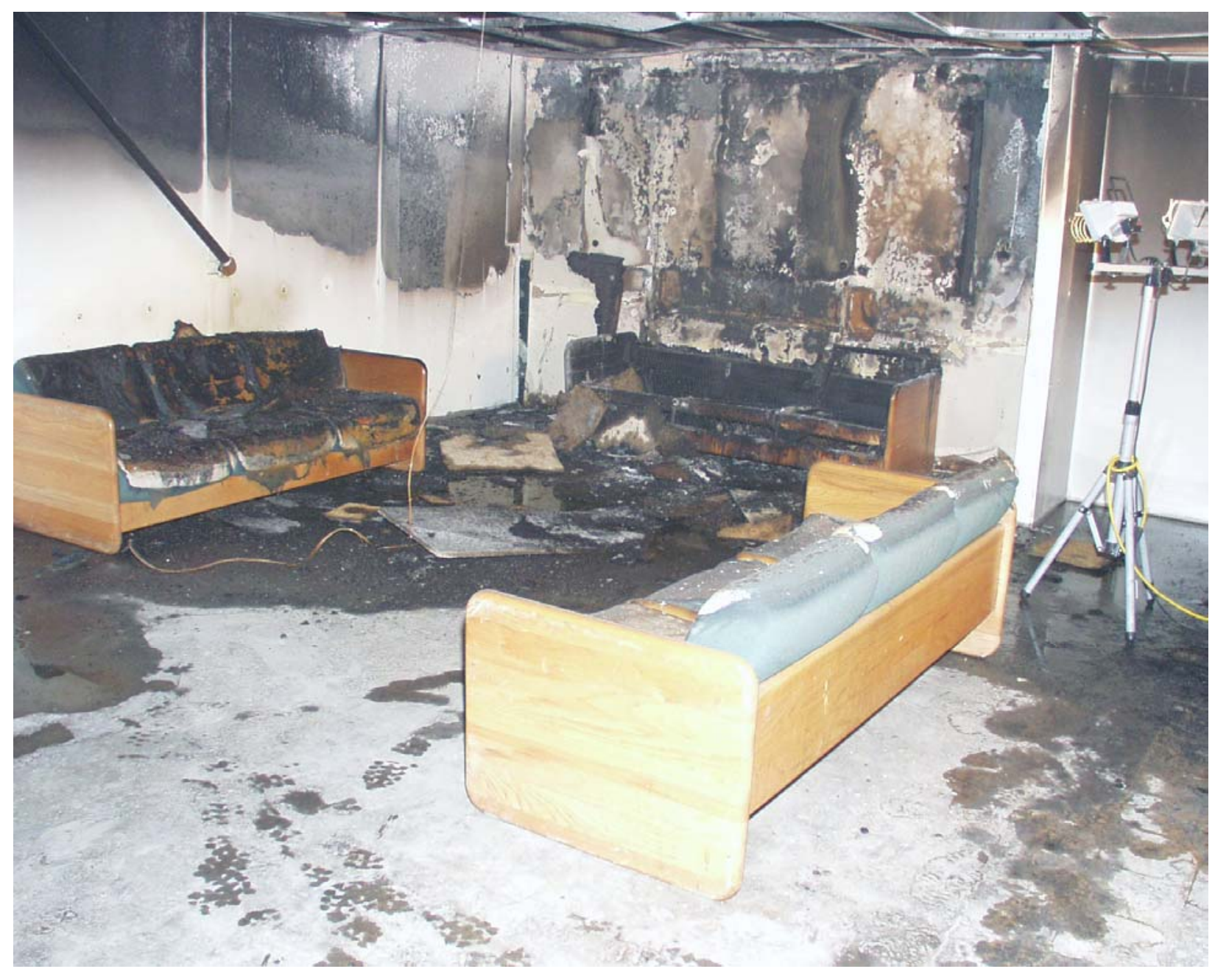

Figure 13. Photograph showing the day room after experiment 2. 


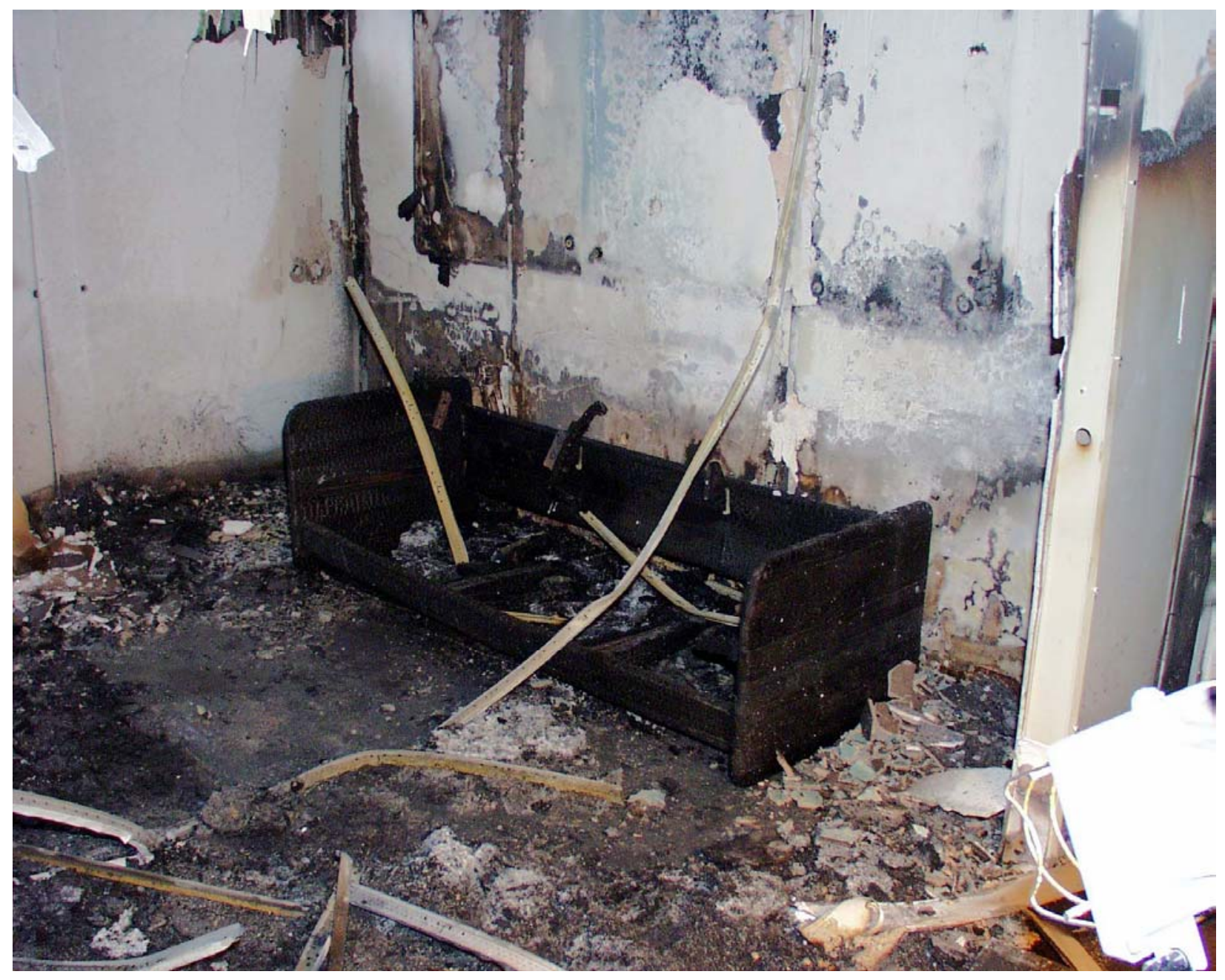

Figure 14. Photograph showing the ignition sofa after experiment 3. 


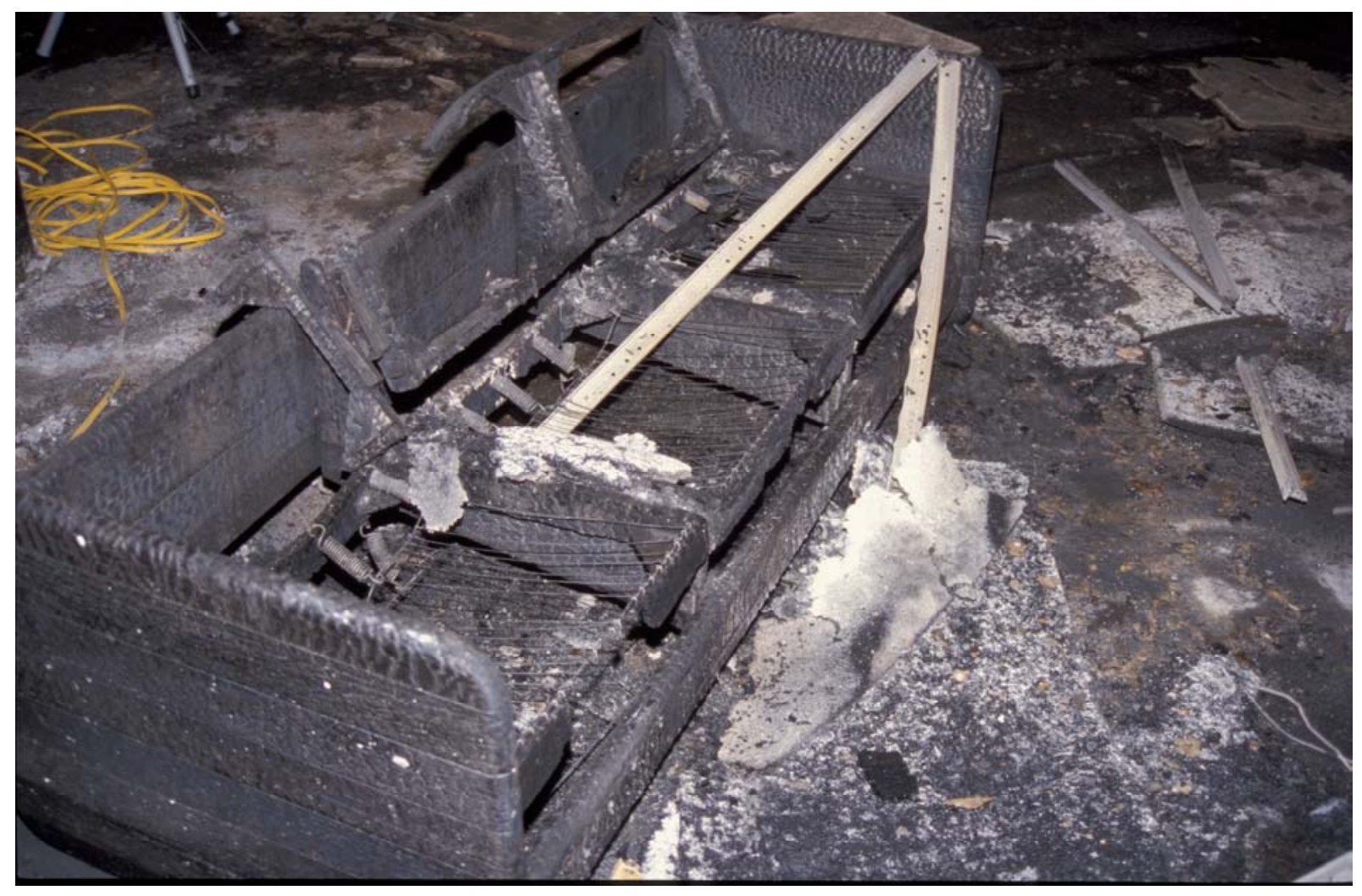

Figure 15. Photograph of north sofa after experiment 3. 


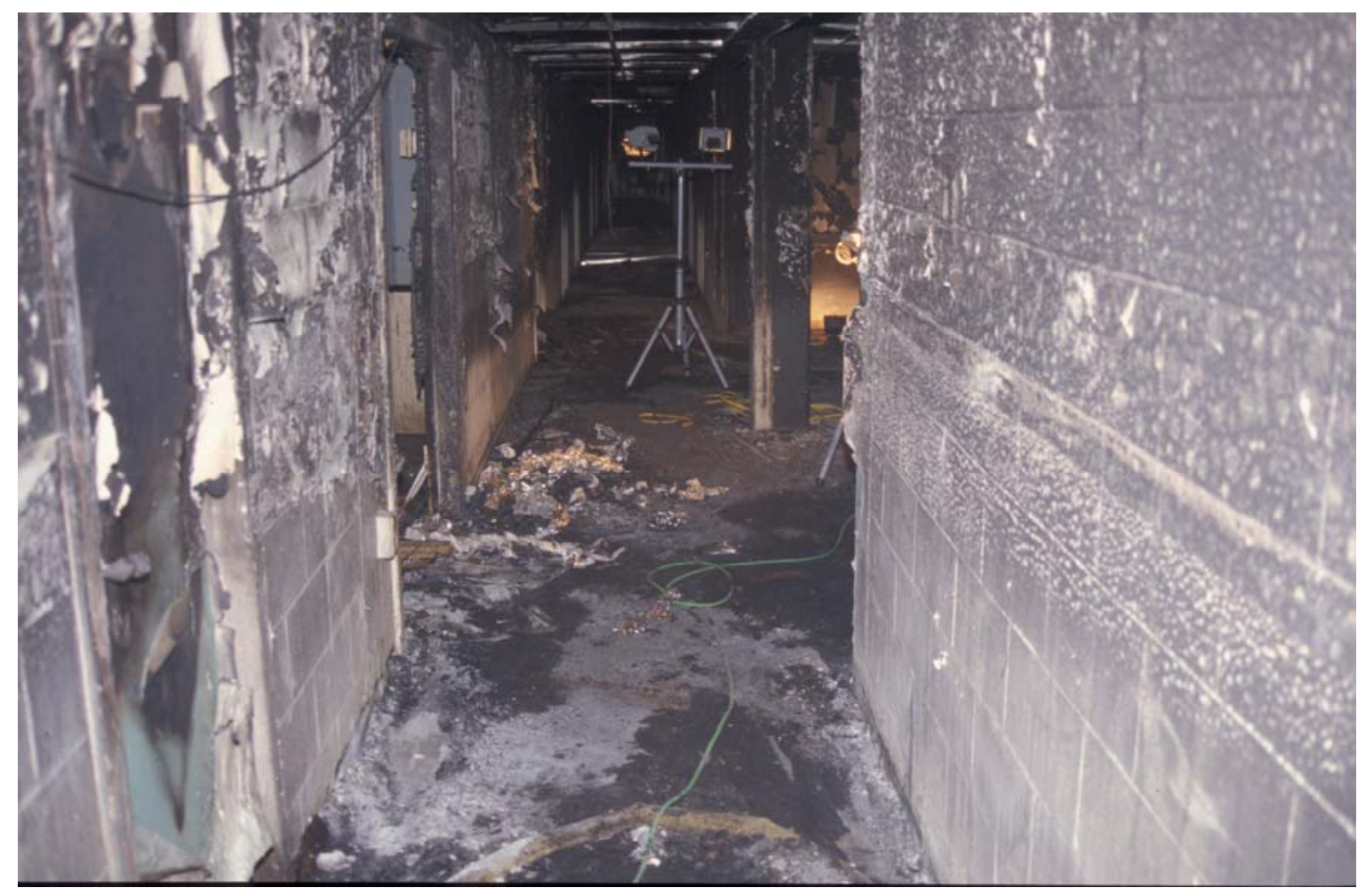

Figure 16. Photograph of corridor from the west approaching day room on right, after experiment 3 . 

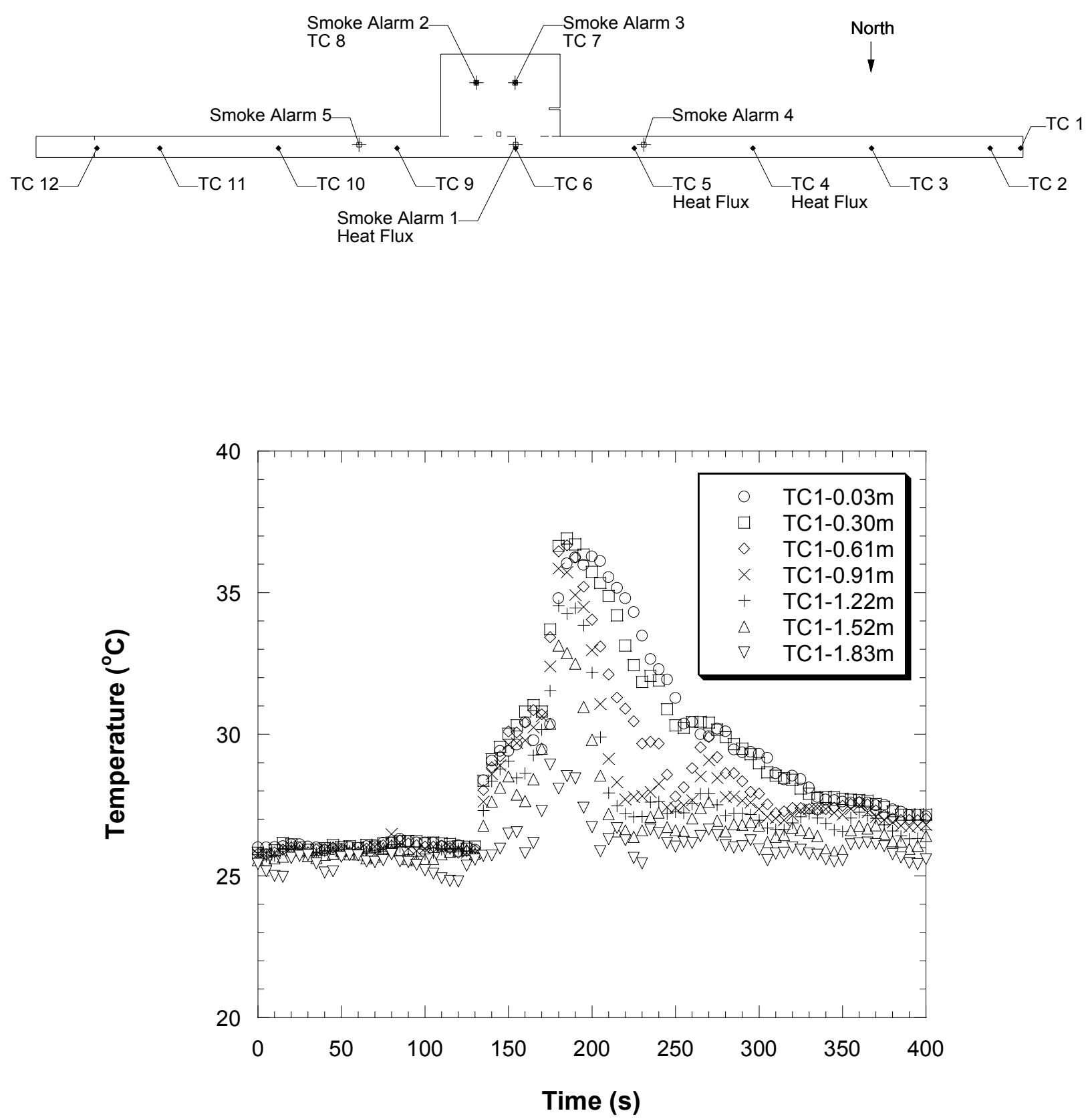

Figure 17 Experiment 1, corridor temperatures, TC array 1 

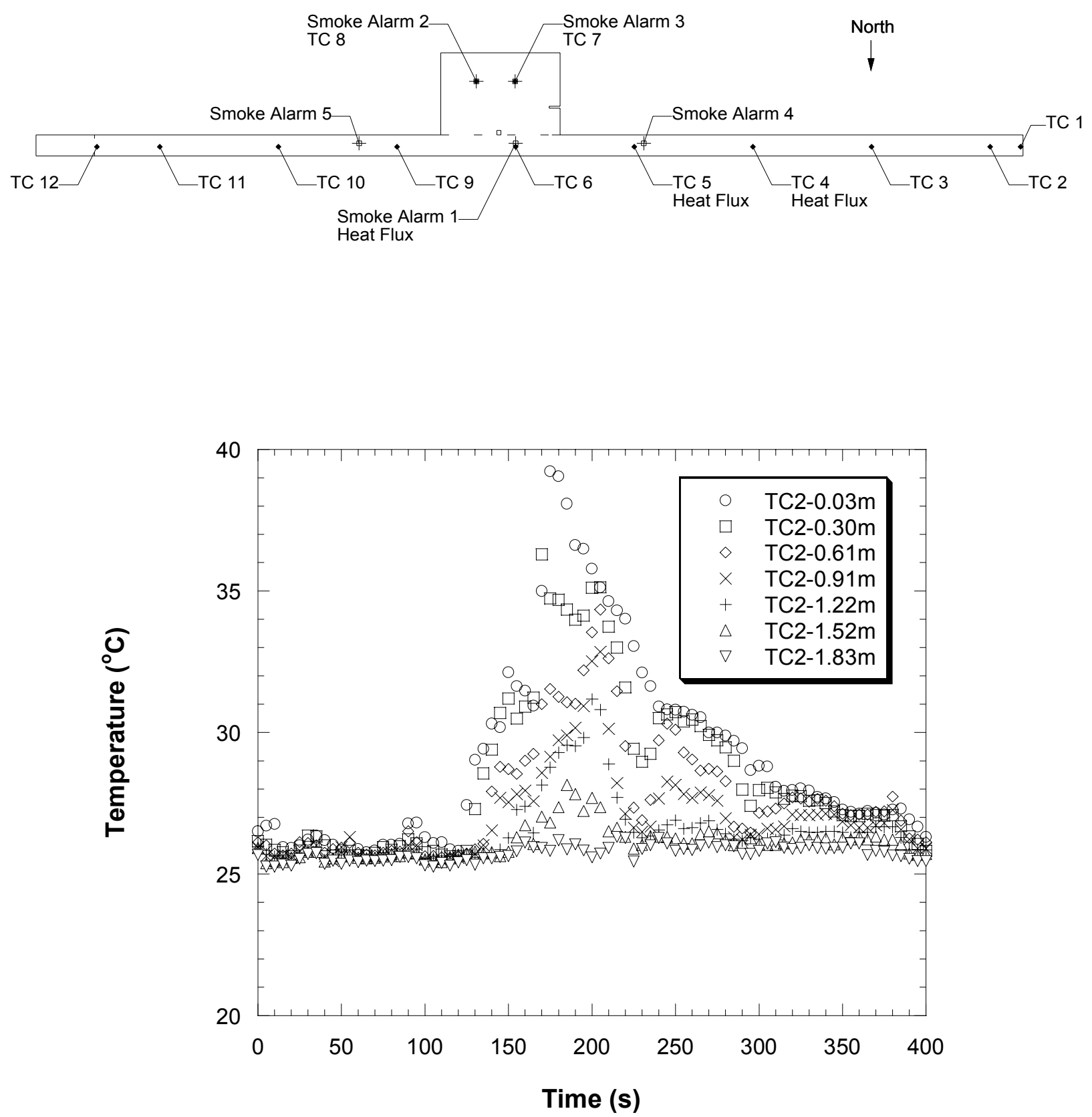

Figure 18 Experiment 1, corridor temperatures, TC array 2 

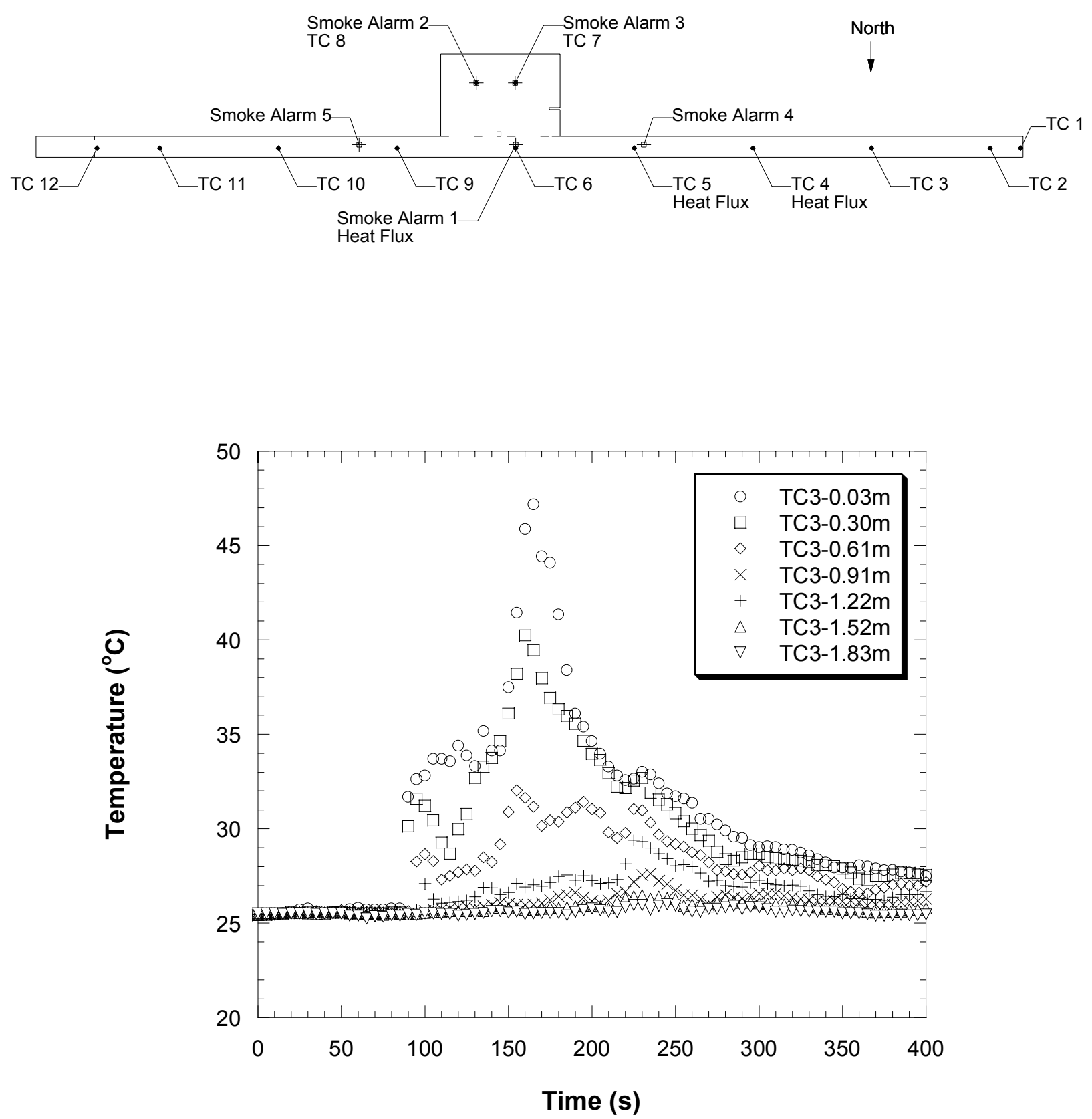

Figure 19 Experiment 1, corridor temperatures, TC array 3 

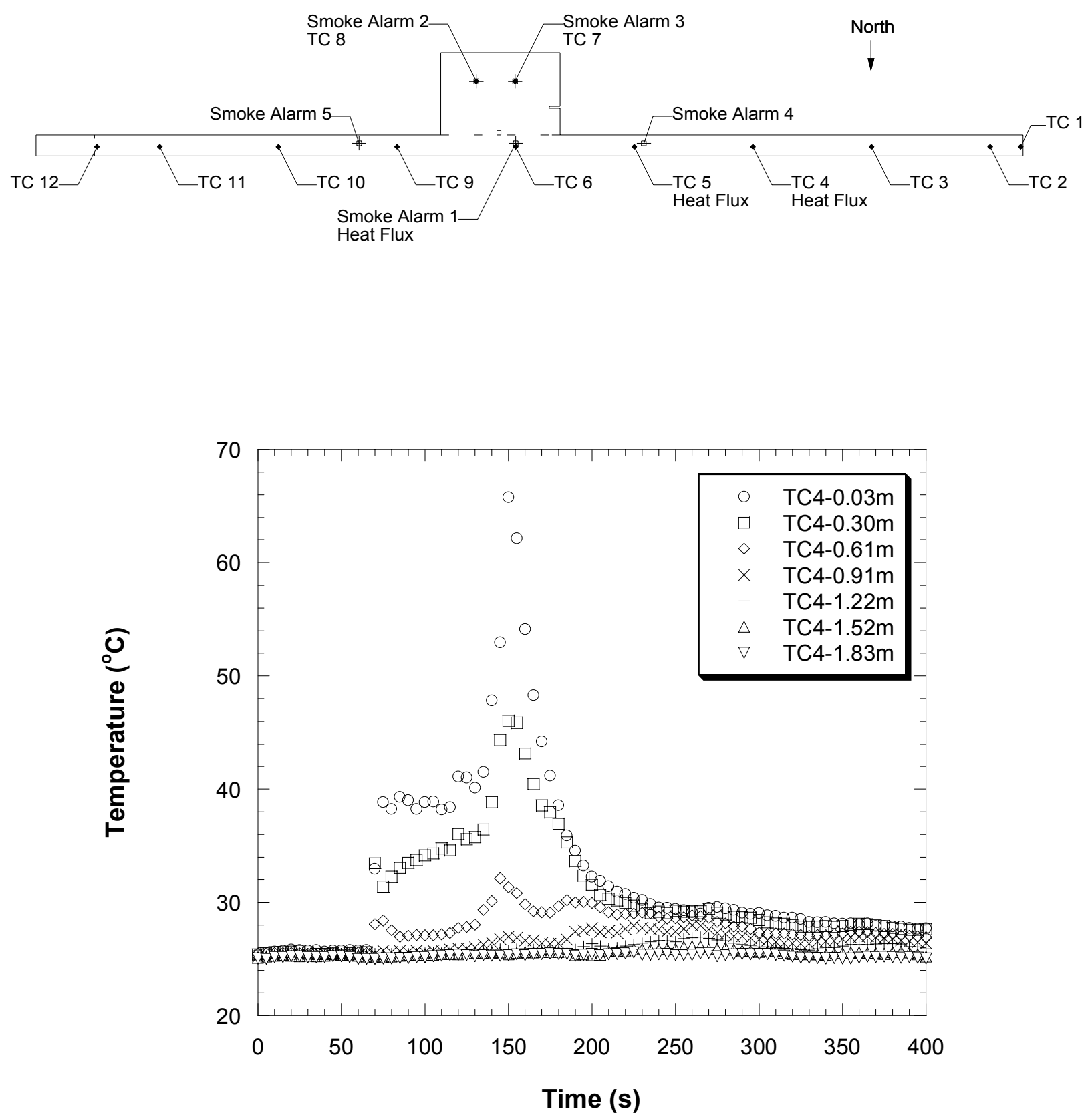

Figure 20 Experiment 1, corridor temperatures, TC array 4 

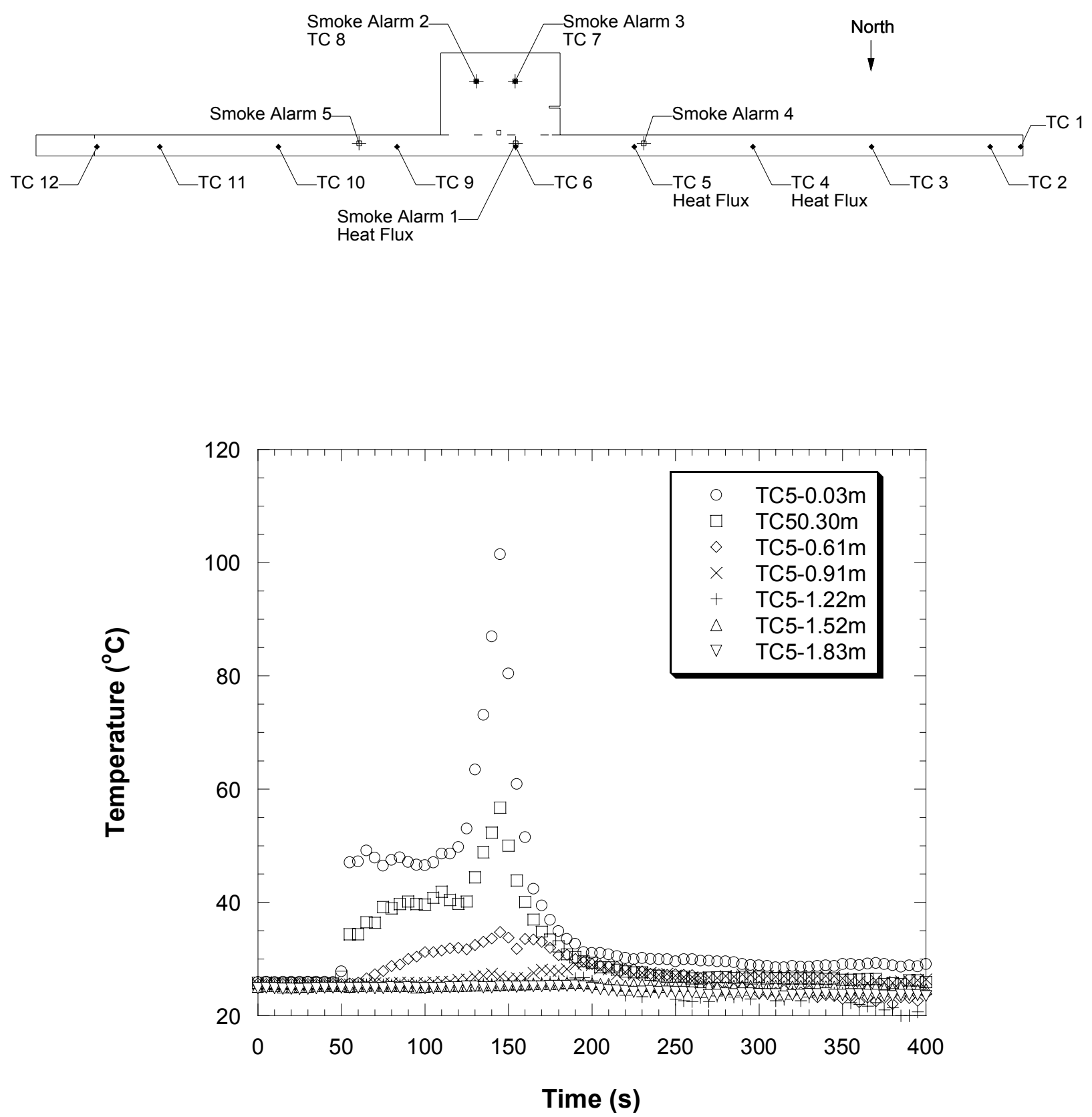

Figure 21 Experiment 1, corridor temperatures, TC array 5 

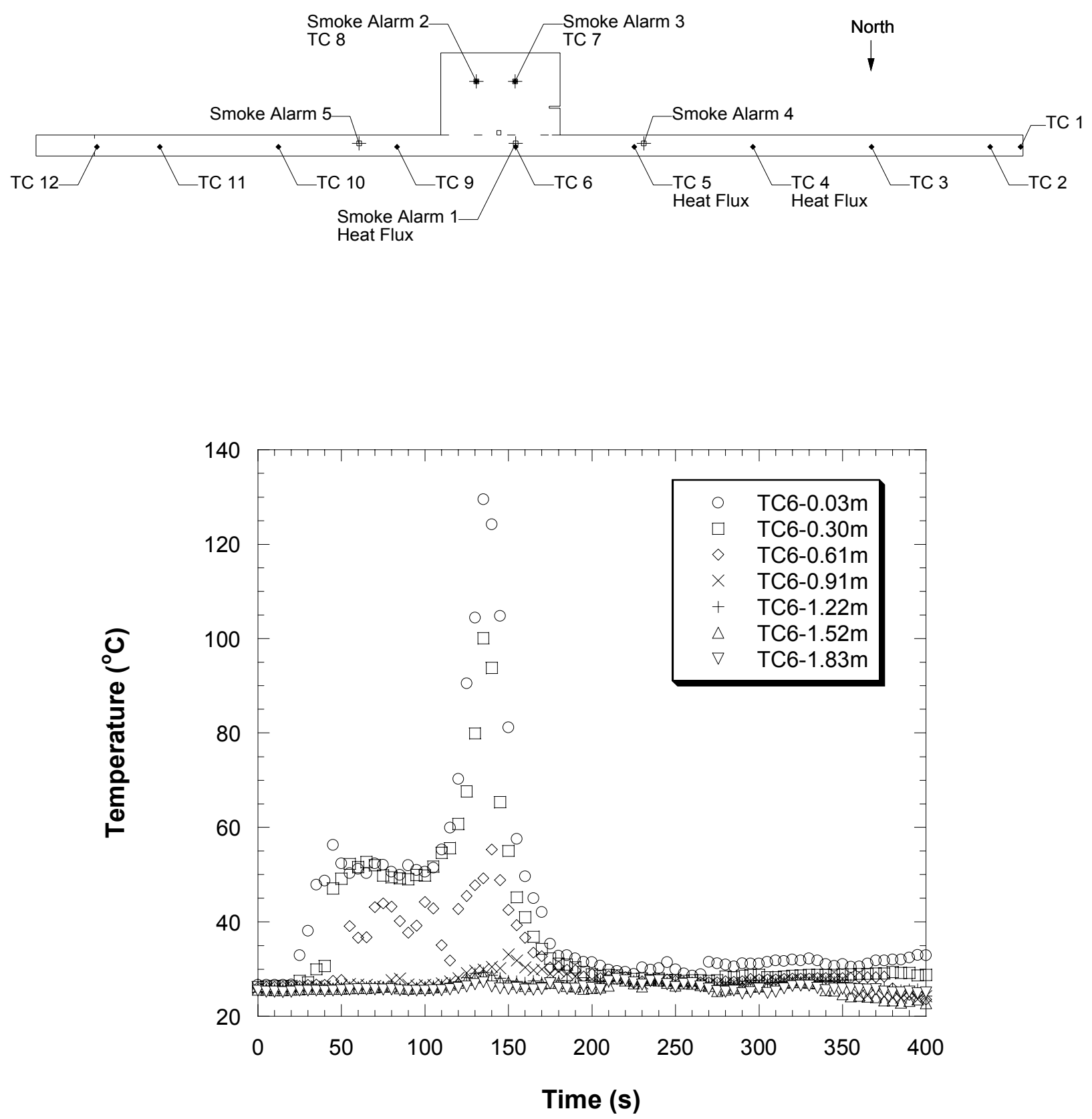

Figure 22 Experiment 1, corridor temperatures, TC array 6 

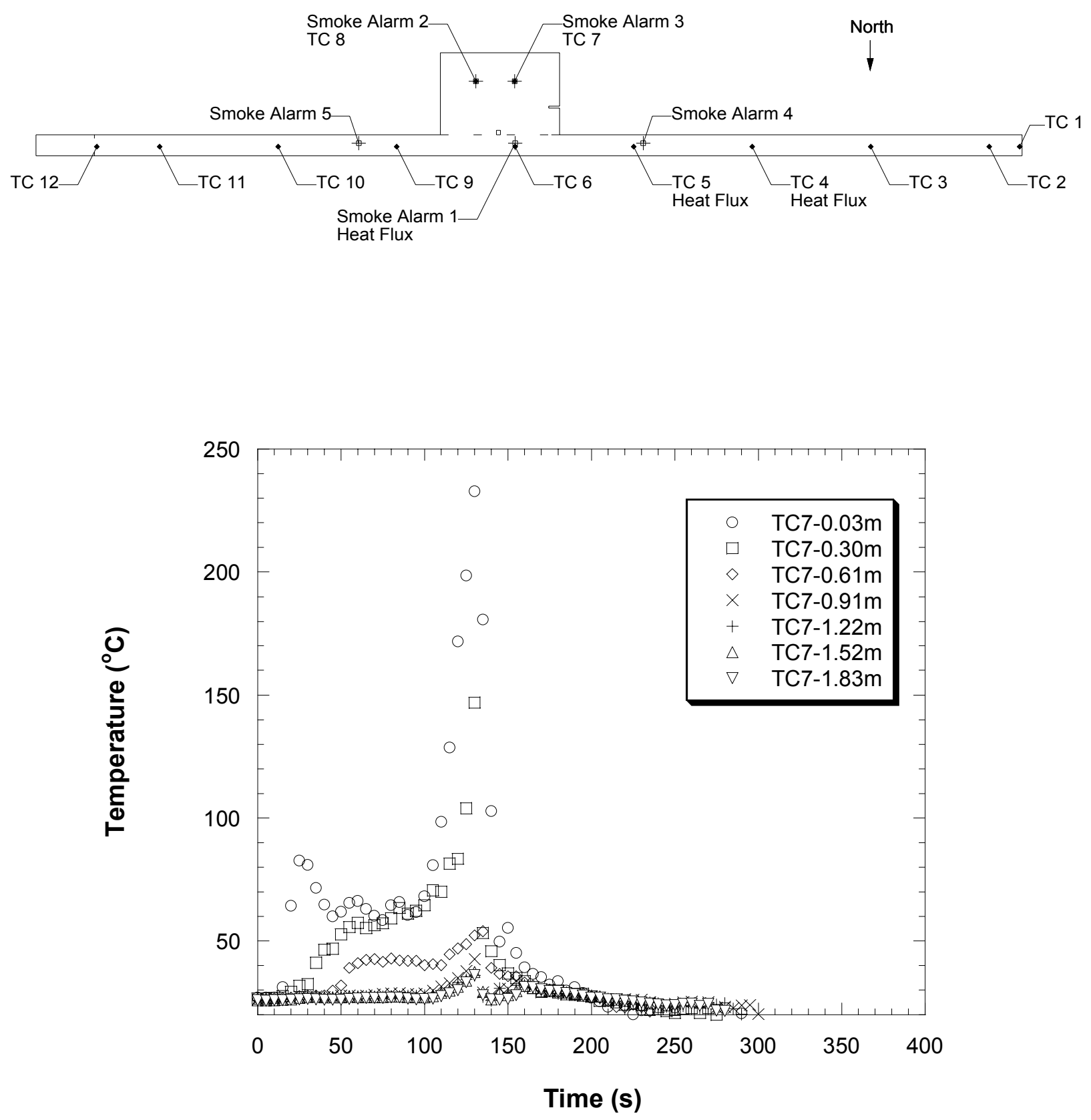

Figure 23 Experiment 1, dayroom temperatures, west side near ignition, TC array 7 

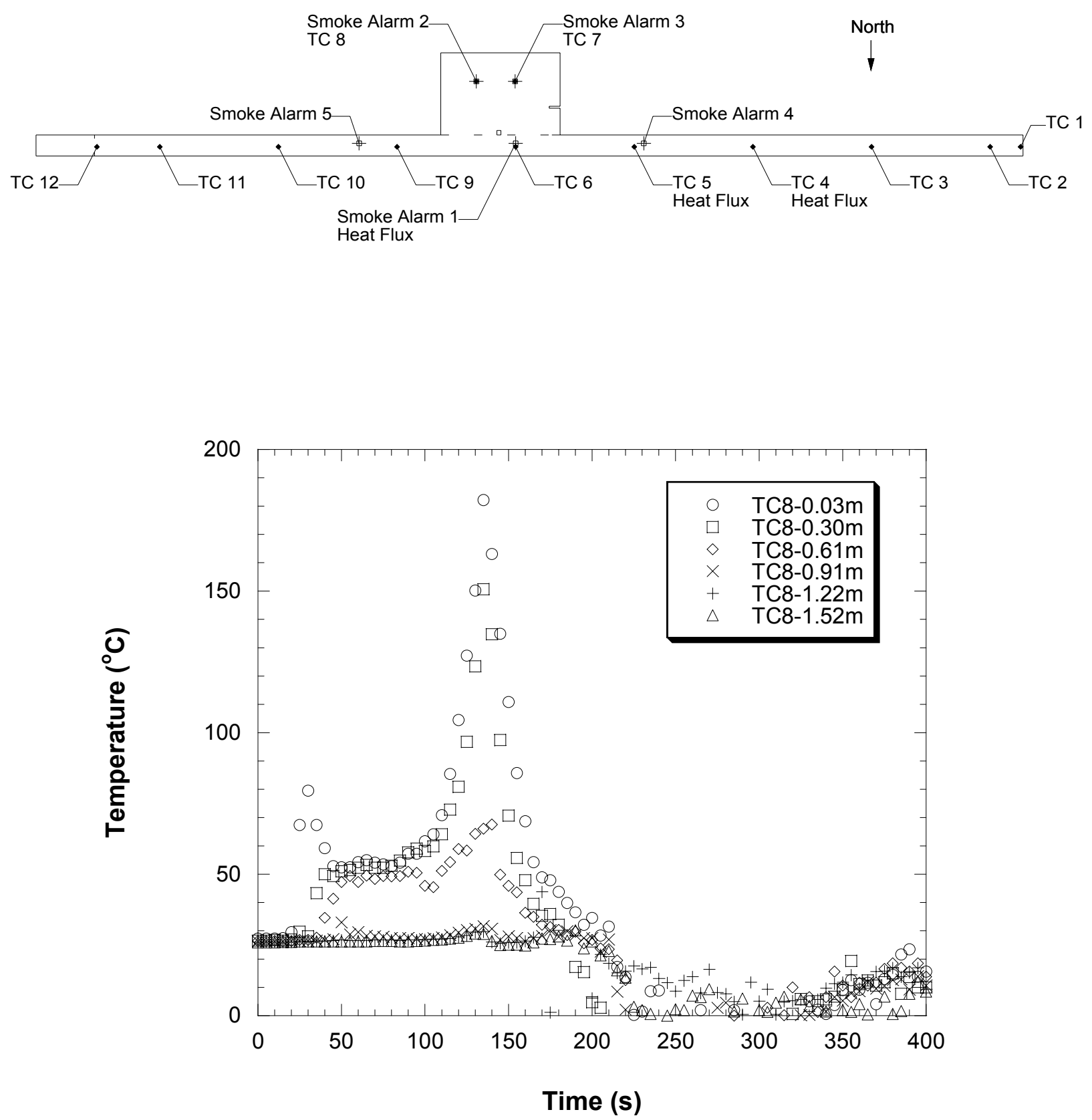

Figure 24 Experiment 1, dayroom temperatures, east side, TC array 8 

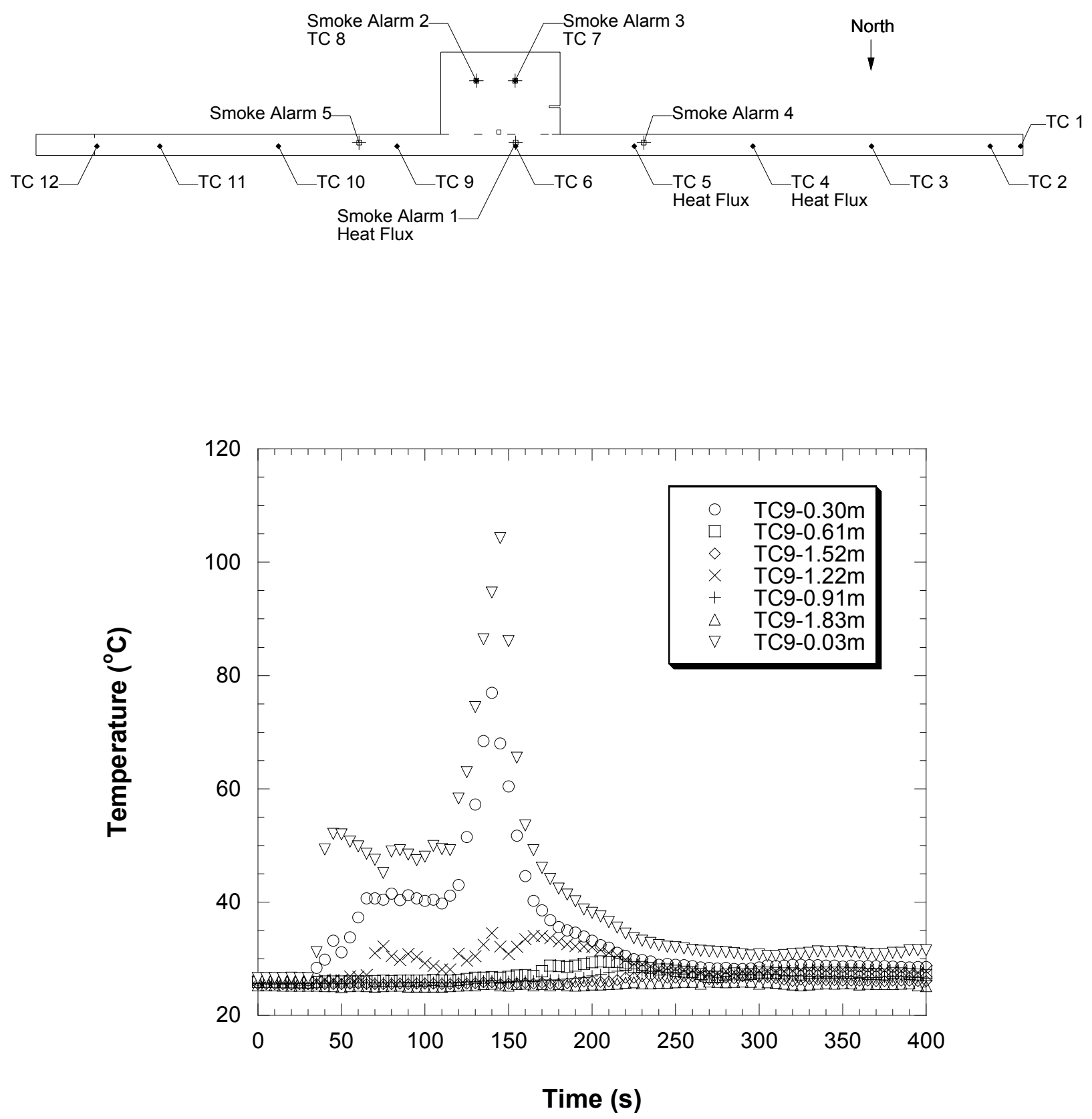

Figure 25 Experiment 1, corridor temperatures, TC array 9 

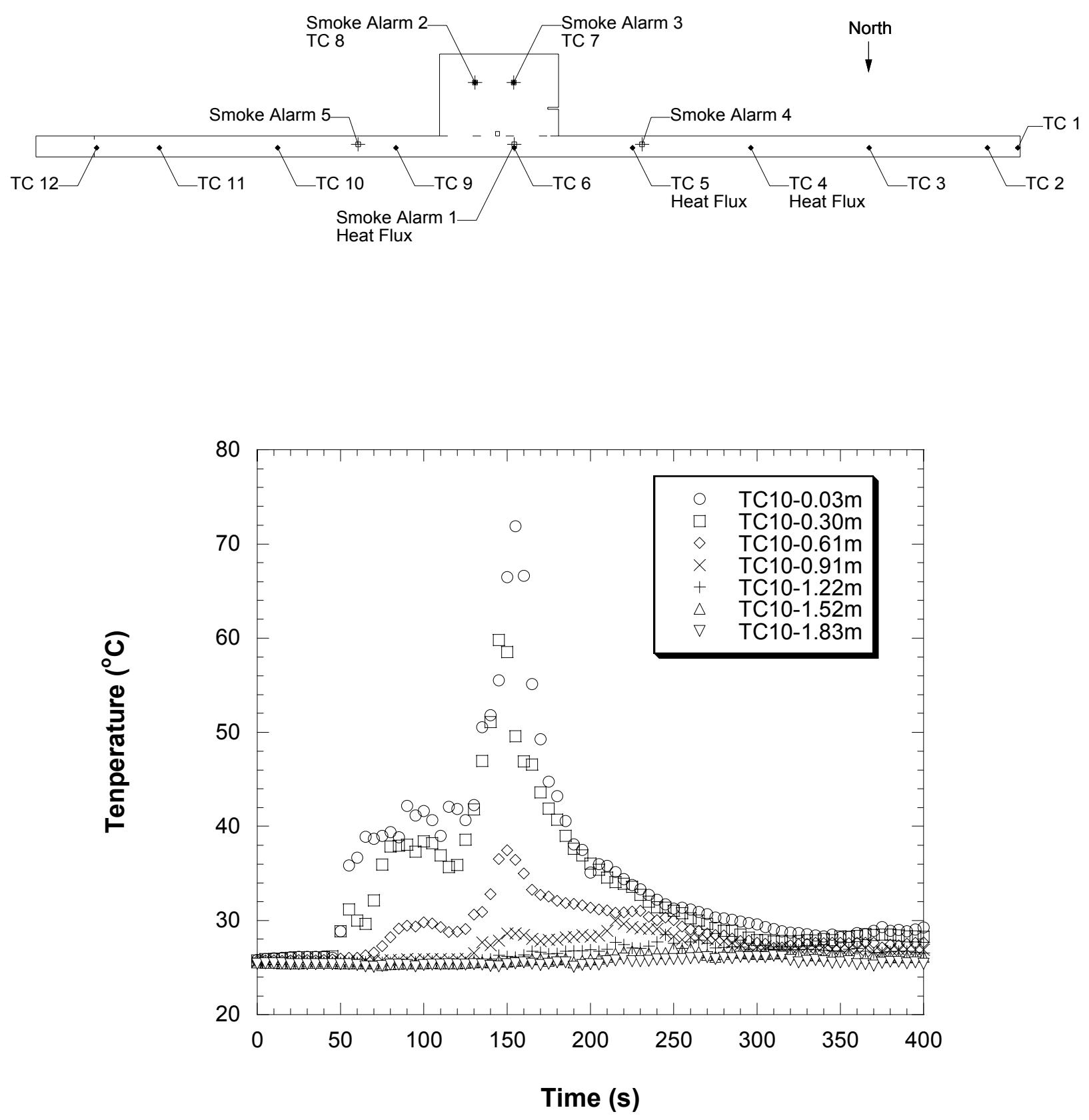

Figure 26 Experiment 1, corridor temperatures, TC array 10 

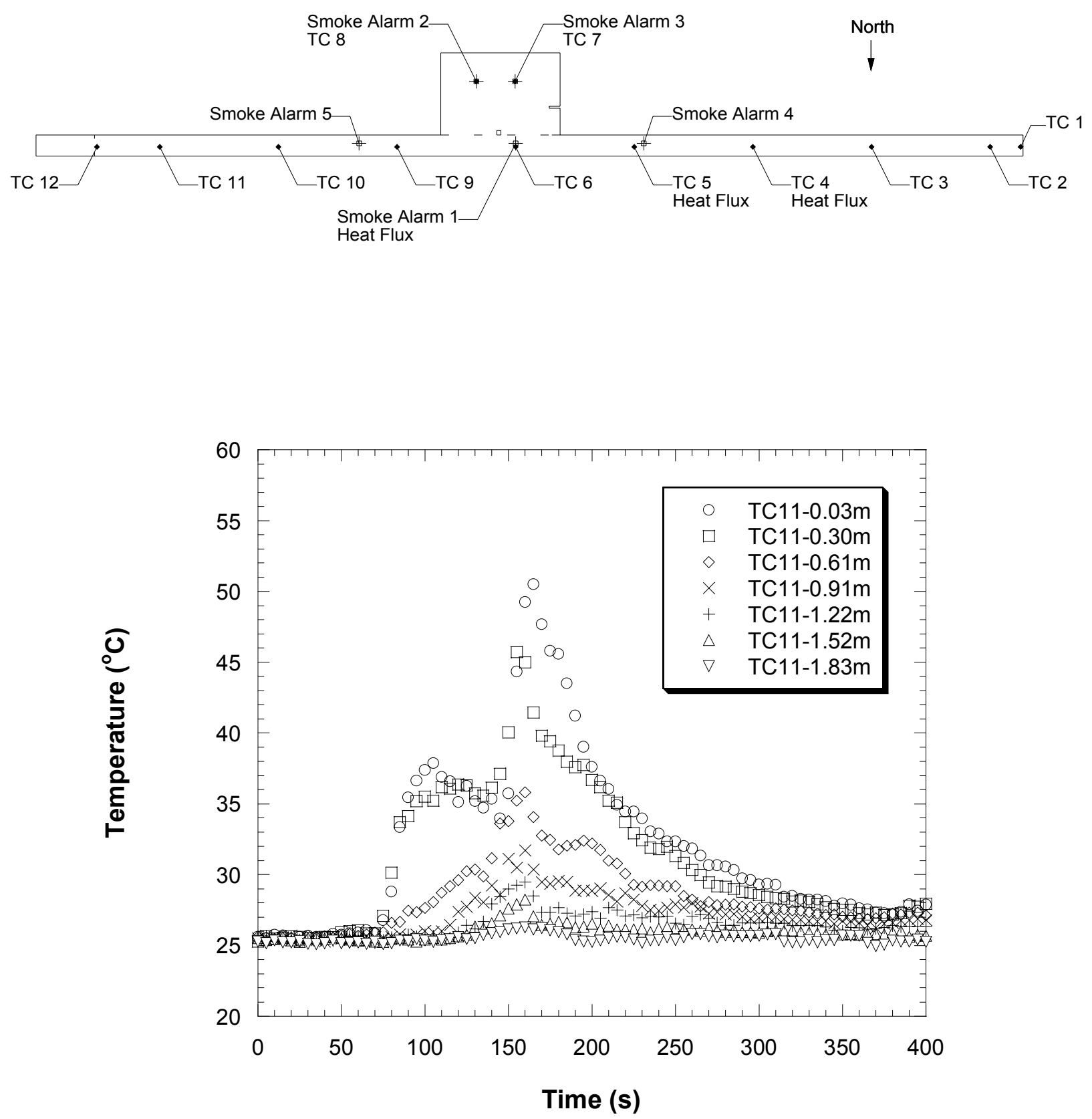

Figure 27 Experiment 1, corridor temperatures, TC array 11 

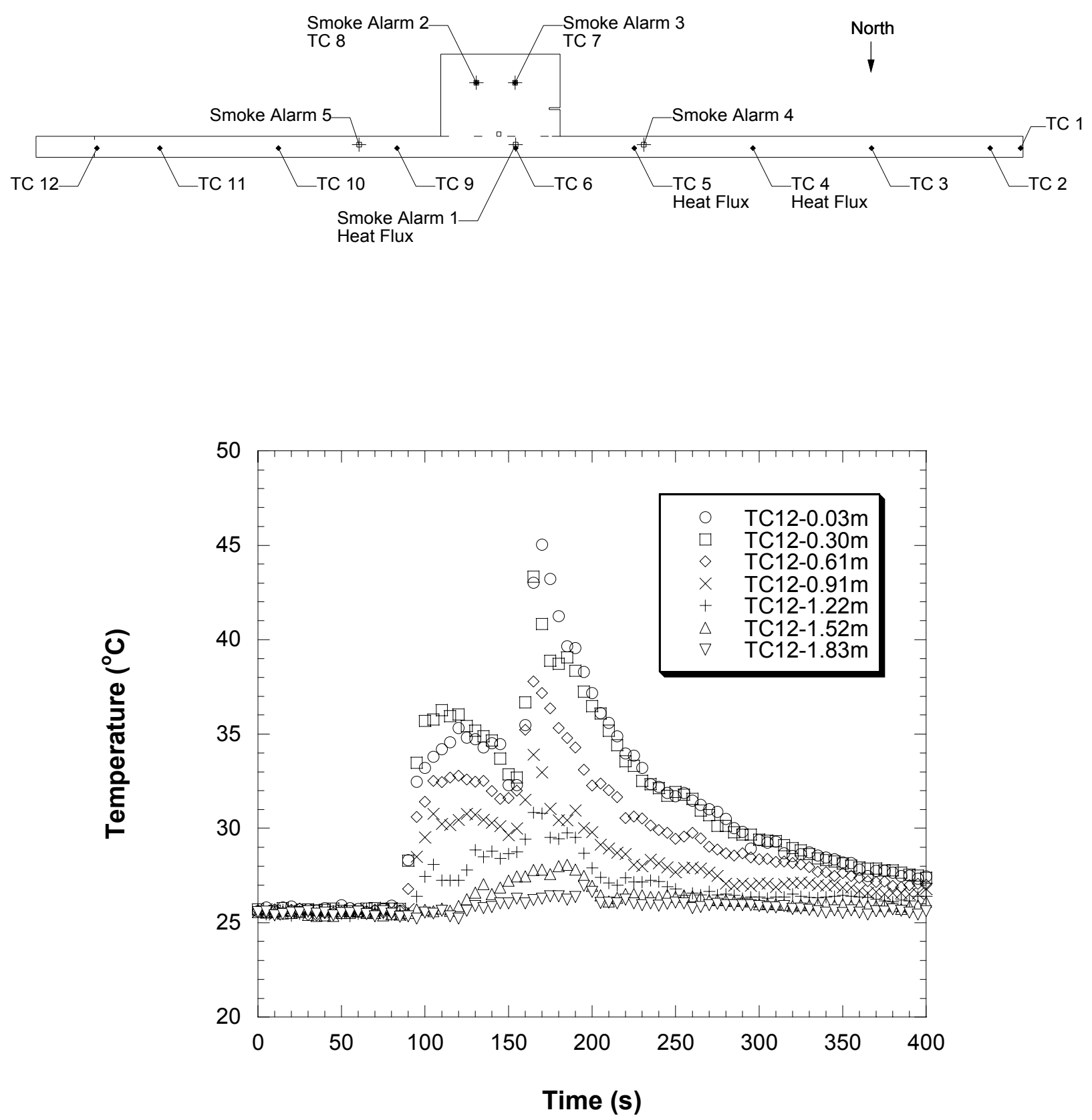

Figure 28 Experiment 1, corridor temperatures, TC array 12 

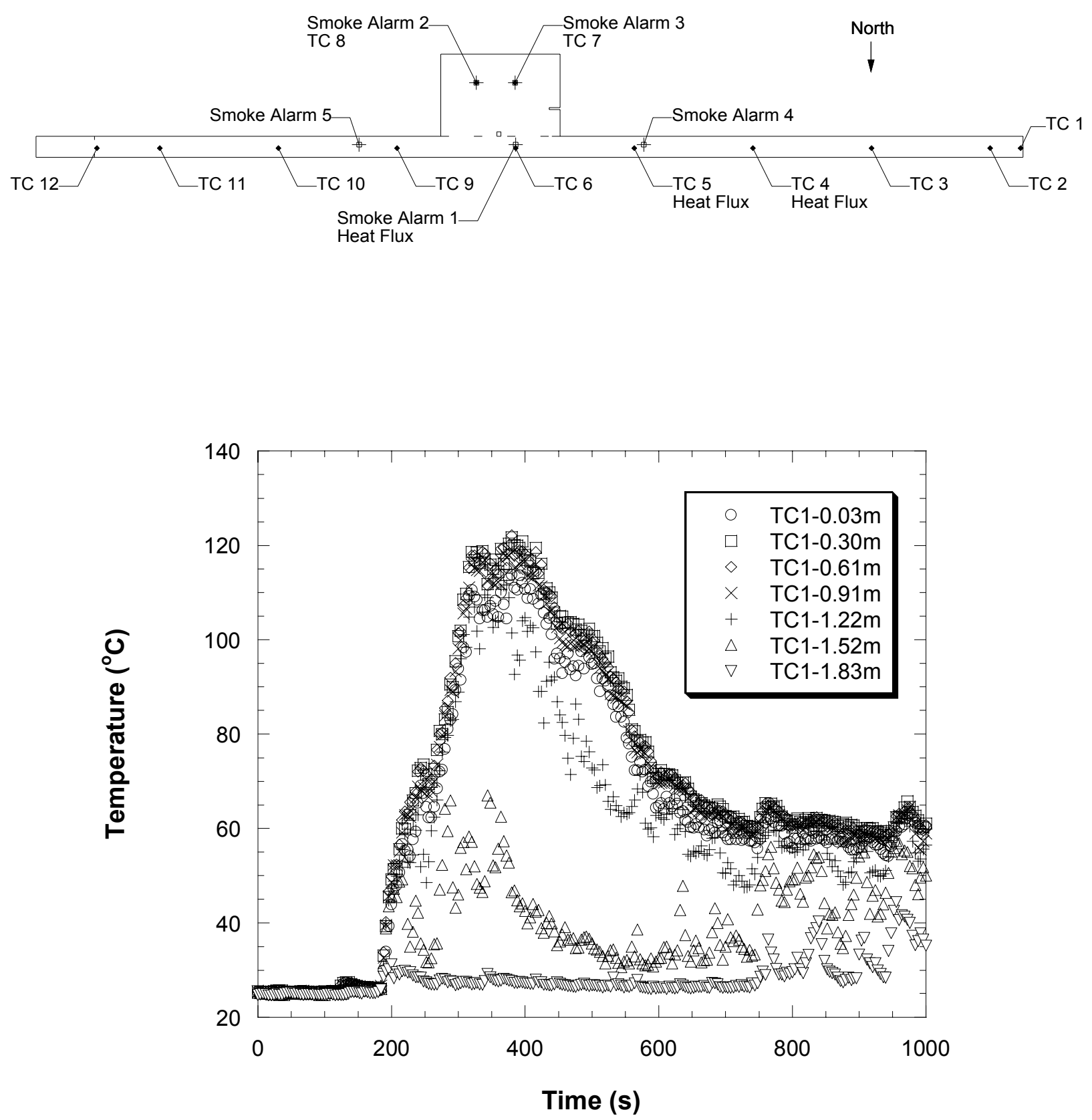

Figure 29 Experiment 2, corridor temperatures, TC array 1 

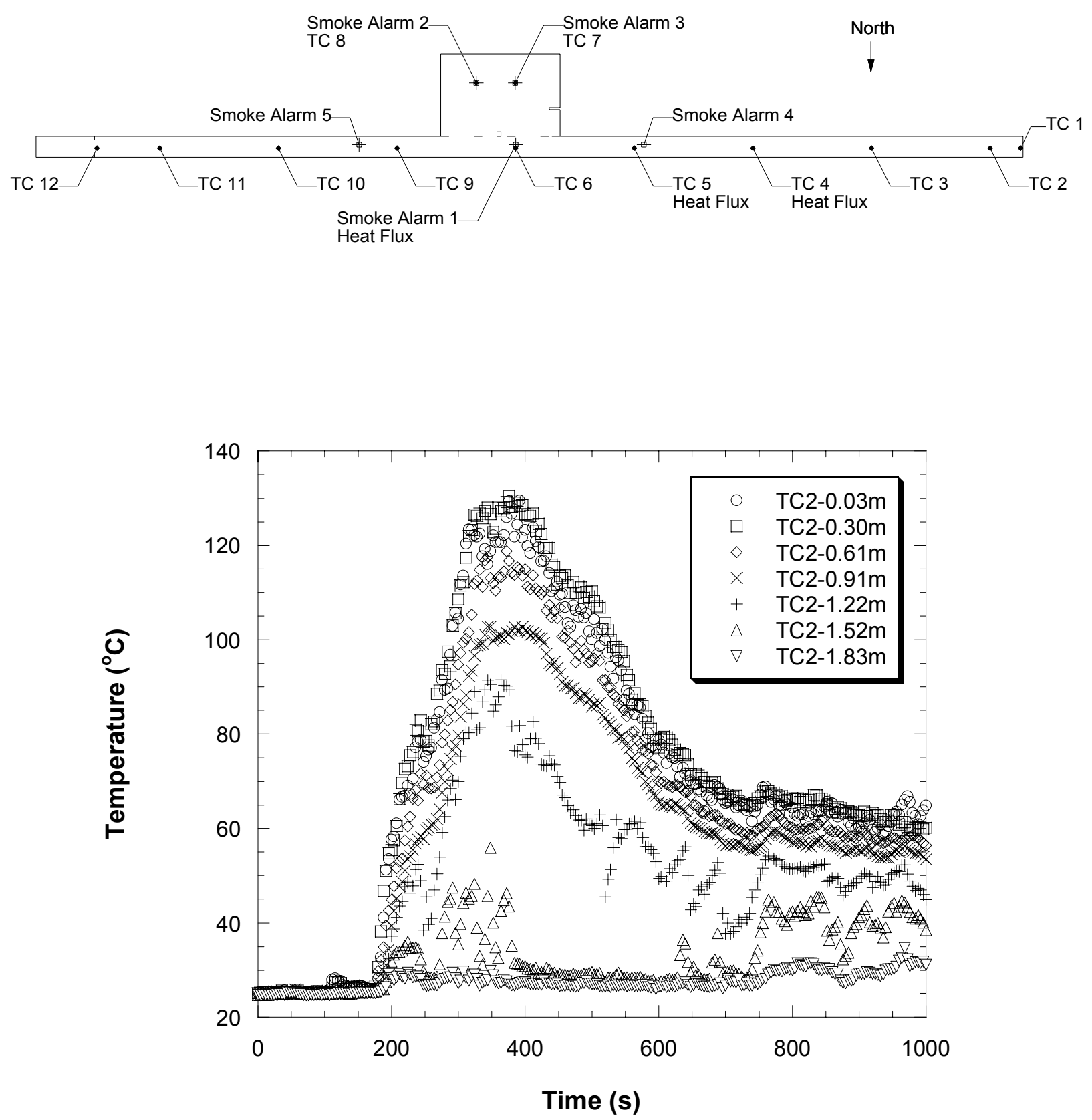

Figure 30 Experiment 2, corridor temperatures, TC array 2 

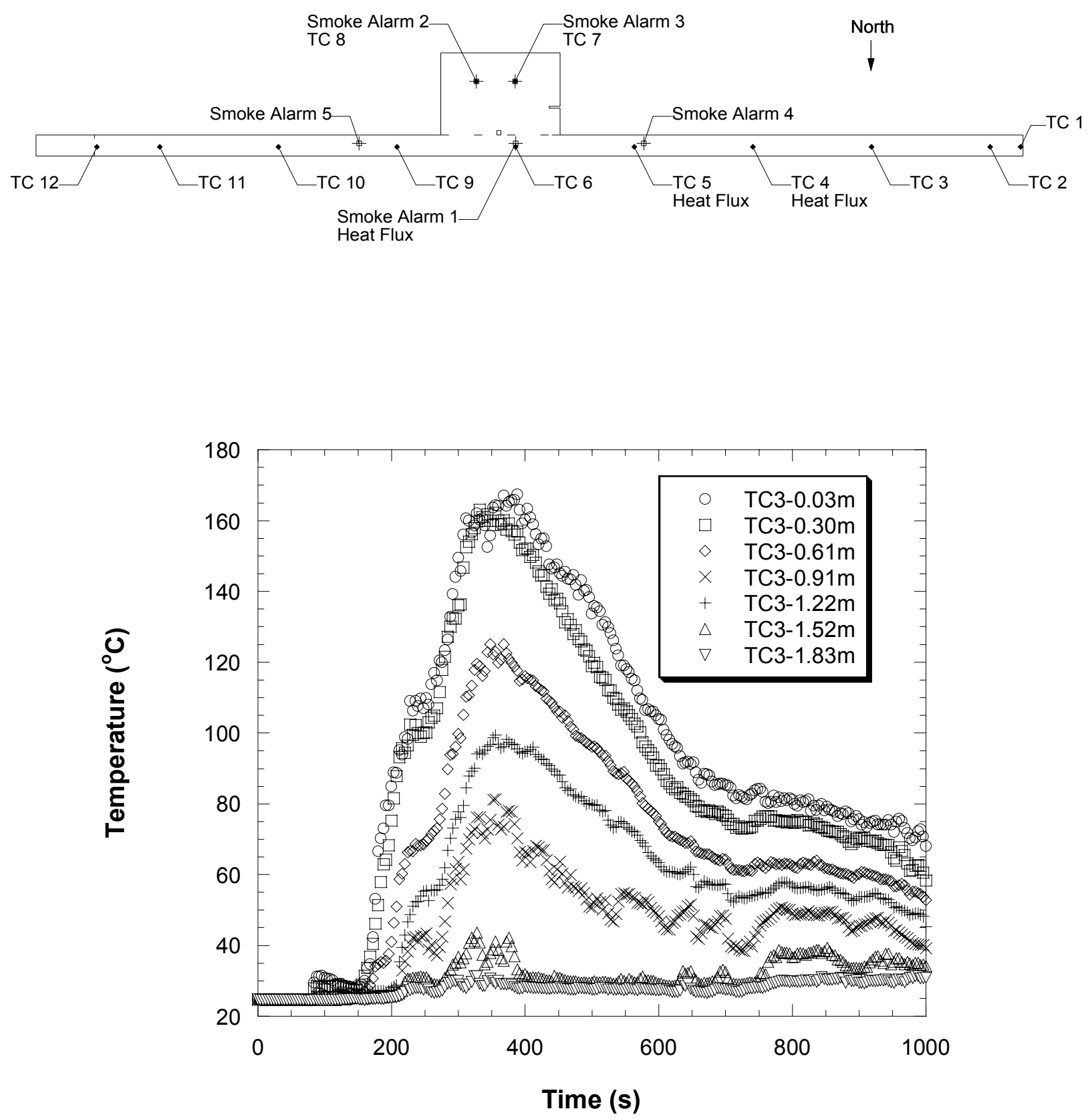

Figure 31 Experiment 2, corridor temperatures, TC array 3 

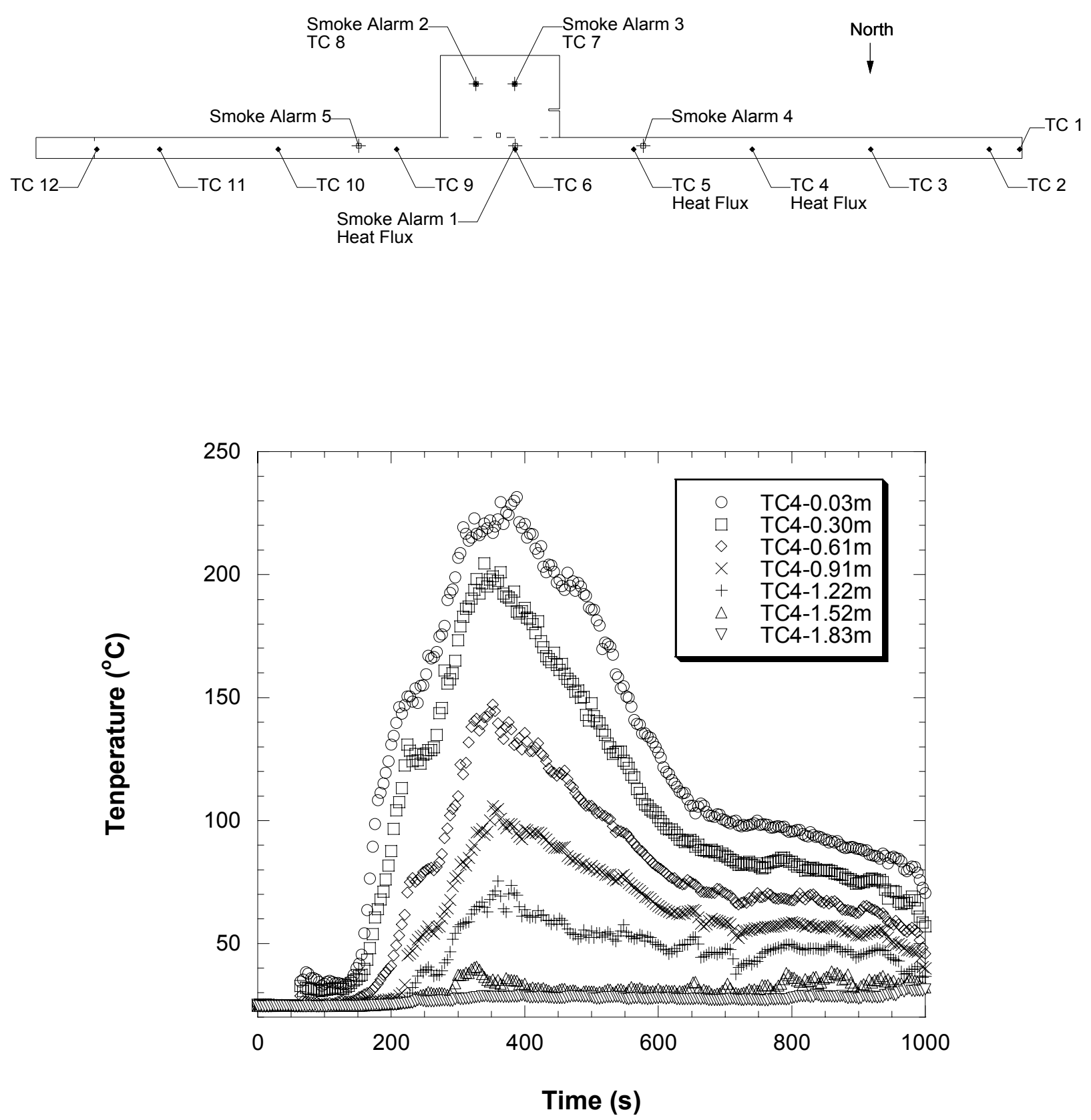

Figure 32 Experiment 2, corridor temperatures, TC array 4 

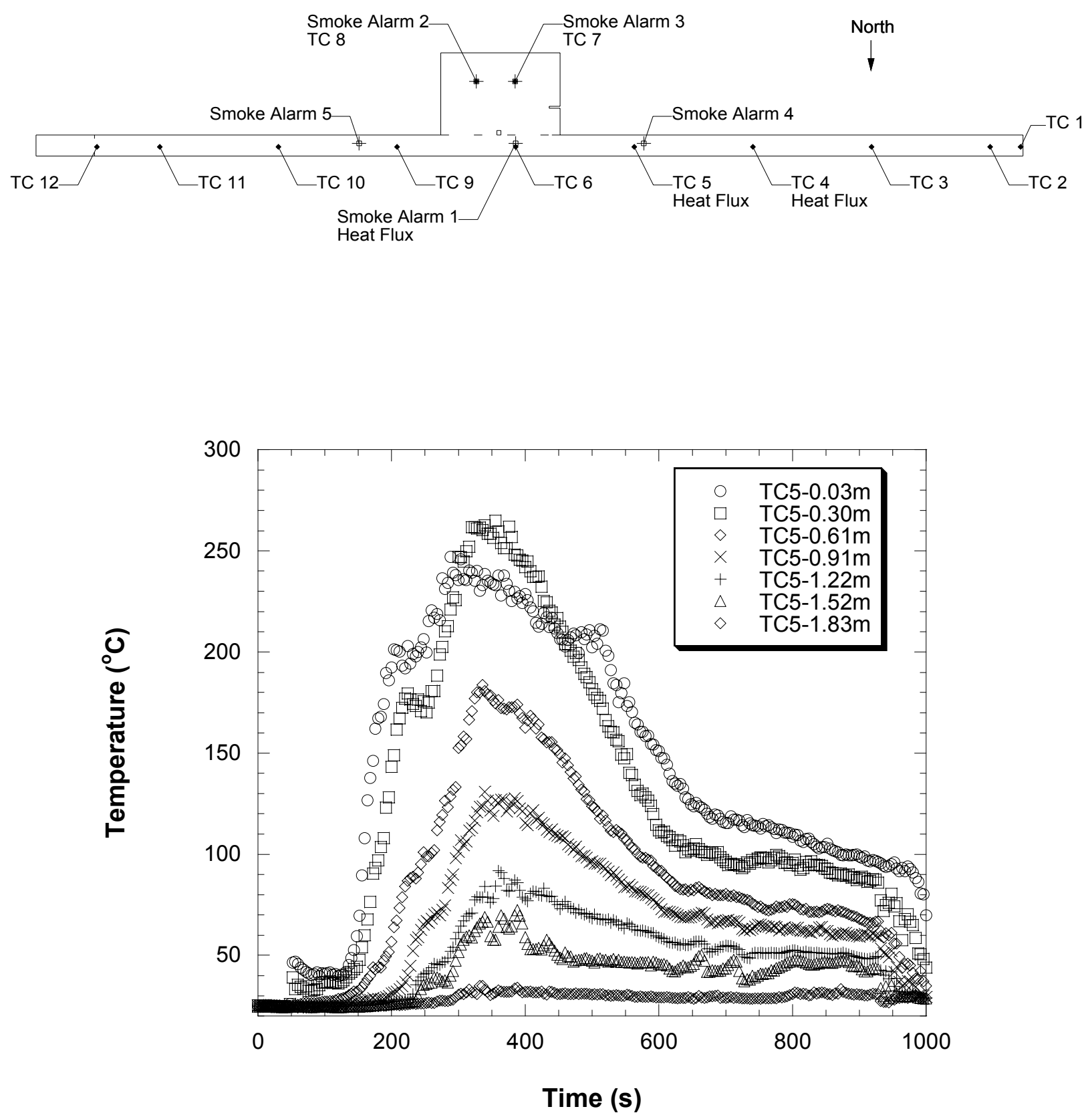

Figure 33 Experiment 2, corridor temperatures, TC array 5 

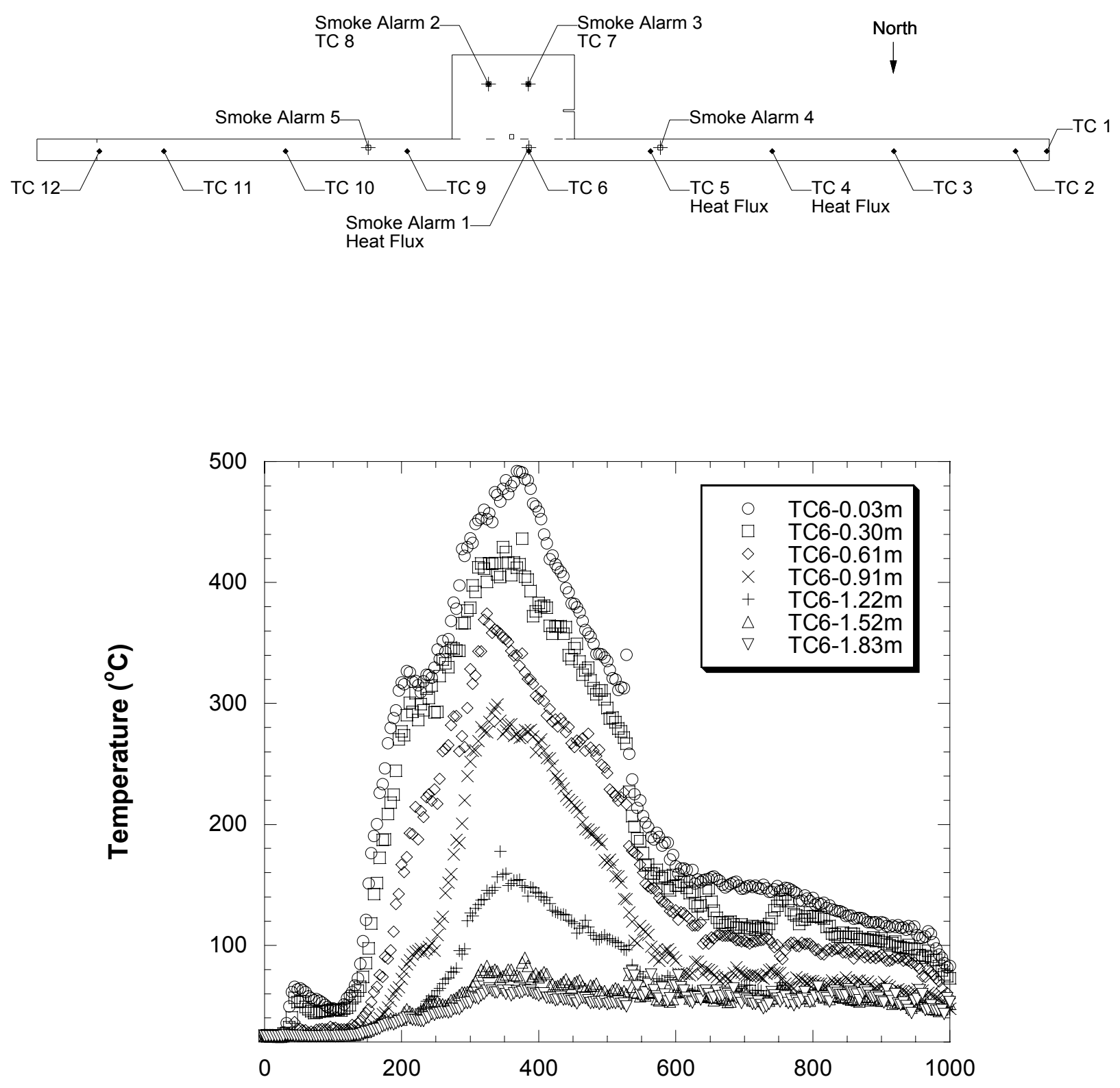

Figure 34 Experiment 2, corridor temperatures, TC array 6 

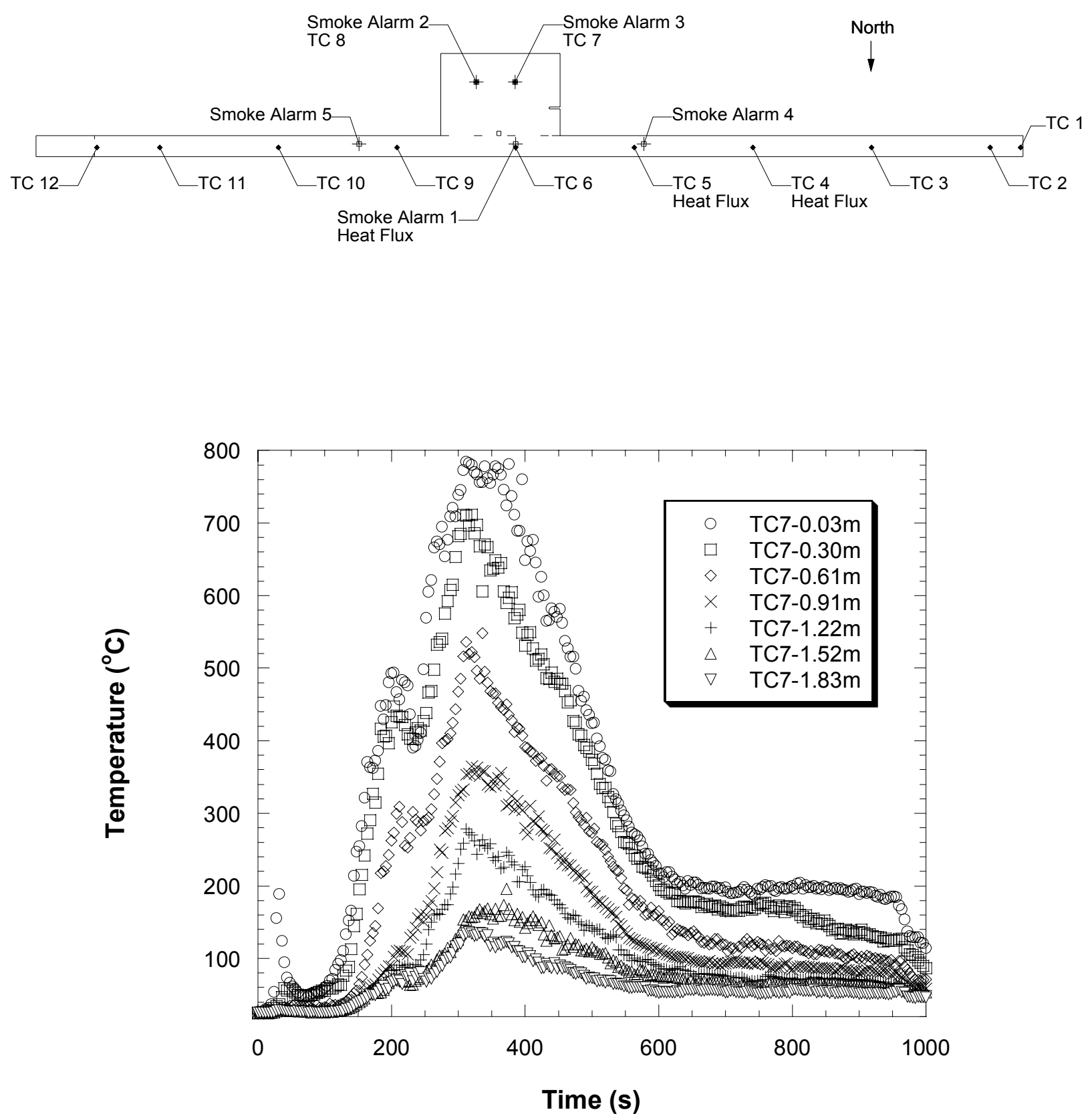

Figure 35 Experiment 2, day room temperatures, west side near ignition, TC array 7 

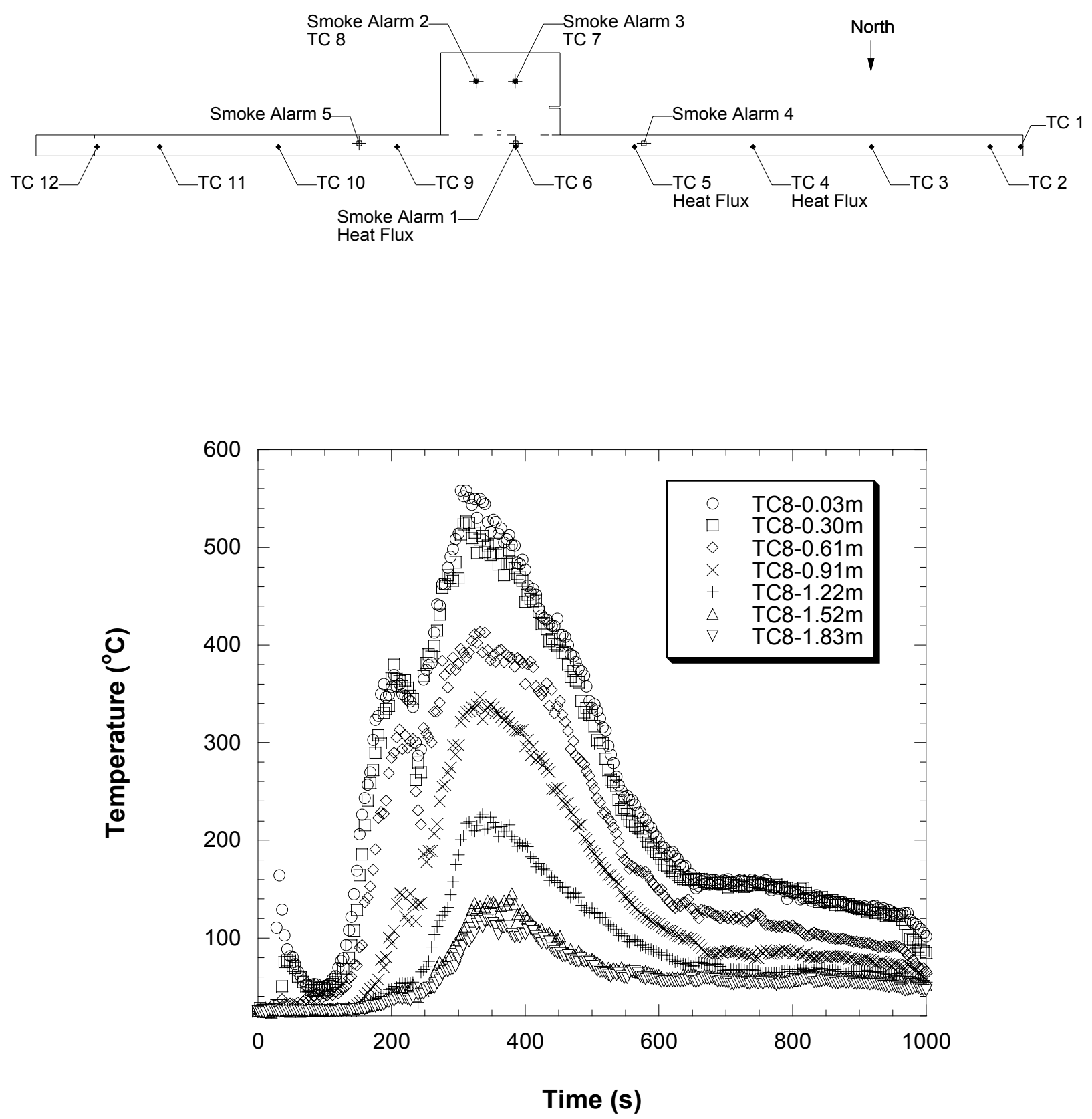

Figure 36 Experiment 2, dayroom temperature, east side, TC array 8 

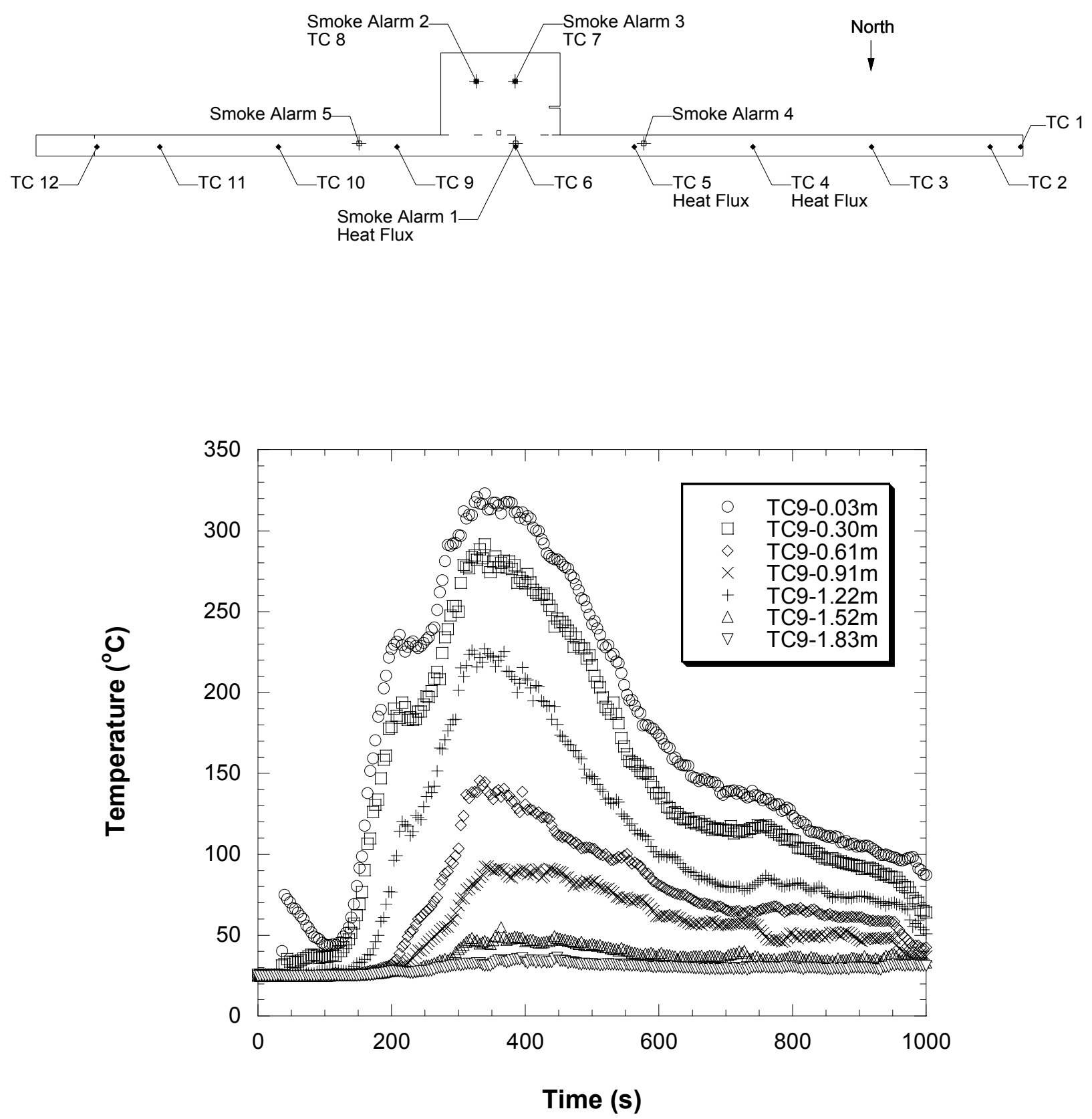

Figure 37 Experiment 2, corridor temperatures, TC array 9 

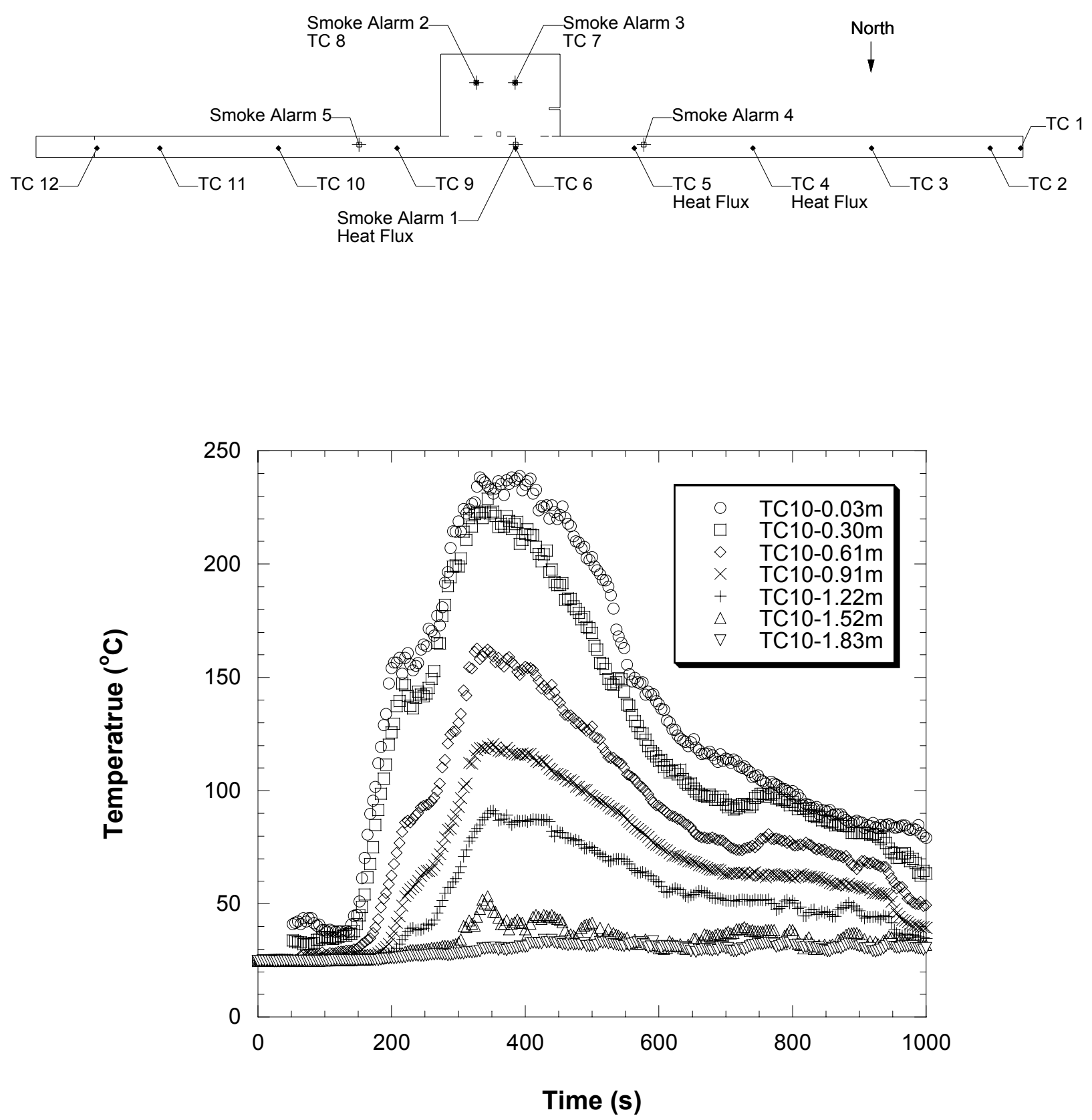

Figure 38 Experiment 2, corridor temperatures, TC array 10 

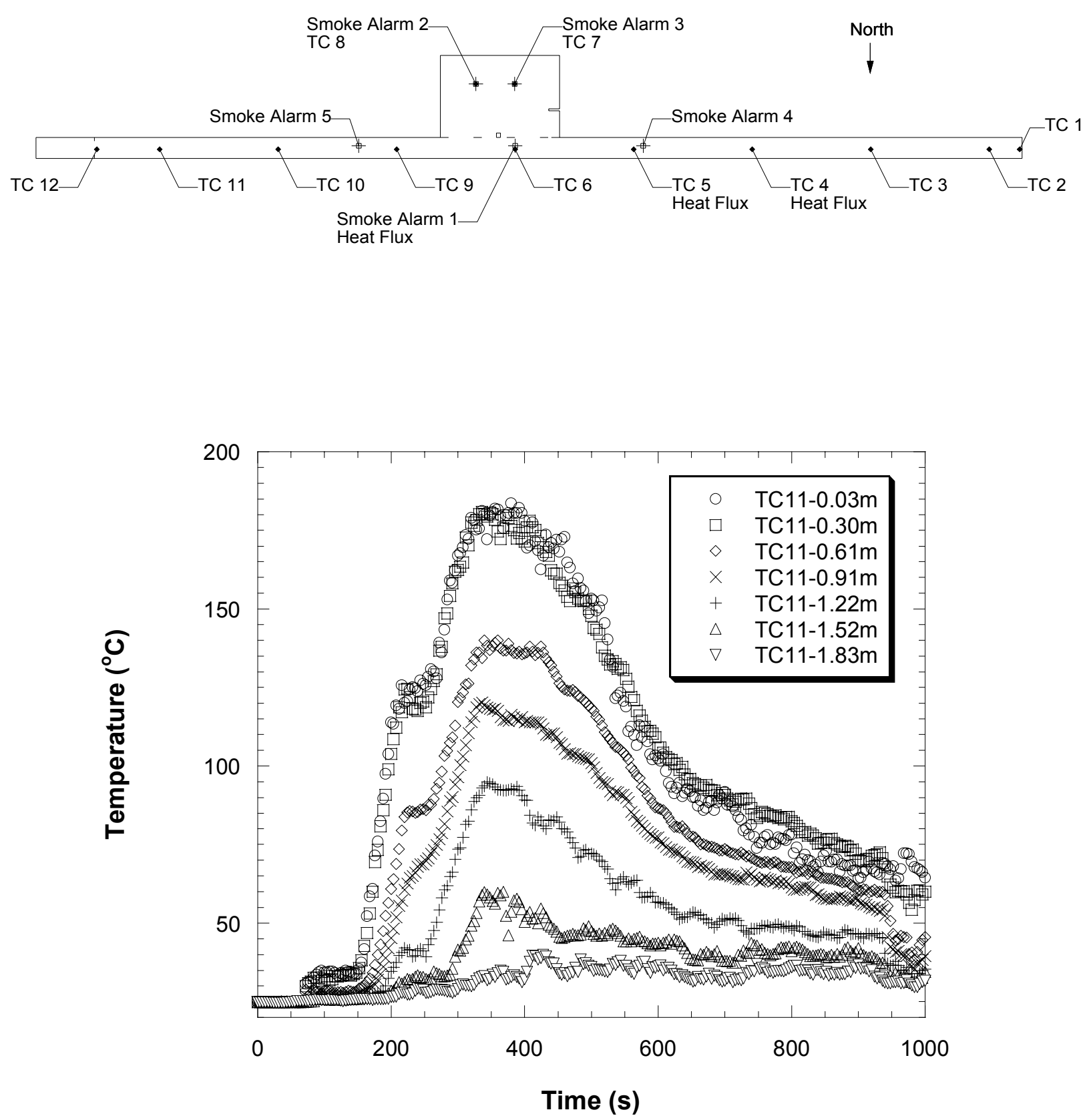

Figure 39 Experiment 2, corridor temperatures, TC array 11 

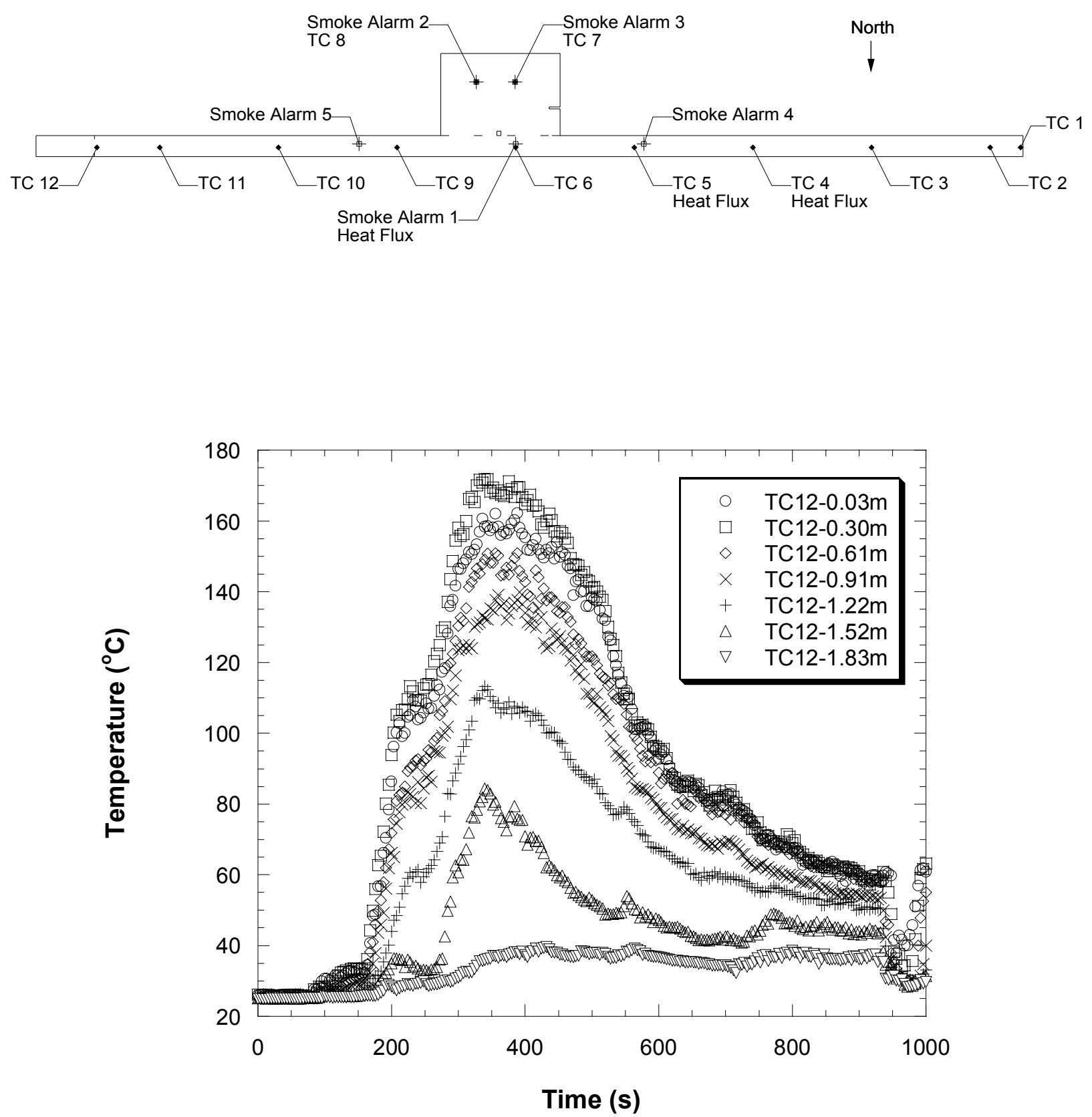

Figure 40 Experiment 2, corridor temperatures, TC array 12 

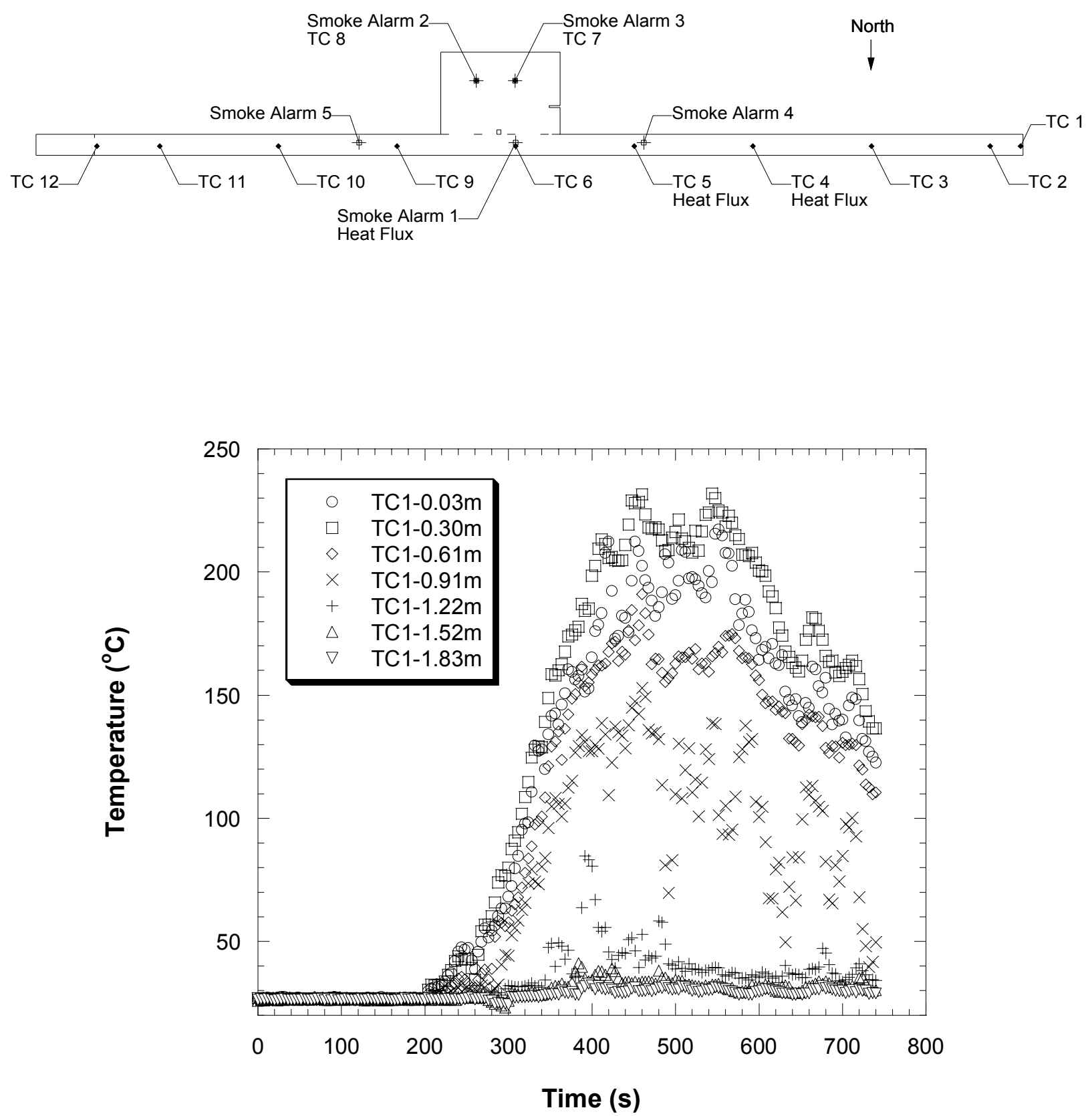

Figure 41 Experiment 3, corridor temperatures, TC array 1 

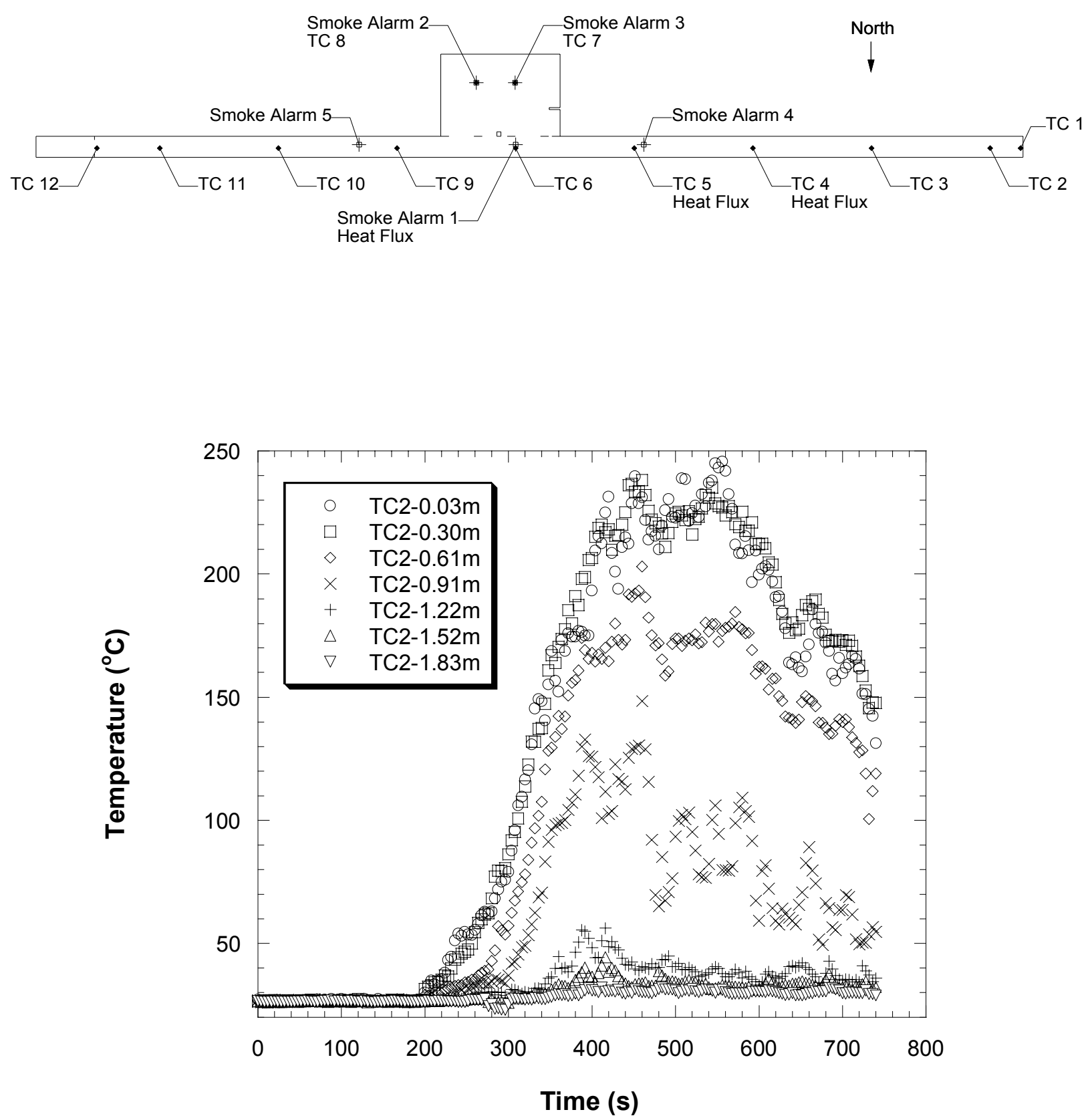

Figure 42 Experiment 3, corridor temperatures, TC array 2 

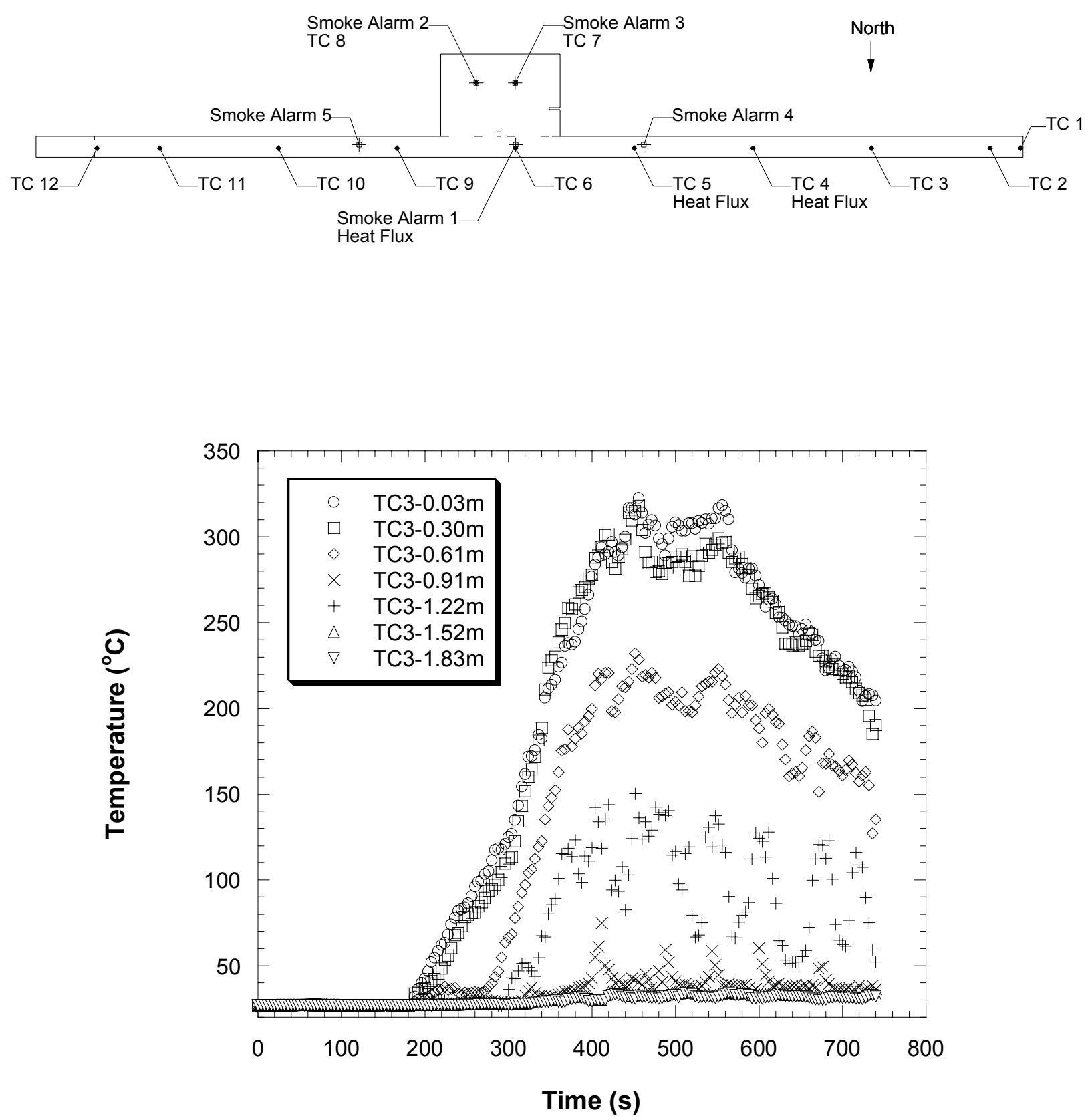

Figure 43 Experiment 3, corridor temperatures, TC array 3 

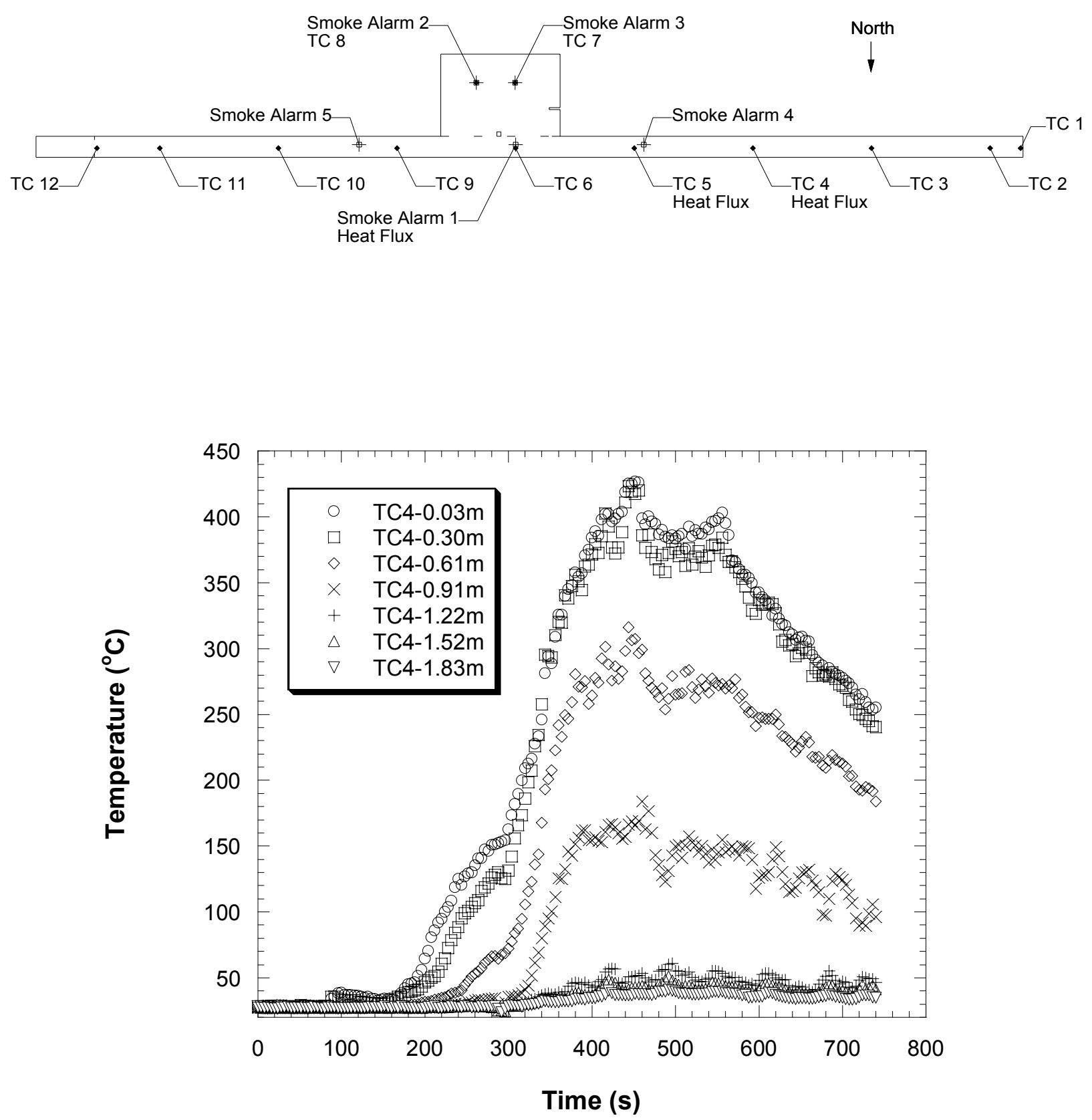

Figure 44 Experiment 3, corridor temperatures, TC array 4 

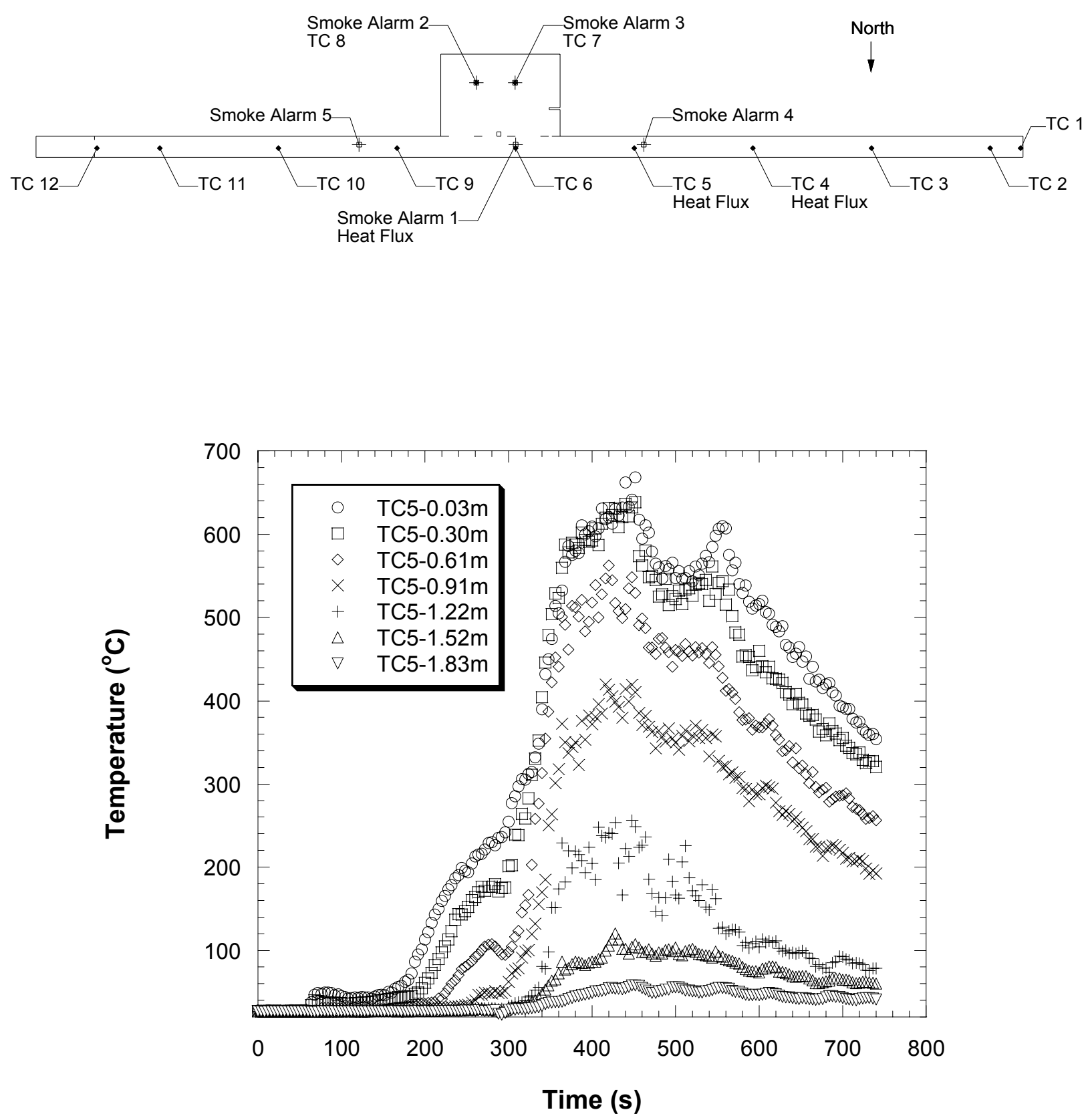

Figure 45 Experiment 3, corridor temperatures, TC array 5 

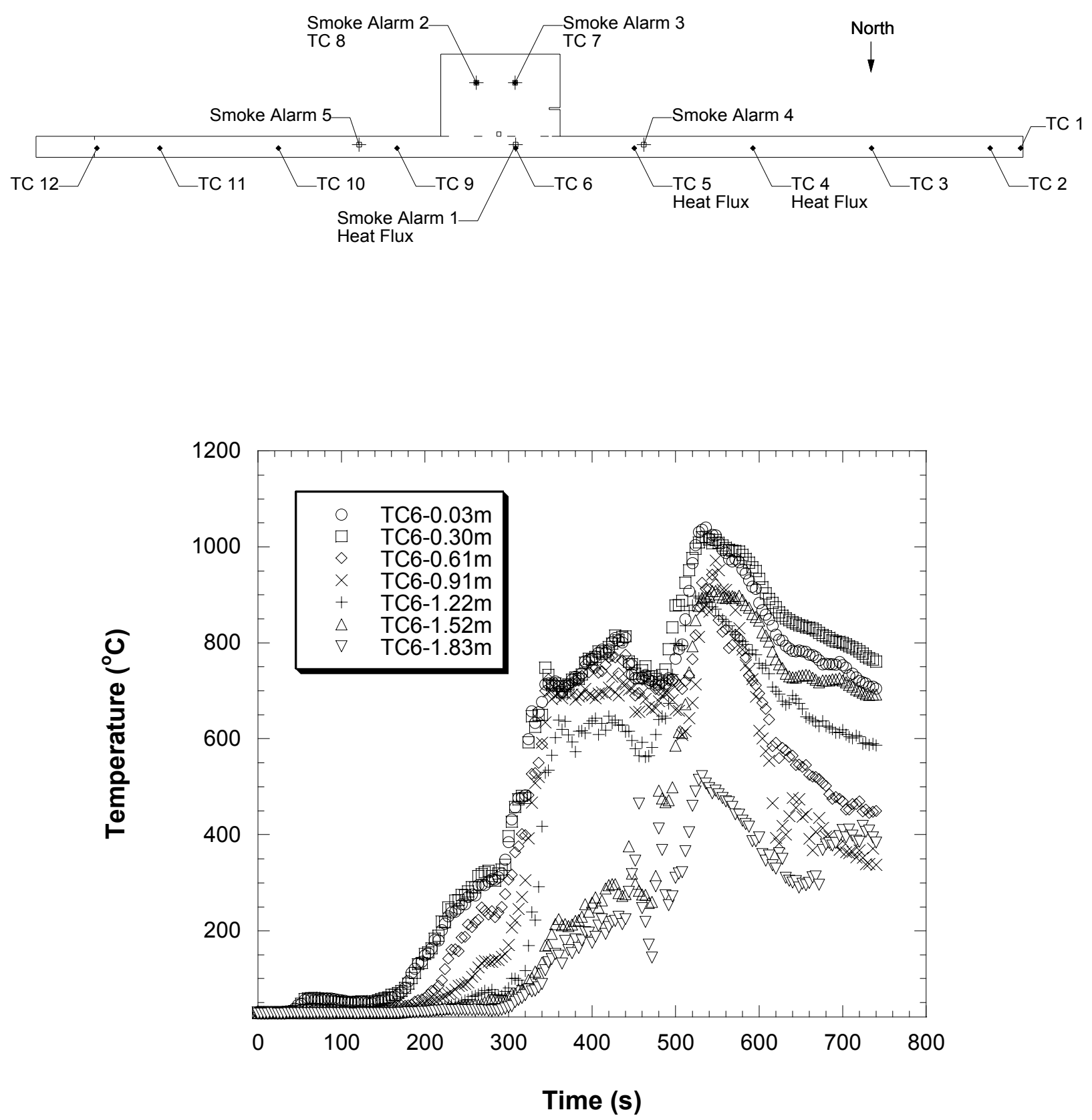

Figure 46 Experiment 3, corridor temperatures, TC array 6 

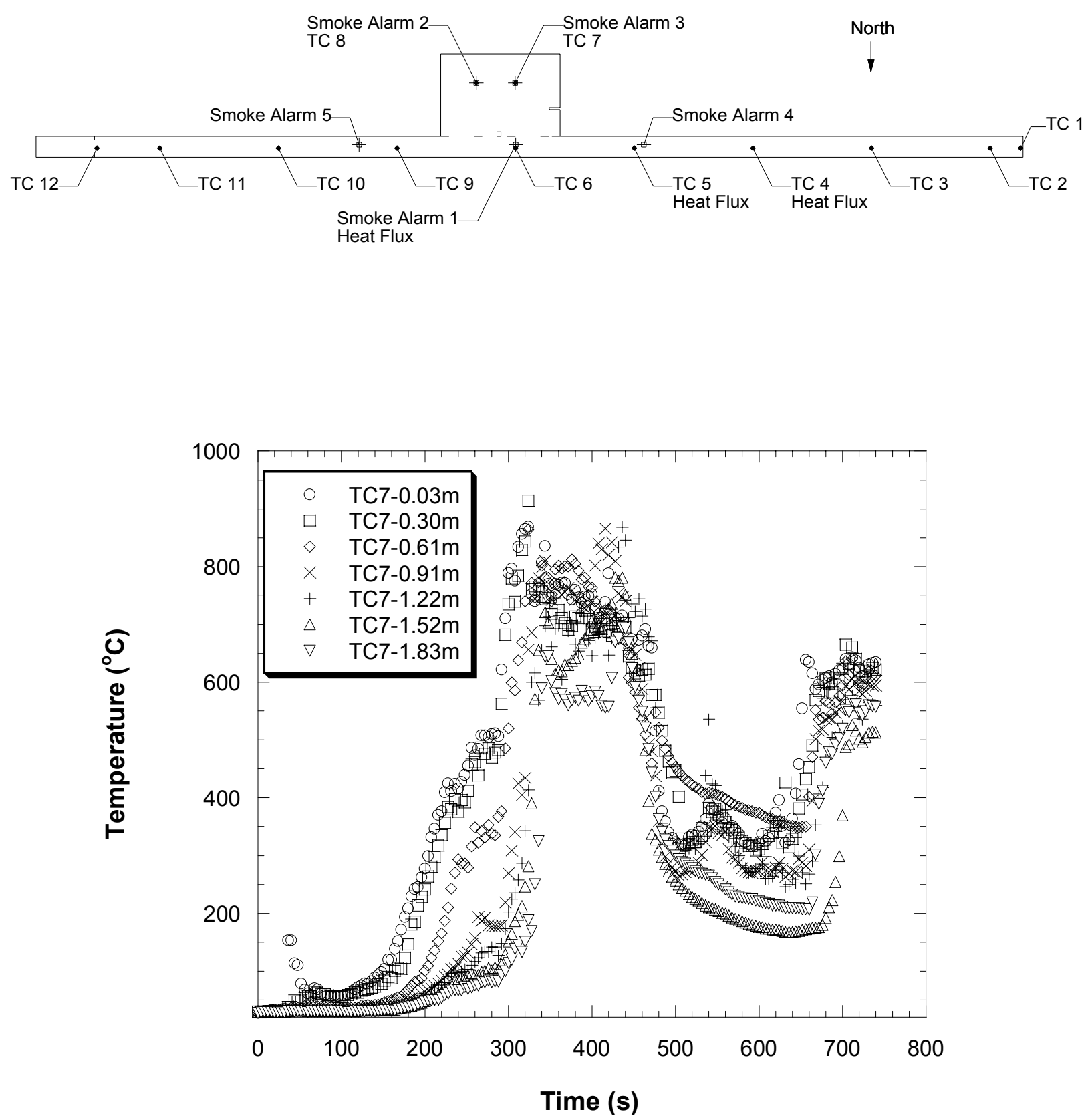

Figure 47 Experiment 3, dayroom temperatures, west side near ignition, TC array 7 

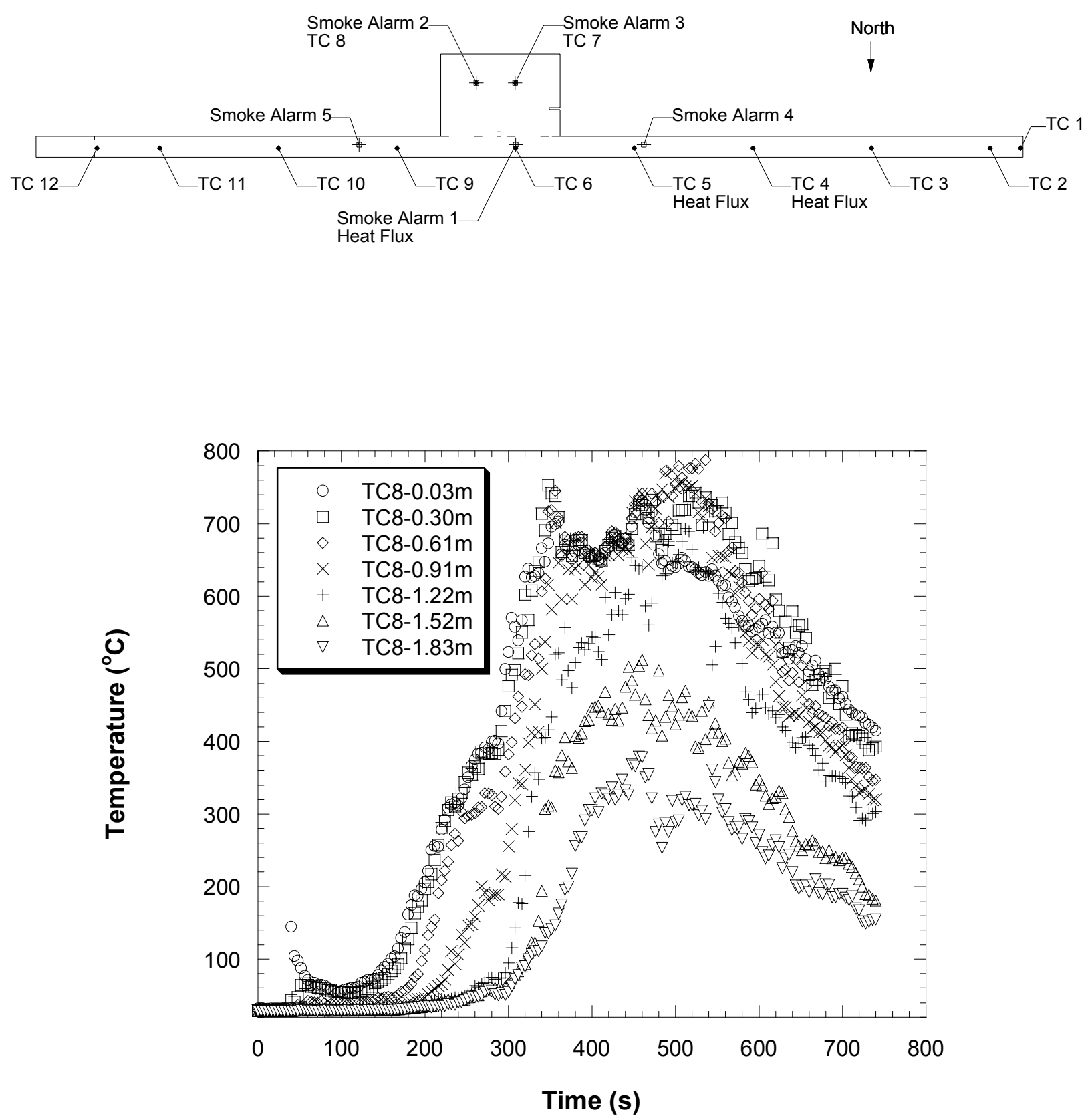

Figure 48 Experiment 3, dayroom temperatures, east side, TC array 8 

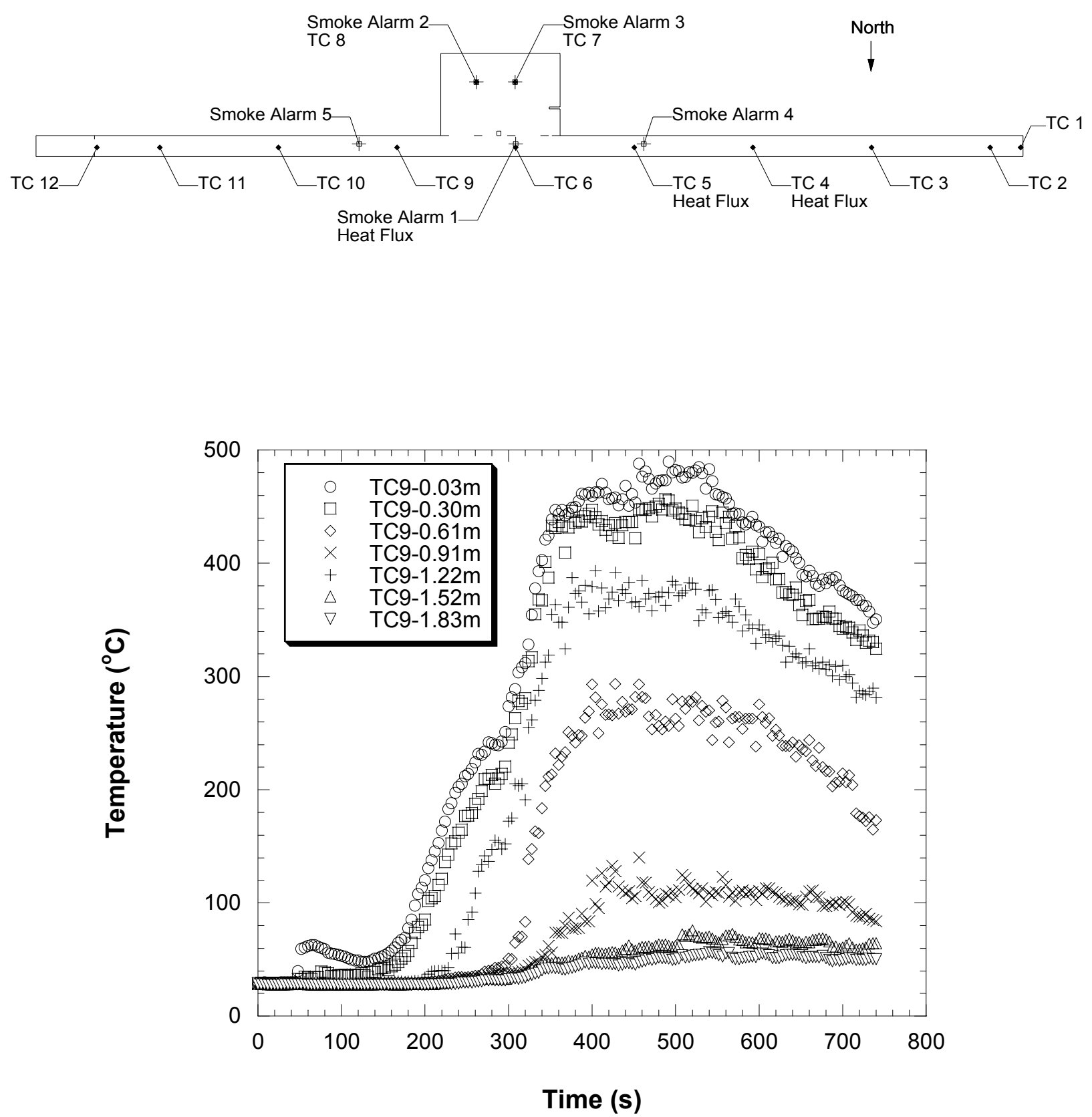

Figure 49 Experiment 3, corridor temperatures, TC array 9 

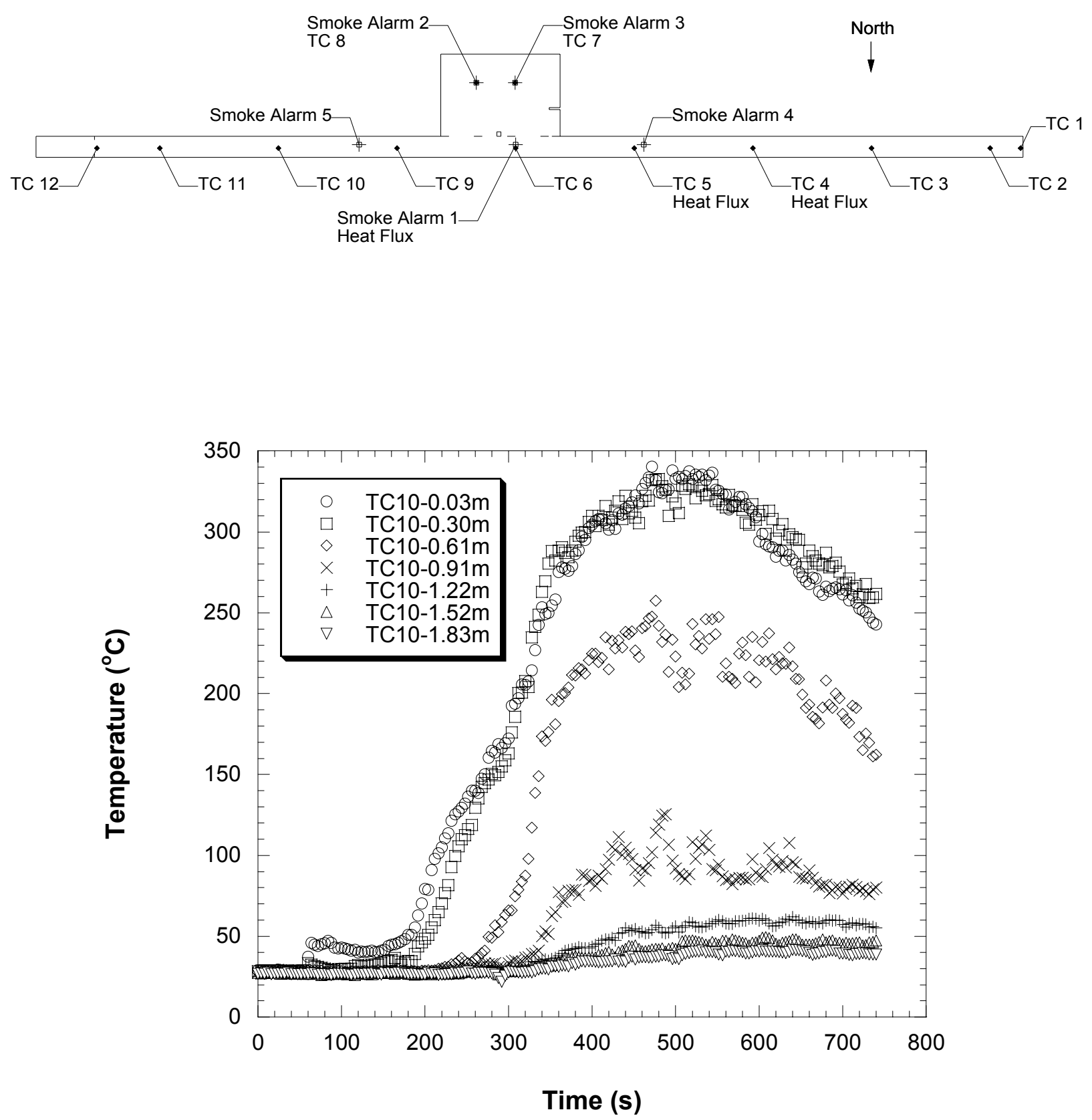

Figure 50 Experiment 3, corridor temperatures, TC array 10 

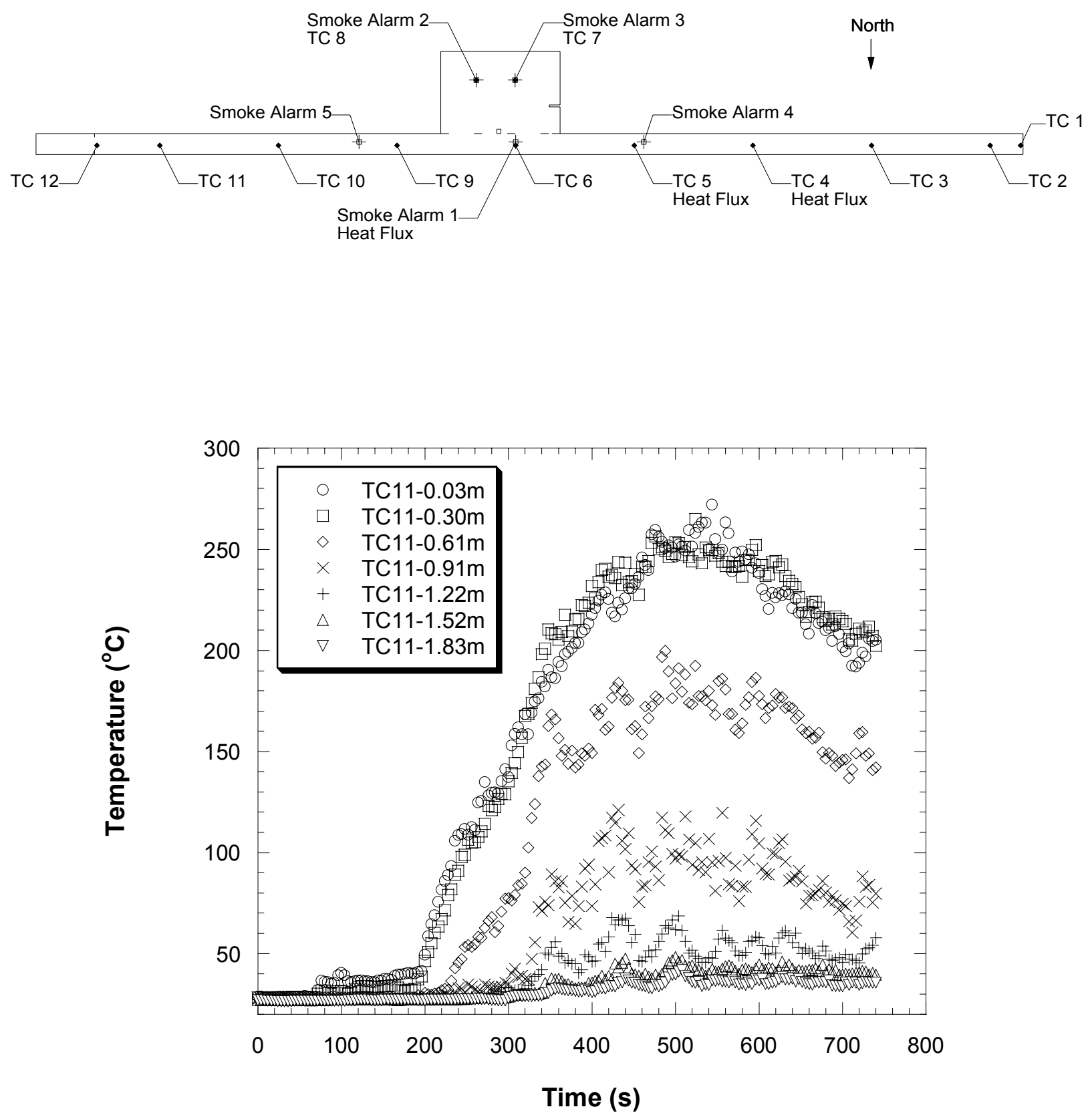

Figure 51 Experiment 3, corridor temperatures, TC array 11 

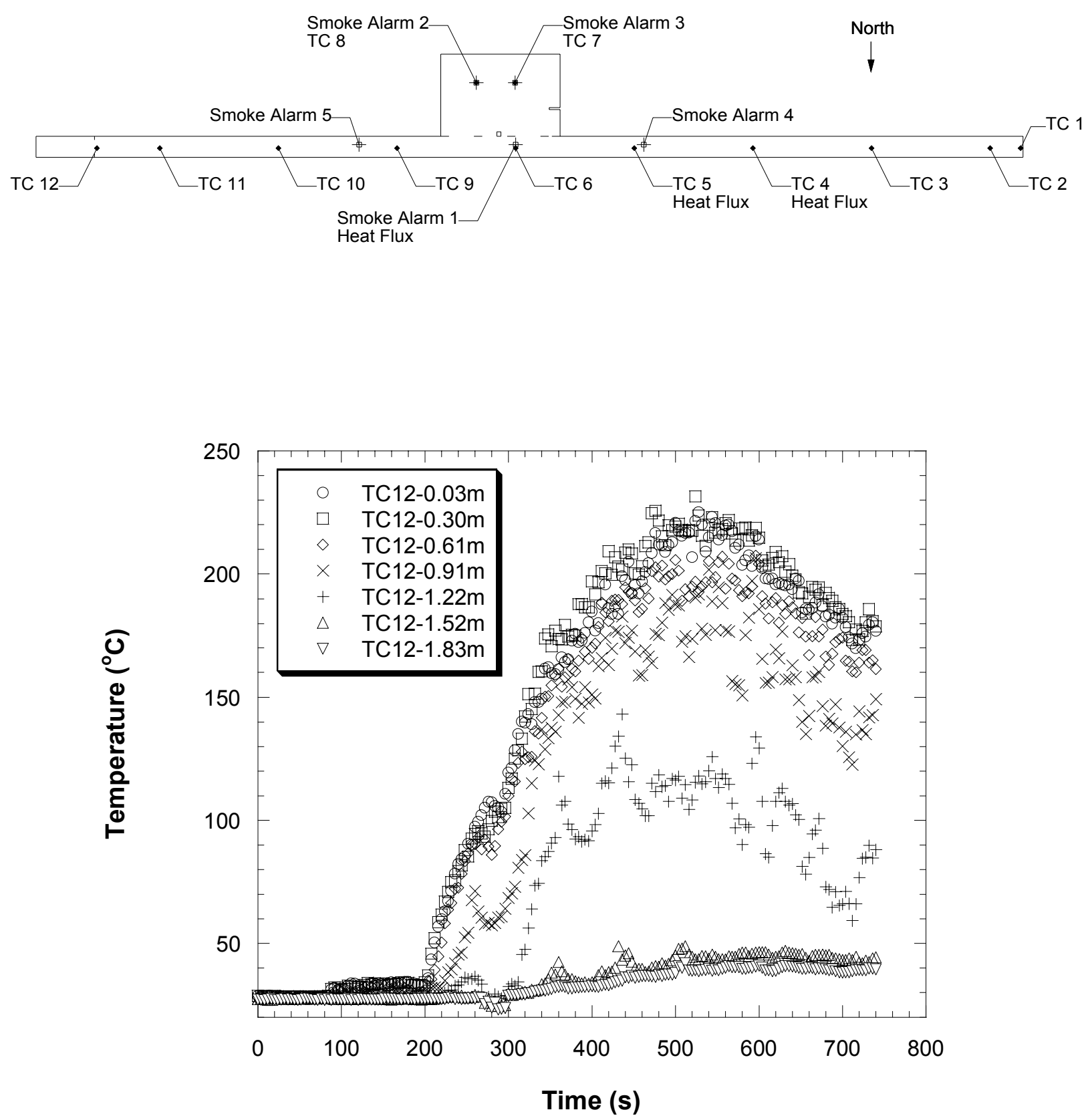

Figure 52 Experiment 3, corridor temperatures, TC array 12 

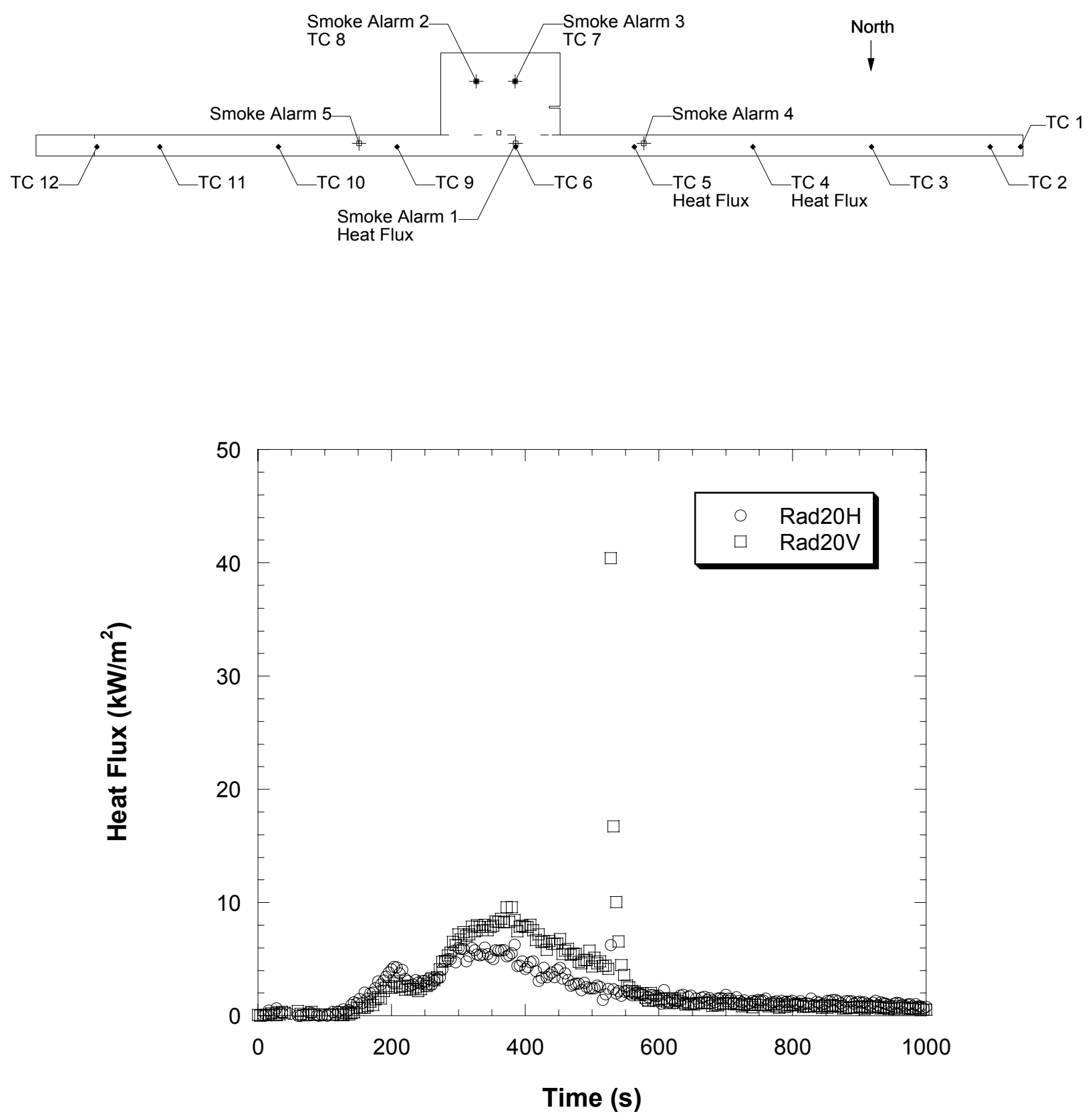

Figure 53 Experiment 2, total heat flux measured adjacent to TC array 6 

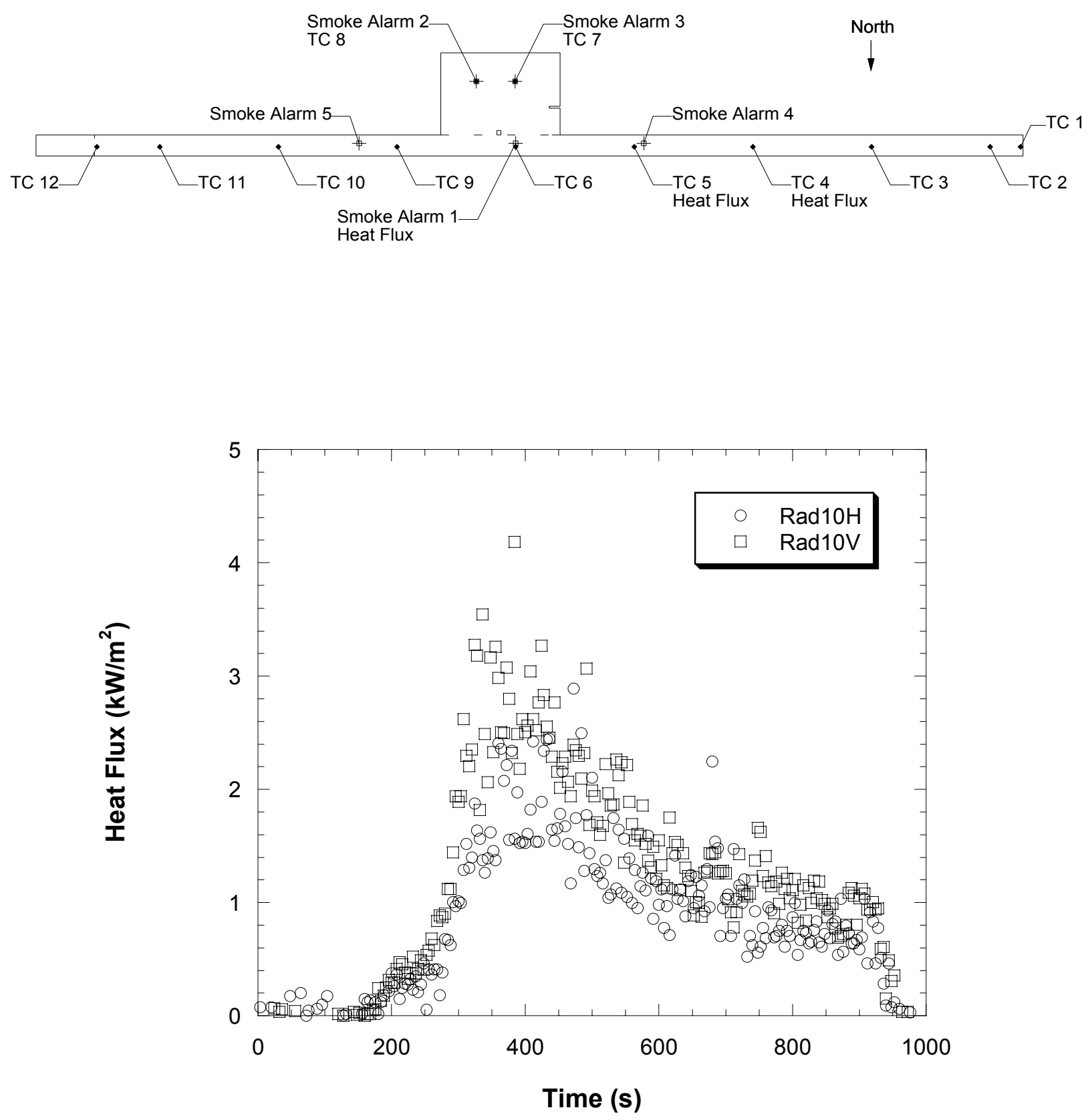

Figure 54 Experiment 2, total heat flux measured adjacent to TC array 5 

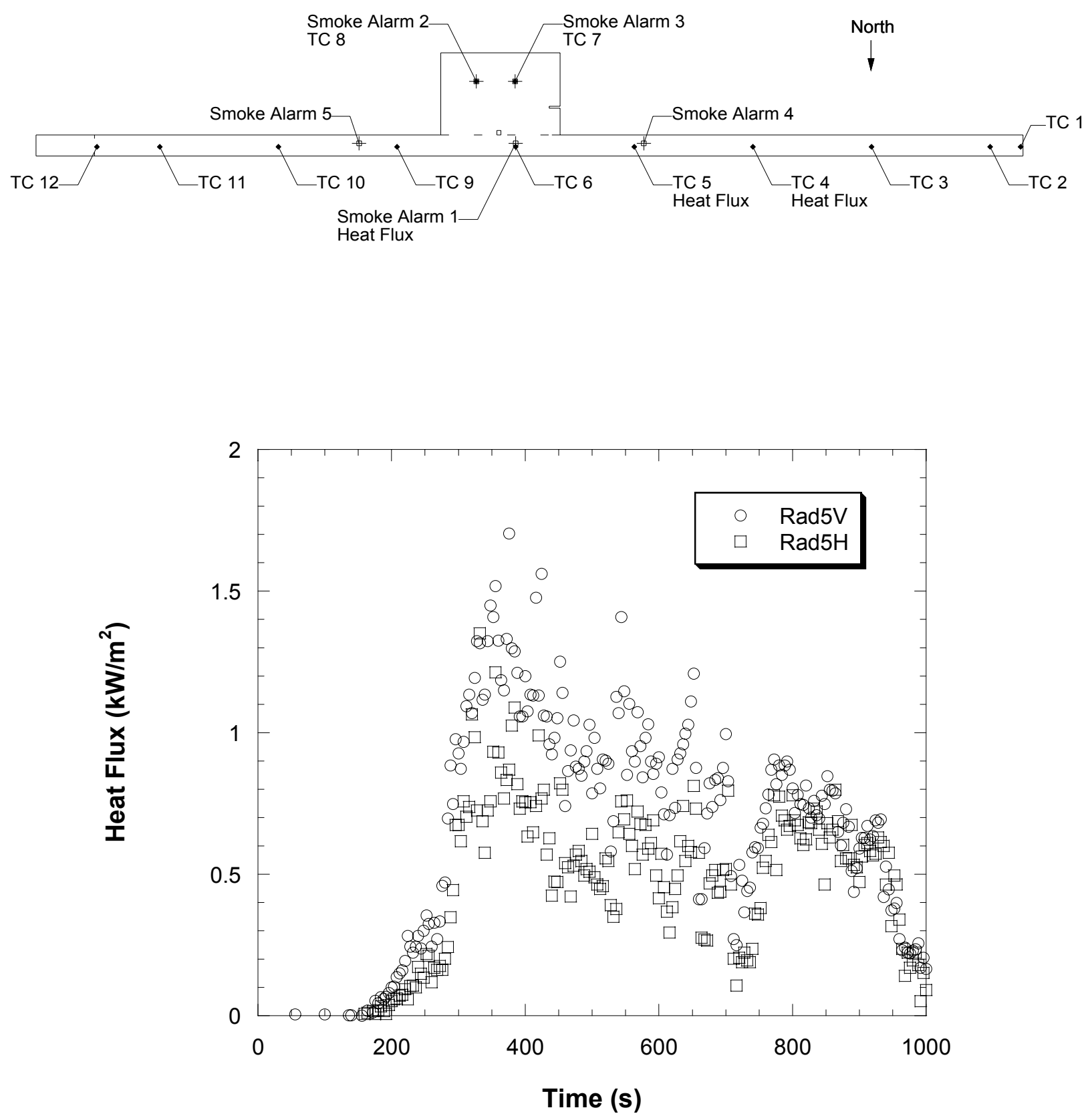

Figure 55 Experiment 2, total heat flux measured adjacent to TC array 4 

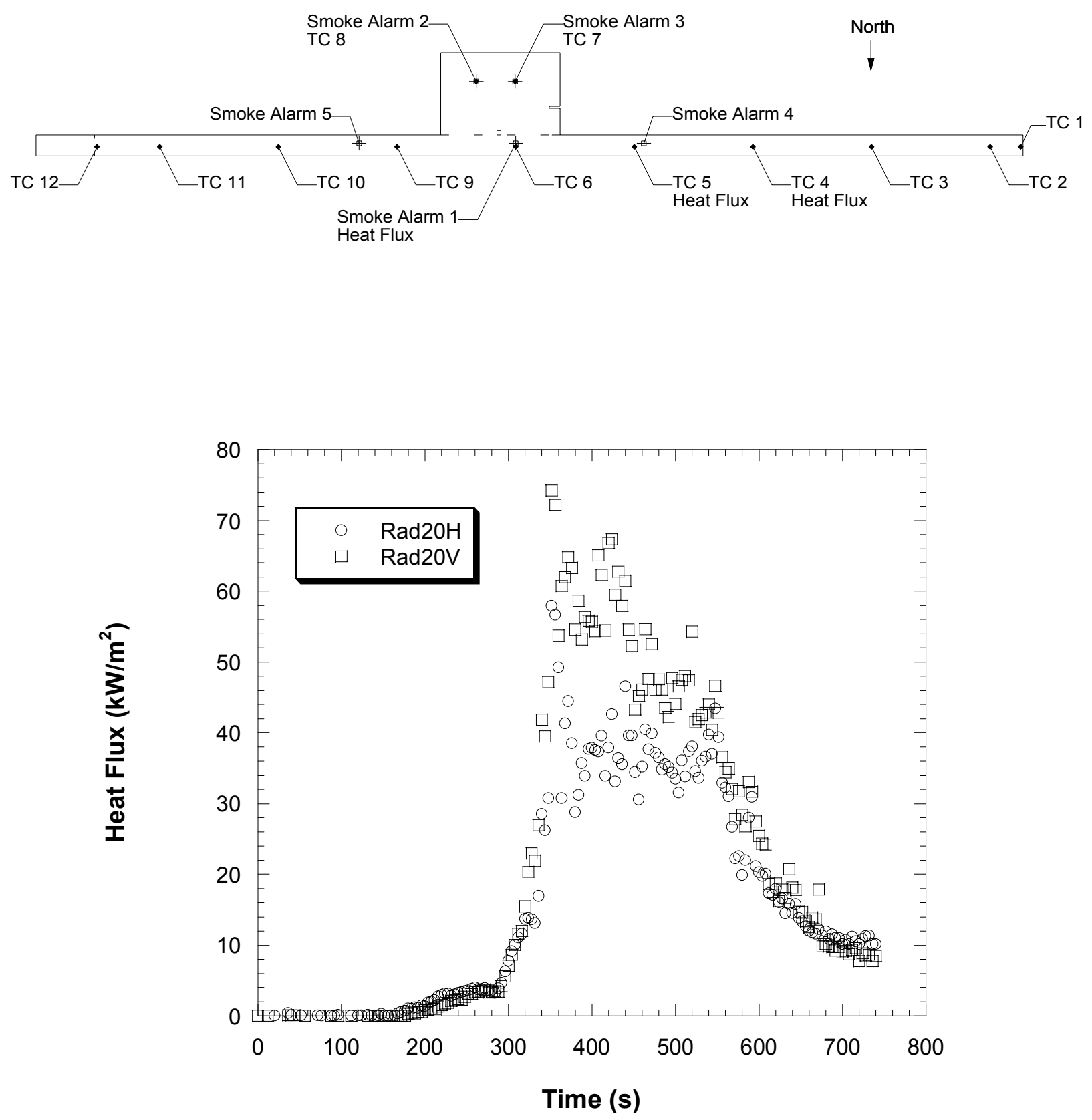

Figure 56 Experiment 3, total heat flux measured adjacent to TC array 6 

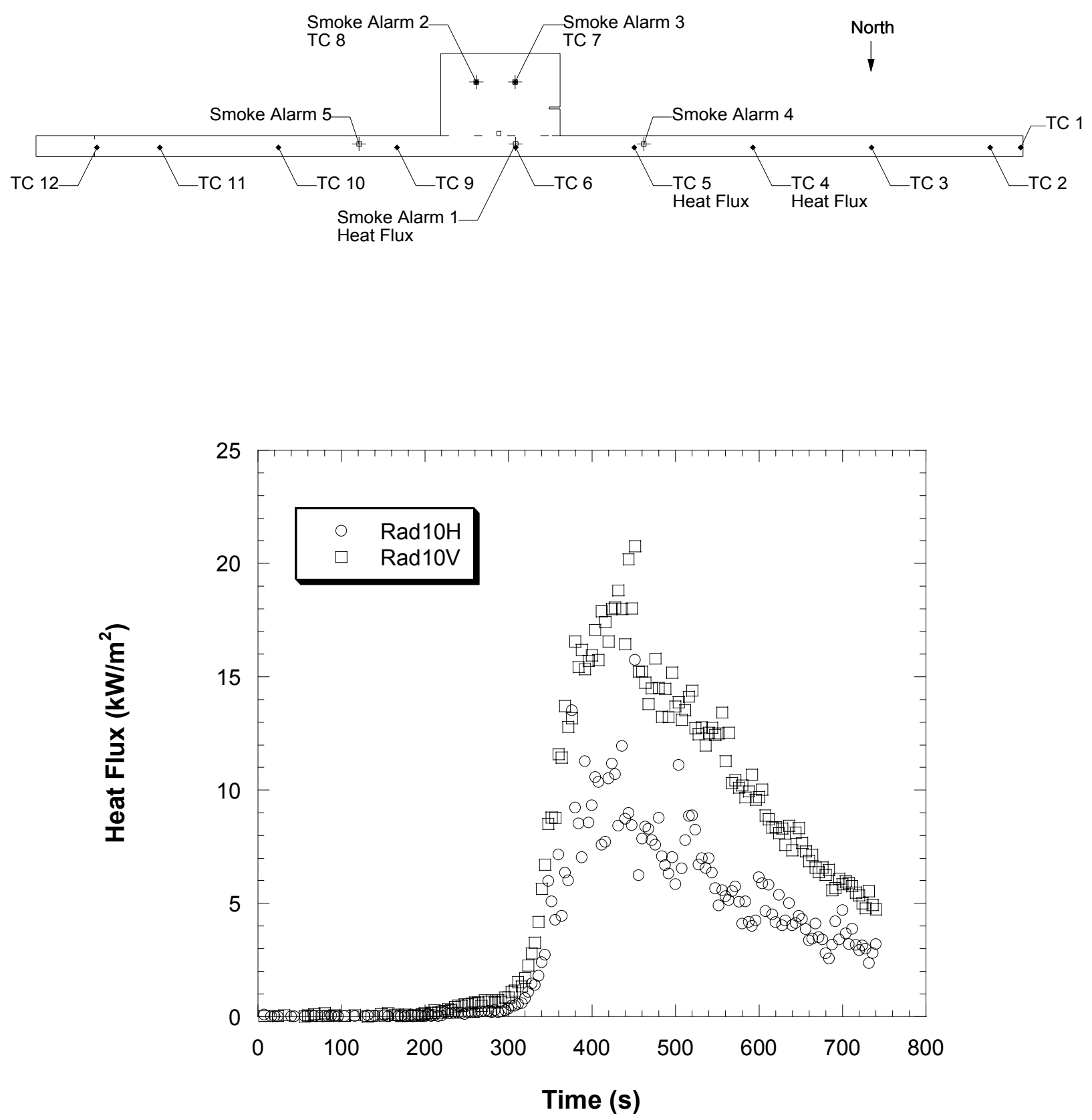

Figure 57 Experiment 3, total heat flux measured adjacent to TC array 5 

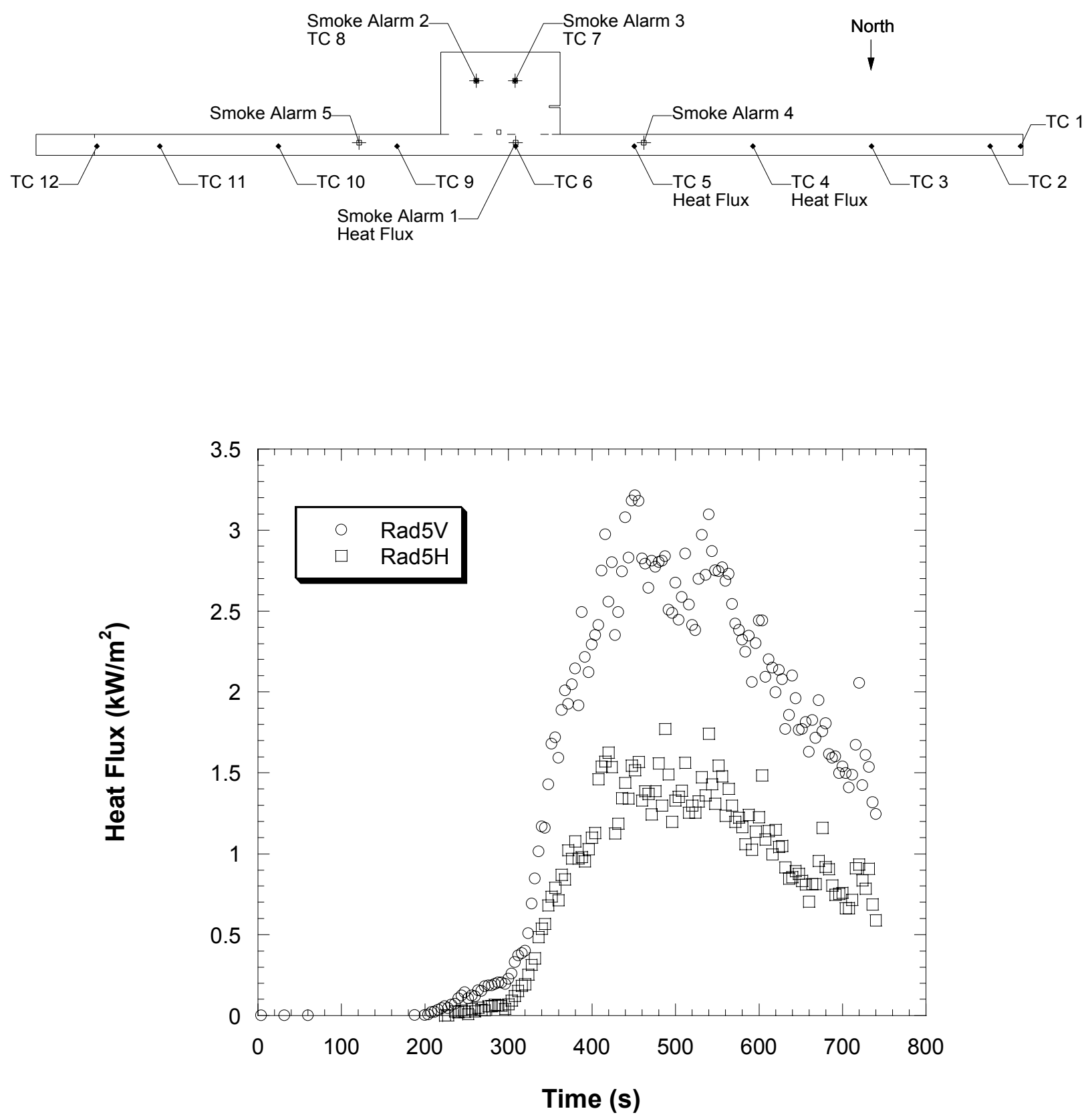

Figure 58 Experiment 3, total heat flux measured adjacent to TC array 4 

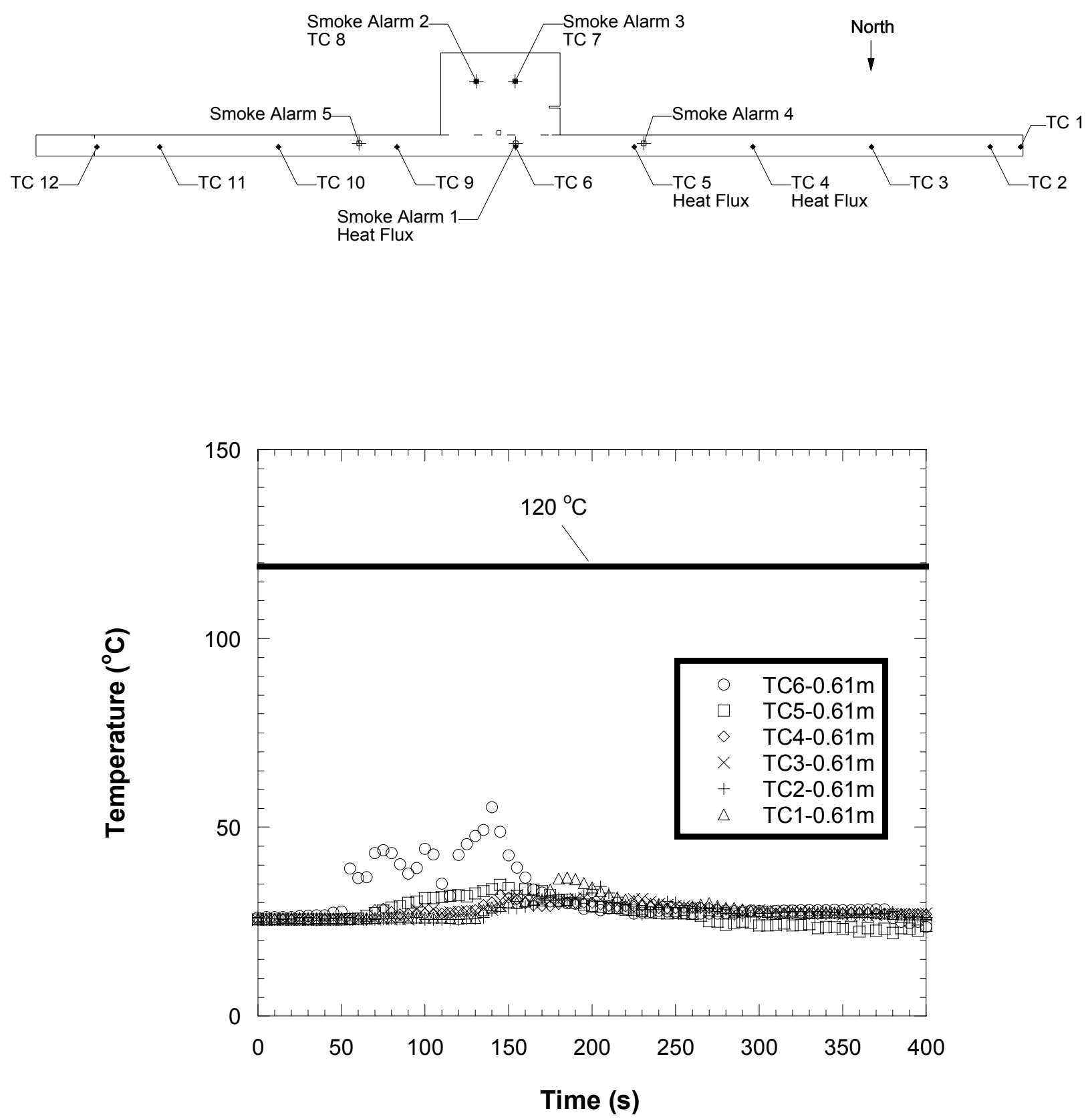

Figure 59 Experiment 1, temperatures in west corridor at $0.61 \mathrm{~m}$ below ceiling 

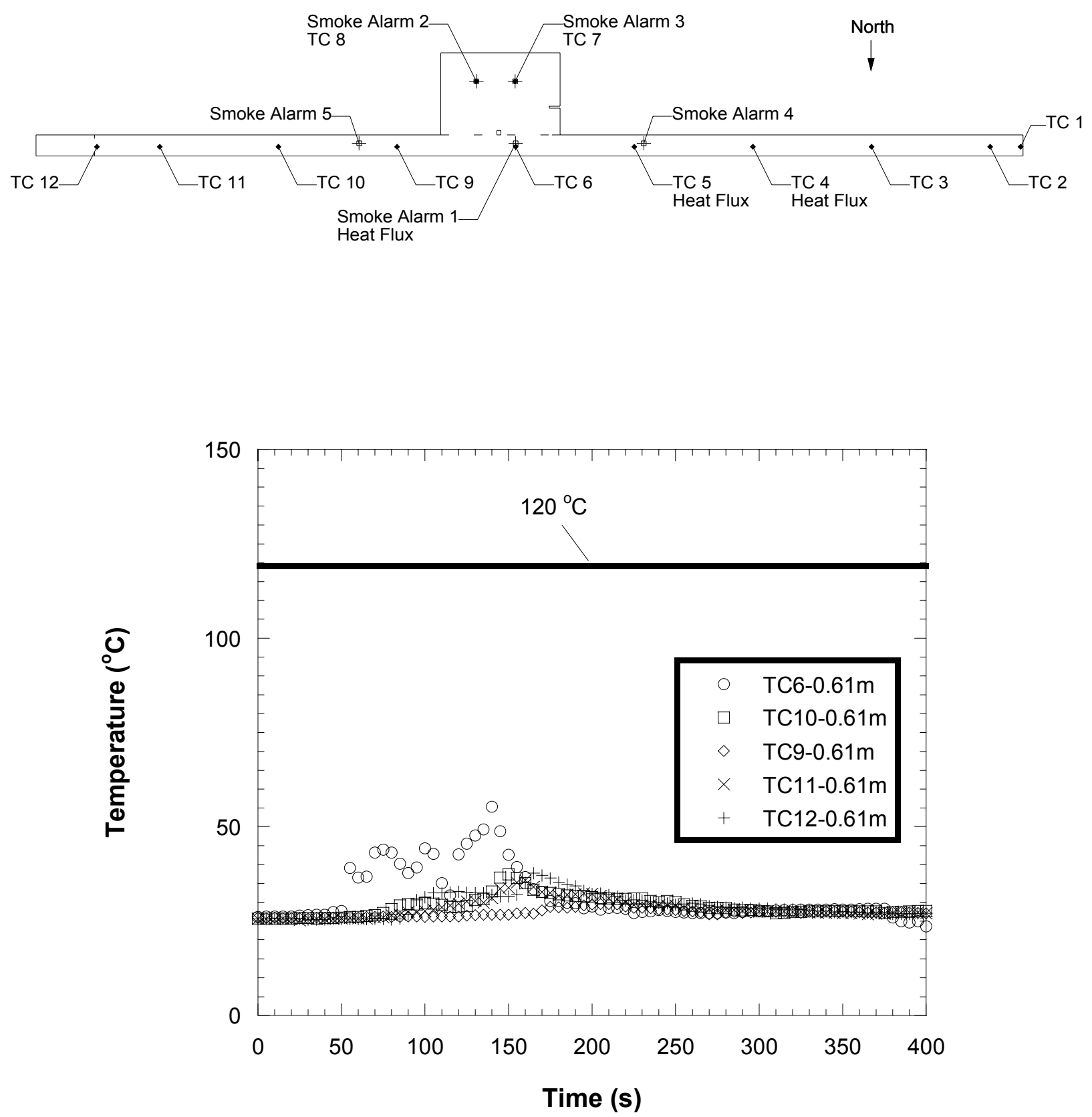

Figure 60 Experiment 1, temperatures in east corridor at $0.61 \mathrm{~m}$ below ceiling 

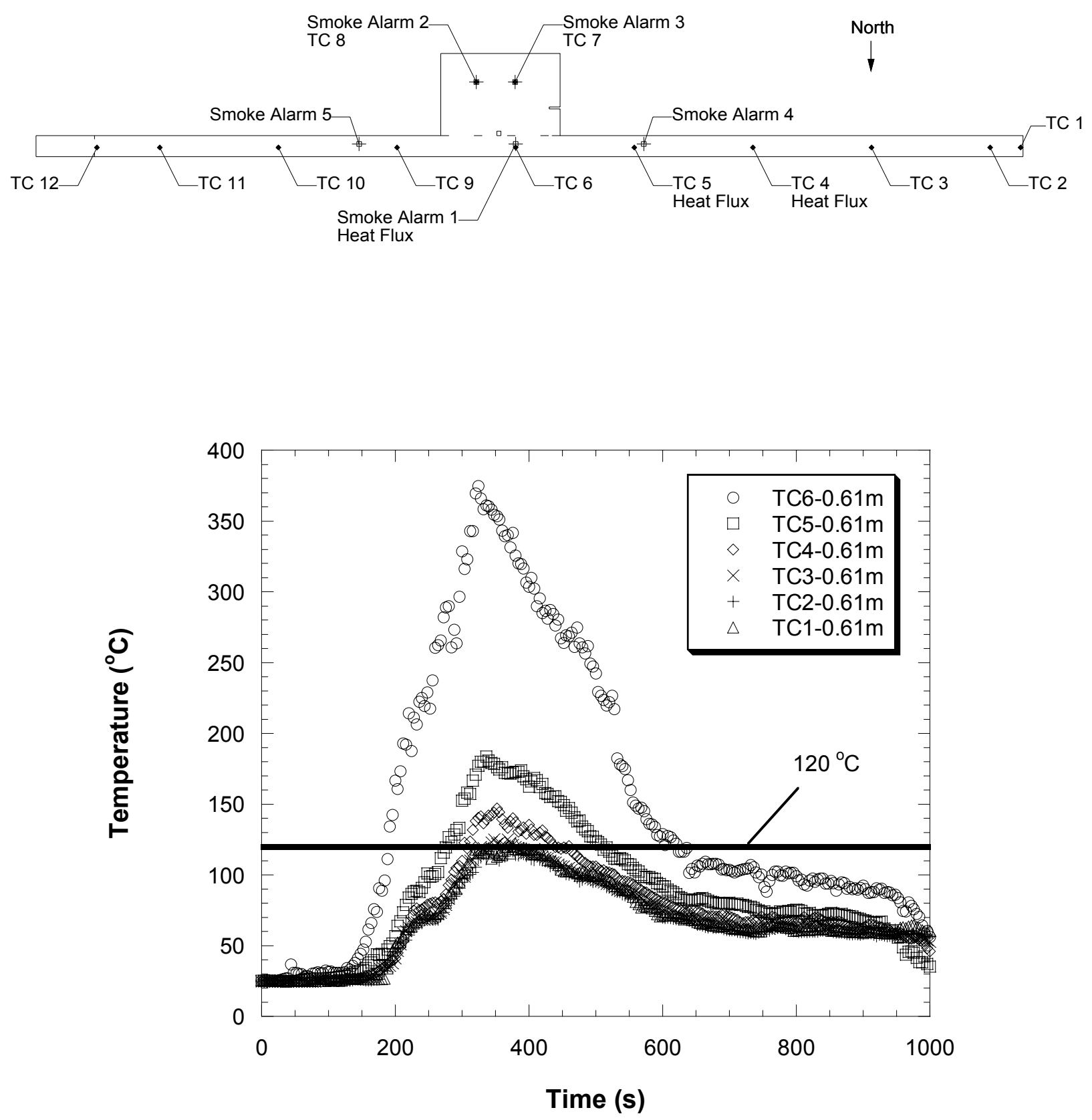

Figure 61 Experiment 2, temperatures in west corridor at $0.61 \mathrm{~m}$ below ceiling 

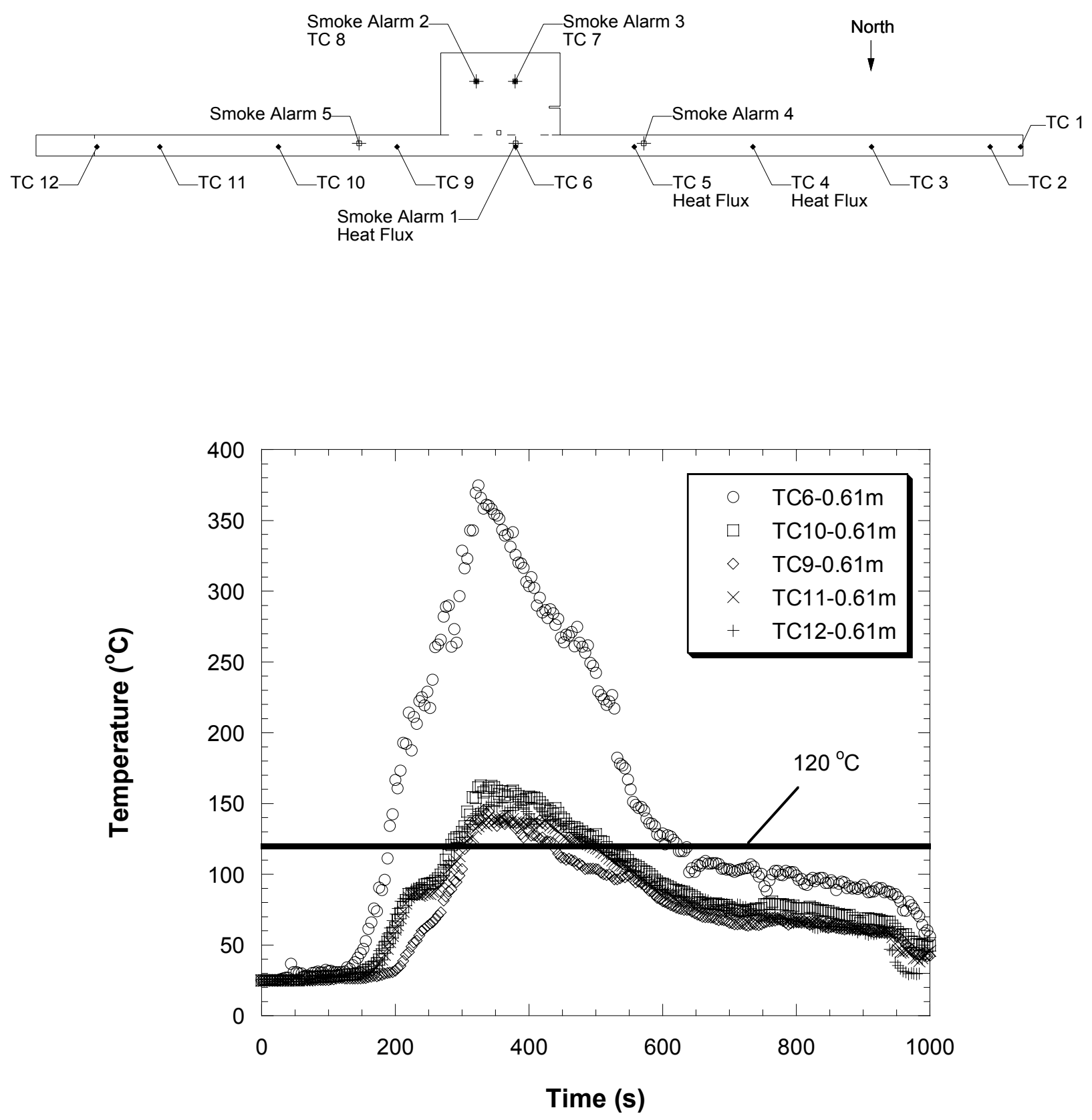

Figure 62 Experiment 2, temperatures in east corridor at $0.61 \mathrm{~m}$ below ceiling 

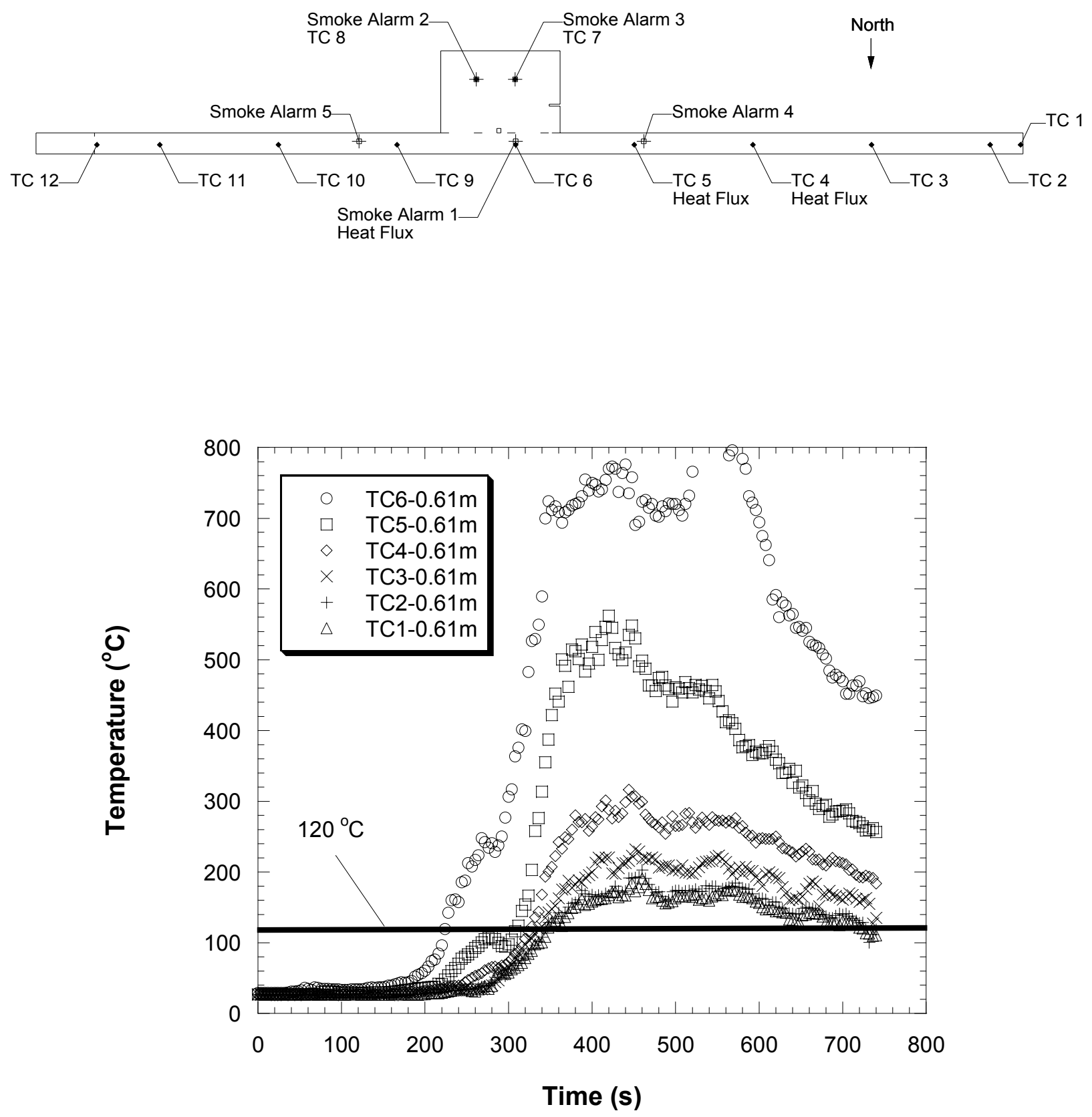

Figure 63 Experiment 3, temperatures in west corridor at $0.61 \mathrm{~m}$ below ceiling 

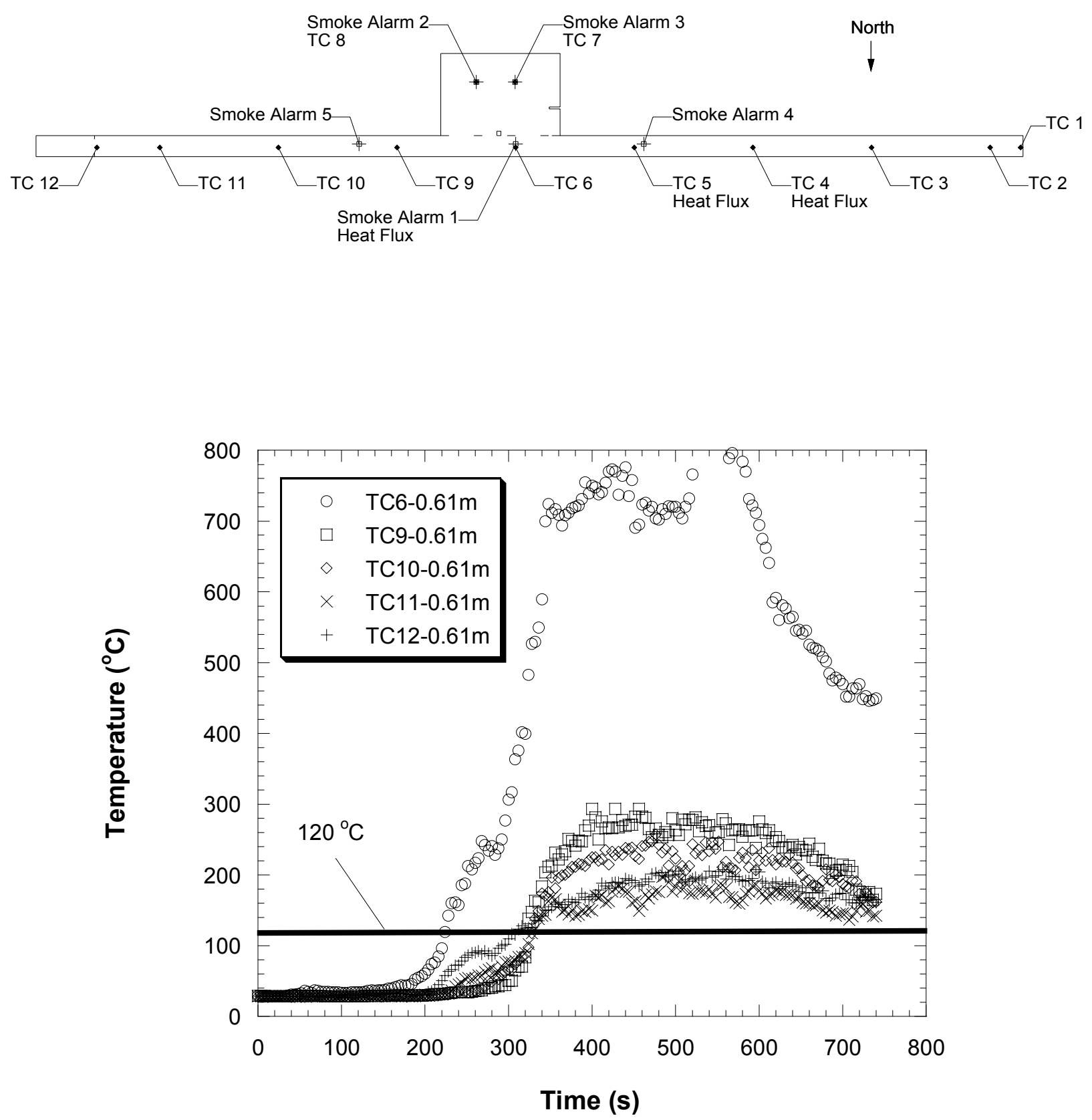

Figure 64 Experiment 3, temperatures in east corridor at $0.61 \mathrm{~m}$ below ceiling 

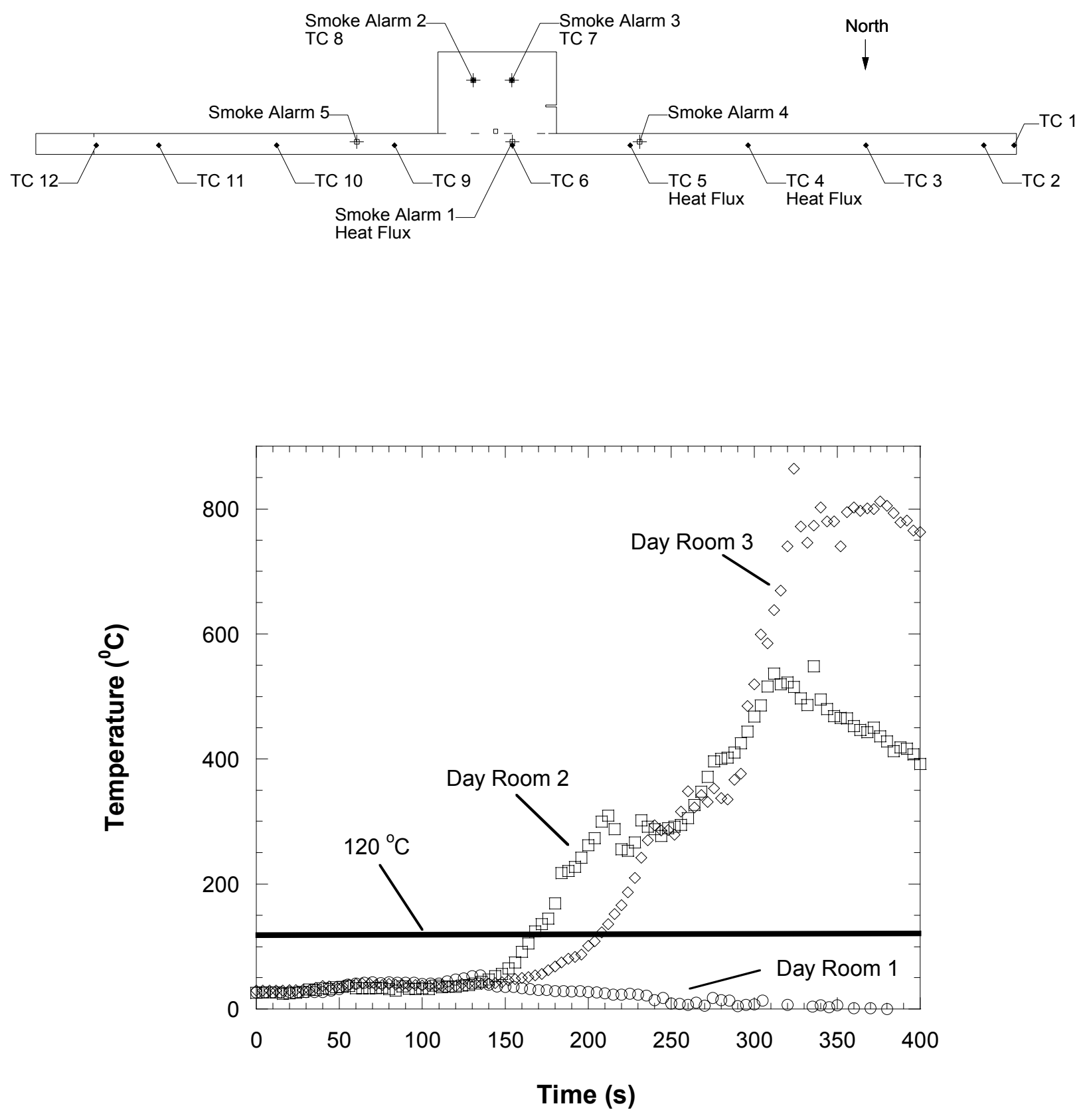

Figure 65 Day room temperature comparisons for experiments 1, 2, and 3 at $0.61 \mathrm{~m}$ below ceiling, TC array 7. 